\title{
Geology and Oil Resources \\ of the Eastern Puente Hills \\ Area, Southern California
}

GEOLOGICAL SURVEY PROFESSIONAL PAPER 420-B
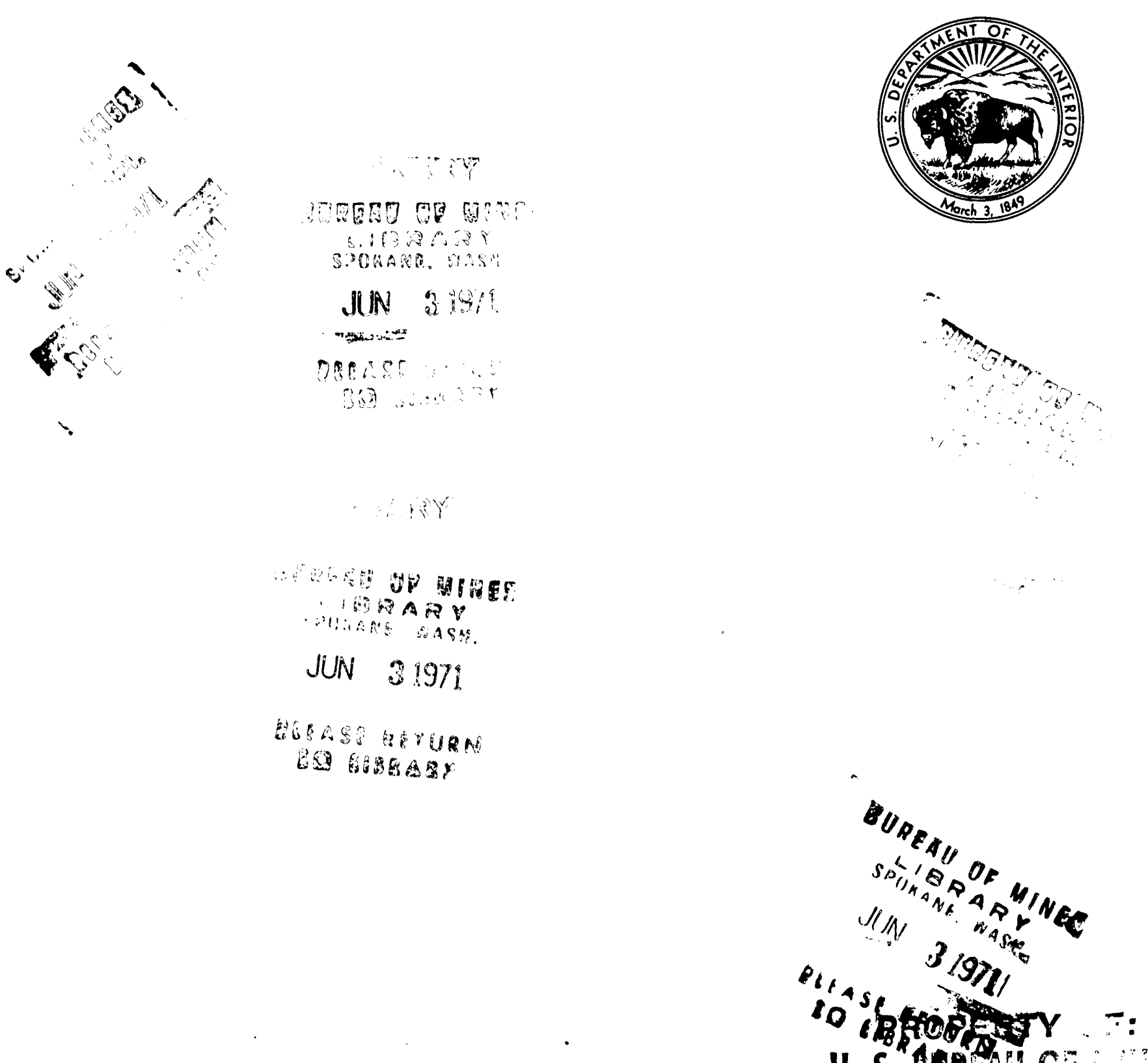

U.S. 169 A 0 ?

DIVISION OF MINERAL RESOURCES 


\section{Geology and Oil Resources of the Eastern Puente Hills}

Area, Southern California

By D. L. DURHAM and R. F. YERKES

GEOLOGY OF THE EASTERN LOS ANGELES BASIN, SOUTHERN CALIFORNIA

GEOLOGICAL SURVEY PROFESIONAL PAPER 420-B

A study of the stratigraphy, structure, and

oil resources of the Prado Dam and

Yorba Linda quadrangles

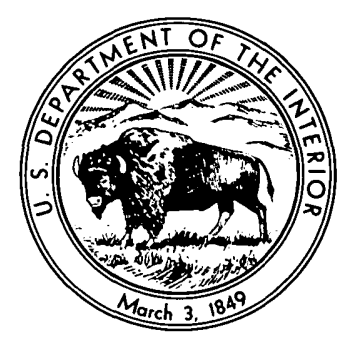

\section{MBRARY}

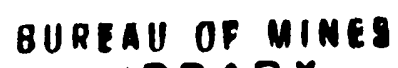

LIBRARY

SPOKANE. WASH.

UN 31971

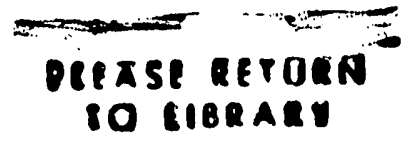

UNITED STATES GOVERNMENT PRINTING OFFICE, WASHINGTON : 1964 
UNITED STATES DEPARTMENT OF THE INTERIOR

STEWART L. UDALL, Secretary

GEOLOGICAL SURVEY

Thomas B. Nolan, Director

For sale by the Superintendent of Documents, U.S. Government Printing Office Washington, D.C., 20402 


\section{ONTENTS}

Abstract.-...

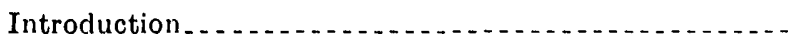

Location of area..........

Purpose of investigation. . .

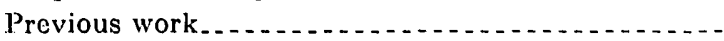

Ficldwork and preparation of report

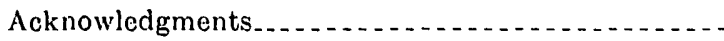

Stratigraphy

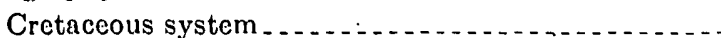

Plutonic rocks.......

Sedimentary rocks.................................

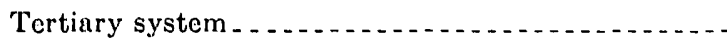

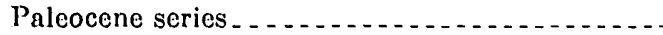

Silverado formation. . .

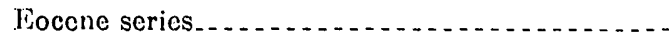

Santiago formation........................

Upper Eocene to lower Miocene series. . . . . . . .

Vaqueros and Sespe formations undiffer-

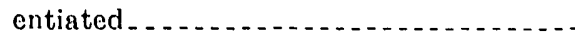

Middle Miocene series.....................

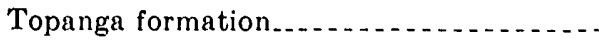
Diamond Bar sand........................

Volcanic rocks associated with the Topanga

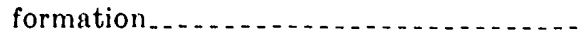

Upper Miocene series......................

Puente formation......................

La Vida member...........................

Soquel member.......................

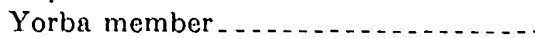

Sycamore Canyon member................

Diabasic intrusive rocks associated with the Puente and older formations........

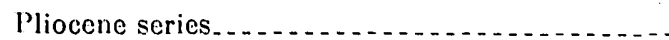

Fernando formation......................

Lower member . .

Upper member

Page
B1
3
3
3
4
5
5
5
5
5
5
6
6
6
6
6
7

7
7
8
8
10
10
11
11
12
18
24
24

Stratigraphy-Continued Page

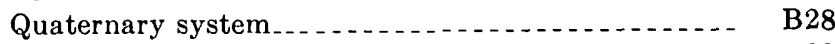

Pleistocene series _...................... 28

Unnamed strata of Pleistocene age...... 28

La Habra formation. . . . . . . . . . . . . 28

Pleistocene to Recent series _........ 30

Older alluvium . . . . .

Younger alluvium ................... 31

Structure $\ldots \ldots \ldots . . . \ldots 31$

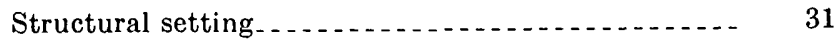

Whittier fault zone.......................... 31

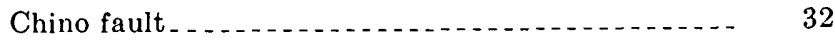

Structural features north of the Whittier fault zone and west of the Chino fault.

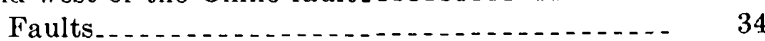

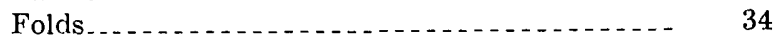

Structural features northeast of the eastern Puente

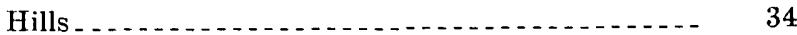

Structural features south of the eastern Puente

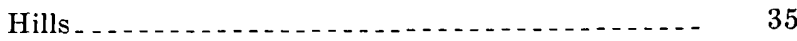

Physiography

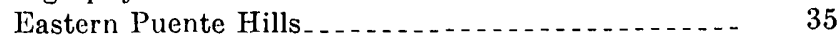

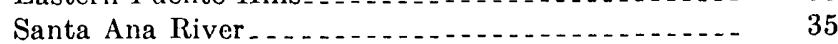

Area south of the Puente Hills . . . 36

Whittier fault zone.

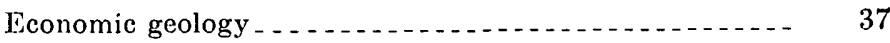

Brea-Olinda oil field

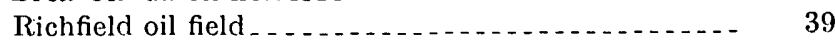

East Coyote oil field

Yorba Linda oil field . . . . . . . . . . . . . . . 40

Esperanza oil field $\ldots \ldots \ldots \ldots$

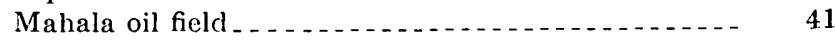

Chino-Soquel oil field

Summary of oil occurrence.

Outlook for future development $\ldots \ldots$

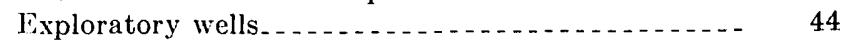

Fossil localities

San Juan tunnel $\ldots \ldots \ldots$

References cited 59

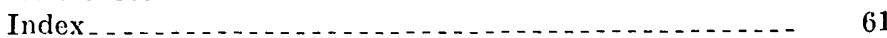

\section{ILLUSTRATIONS}

[Plates are in pocket]

Plate 1. Geologic map of Prado Dam and Yorba Linda quadrangles, Los Angeles, Orange, Riverside, and San Bernardino Counties. California.

2. Composite stratigraphic section for the eastern Puente Hills area.

3. Geologic sections $A-A^{\prime}, B-B^{\prime}, C-C^{\prime}$, and $D-D^{\prime}$, Prado Dam and Yorba Linda quadrangles, California.

4. Geologic sections $E-E^{\prime}, F-F^{\prime}, G-G^{\prime}$, and $H-H^{\prime}$, Prado Dam and Yorba Linda quadrangles, California.

2. Acrial view of the eastern Puente Hills area 
FiguRE 3. Sandstone and conglomerate of the Vaqueros and Sespe formations undifferentiated...

4. View northward across the Santa Ana River toward Scully Hill

5. Pebbly sandstone of the Topanga formation

6. Siltstone of the La Vida member of the Puente formation

7. Sandstone unit at the base of the Soquel member of the Puente formation

8. Siltstone and thin sandstone beds of the Yorba member of the Puente formation

9. Thick-bedded sandstone in siltstone of the Yorba member of the Puente formation

10. White pebbly sandstone of the Sycamore Canyon member of the Puente formation

11. Vertical beds of pebbly sandstone and mudstone of the Sycamore Canyon member of the Puente formation....

12. Basal conglomerate of the La Habra formation

13. Aerial view southeastward along the Whittier fault zone southeast of the Horseshoe Bend of the Santa Ana River . . .

14. Aerial view southeastward along the Whittier fault zone southeast of Carbon Canyon

15. Exposure of the Chino fault.

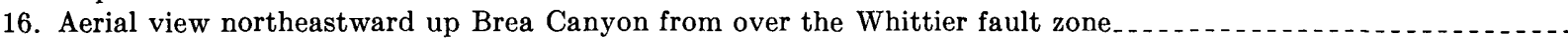

17. Correlation chart of the producing zones in the oil fields in the eastern Puente Hills area.

18. Strata of the Sycamore Canyon member of the Puente formation exposed at the working face of the San Juan tunnel.

19. Geologic structure section along the San Juan tunnel

20. Strata of the Sycamore Canyon member of the Puente formation exposed in the San Juan tunnel............

21. Sample of the Sycamore Canyon member of the Puente formation from the San Juan tunnel.

\section{TABLES}

TABLE 1. Stratigraphic distribution of Foraminifera from the Puente and Fernando formations in the eastern Puente Hills area

2. Production and reserves of oil fields in the eastern Puente Hills area

3. Oil produced in 1957 from members of the Puente and Fernando formations in oil fields in the eastern Puente Hills area

4. Exploratory wells and selected oil-producing wells drilled in the eastern Puente Hills area before June 30, 1958.

5. Fossil localities in the eastern Puente Hills area 


\title{
GEOLOGY OF THE EASTERN LOS ANGELES BASIN, SOUTHERN CALIFORNIA \\ GEOLOGY AND OIL RESOURGES OF THE EASTERN PUENTE HILLS AREA, SOUTHERN CALIFORNIA
}

\author{
By D. L. Durham and R. F. Yerkes
}

\section{A.BSTRACT}

The Puente Hills are 15 to 40 miles southeast of downtown Lon Angeles, in the northeastern part of the Los Angeles basin. The eastern half of the Puente Hills is covered by the Prado Dam and Yorba Linda 71/2-minute quadrangles. The geology of the Puente Hills is of special interest because the strata exposed there are equivalent to those from which most of the oil is produced in the Los Angeles basin.

The Cenozoic sedimentary rocks in the eastern Puente Hills have a composite maximum thickness of about 27,000 feet comprising 14 stratigraphic units. In the northern and eastern parts of the map area, the sedimentary rocks lie on granitic basement rocks of probable early Iate Cretaceous age. The base of the sedimentary section has not been penetrated by wells drilled in the western and southern parts of the map area.

A sequence of marine and nonmarine conglomerate and sandstone beds assigned to the Silverado formation of Paleocene age is exposed south of the Puente Hills in the northern Santa Ana Mountains, where it uncomformably overlies marine strata of Late Cretaceous age. A well drilled near the southeast corner of the Prado Dam quadrangle penetrated about 1,170 feet into the Silverado formation, but this formation and older strata are not known to occur either at the surface or in the subsurface in the Puente Hills. Just south of the Puente Hills, in the northernmost Santa Ana Mountains, the exposed Silverado formation is overlain discomformably by a sequence of marine strata about $\mathbf{7 7 0}$ feet thick, which are assigned to the Santiago formation of middle Eocene age. Strata overlying granitic rocks and tentatively assigned to the Santiago formation were penetrated in several wells drilled in the eastern Puente Hills.

Marine and nonmarine strata assigned to the Vaqueros and Sespe formations undifferentiated, of late Eocene to early Miocene age, crop out in the southern part of the Prado Dam quadrangle, where they discomformably overlie the Santiago formation. The Vasqueros and Sespe formations overlap the Santiago formation in the subsurface to the north, where they overlie granitic basement rocks. The Vaqueros and Sespe formations, undifferentiated, have a maximum thickness of 2,000 feet in the eastern Puente Hills.

The Topanga formation is exposed in the southern part of the Prado Dam quadrangle, where it disconformably overlies the Vaqueros and Sespe formations undifferentiated. In the map area, the Topanga formation has a maximum thickness of 3,300 feet and contains the Turritella ocoyana fauna of middle Miocene age. It consists of sandstone, pebbly sandstone, and generally subordinate amounts of siltstone.
Andesitic and basaltic flows as much as 200 feet thick overlie the Topanga formation in the subsurface at some places in the Yorba Linda quadrangle. These volcanic rocks are in turn overlain at some places in the same area by the Diamond Bar sand of the Topanga formation. Neither the volcanic rocks nor the Diamond Bar sand is present throughout the Yorba Linda quadrangle, and the volcanic rocks are present only in the northwest corner of the Prado Dam quadrangle. The volcanic rocks are of middle Miocene age and are correlated with the El Modeno volcanics, which are exposed south of the Puente Hills; they are tentatively correlated with the Glendora volcanics, which are exposed north of the Puente Hills. The Diamond Bar sand is a local unit that occurs in the Yorba Linda quadrangle in the subsurface only. It consists of unusually dense marine pebbly sandstone, sandstone, and siltstone and has a maximum thickness of 2,500 feet.

The Topanga formation is overlain unconformably by the marine Puente formation of late Miocene age. The Puente formation is divided into four members, in ascending order: the La Vida, Soquel, Yorba, and Sycamore Canyon members. The members interfinger in some areas, and their contacts are commonly gradational. The La Vida member consists chiefly of siltstone and has a maximum thickness in the eastern Puente Hills of 3,800 feet. $A$ bed of basaltic tuff that is 10 to 15 feet thick occurs in the member in the Yorba Linda quadrangle. North of the Whittier fault zone in the Yorba Linda quadrangle, the lower part of the La Vida member and the underlying Topanga formation are intruded by diabase dikes and sills of probable early late Miocene age. Foraminiferal faunas in the La Vida member are characteristic of the Bulimina uvigcrinaformis zone of the middle part of Kleinpell's Mohnian stage of the upper Miocene of California.

The Soquel member consists chiefly of sandstone and is about 200 to 3,100 feet thick. Local unconformities are present at the base of this unit in the northern and eastern parts of the eastern Puente Hills. Sparse foraminiferal faunas from the Soquel member are representative of the Bulimina uvigerinaformis and Bolivina hughesi zones of the middle and upper parts of Kleinpell's Mohnian stage. Several oil fields in the northeastern part of the Los Angeles basin produce from the Soquel member.

The Yorba member consists chiefly of siltstone and is about 275 to 3,000 feet thick. It contains appreciable amounts of interbedded sandstone near the Santa Ana River and in the southern part of the Yorba Linda quadrangle, where some oil is produced from the member. The Yorba member overlies granitic basement rocks in the northeastern part of the map area, but elsewhere it conformably overlies the Soquel mem- 
ber. Foraminiferal faunas from the Yorba member are representative of the Bolivina hughesi zone of the upper part of Kleinpell's Mohnian stage.

The Sycamore Canyon member consists of sandstone, pebbly sandstone, and conglomerate interbedded with varying amounts of siltstone. It is about 175 to 3,600 feet thick and contains foraminiferal faunas representative of the Bolivina hughesi zone of the upper part of Kleinpell's Mohnian stage. In the southeastern part of the Puente Hills, it contains faunas referred to Kleinpell's Delmontian stage of the upper Miocene. Some of the strata included in the member near Prado Dam may be of Pliocene age. Oil is produced from the Sycamore Canyon member along the northeastern margin of the Puente Hills and at oil fields along and south of the southwestern margin of the hills.

The La Vida and Soquel members of the Puente formation are thickest in an area parallel to and 2 or 3 miles northeast of the Whittier fault but they thin rapidly eastward near the Chino fault zone. The Yorba member is thickest in an area parallel to and about 1 mile south of the Whittier fault zone. It also thins rapidly eastward near the Chino fault. The Sycamore Canyon member is thickest in the vicinity of the Chino fault and thins most abruptly to the southwest. Strata of the Soquel, Yorba, and Sycamore Canyon members contain sedimentary features commonly associated with turbidity current deposits.

The Puente formation is overlain by the Fernando formation of Pliocene age. The terms Pico formation and Repetto formation are not applied in this report to rocks of the Puente Hills. The Pliocene rocks there are assigned instead to the Fernando formation, and an upper and a lower member are recognized ; the name Repetto formation is abandoned.

The lower member of the Fernando formation in the eastern Puente Hills consists chiefly of massive or poorly bedded micaceous siltstone containing thin but conspicuous lenses of pebble conglomerate. It is about 700 to 2,600 feet thick and contains some of the oil-producing zones in the Brea-Olinda and other nearby oil fields. The upper member lies unconformably on the lower member in the eastern Puente Hills and consists chiefly of pebbly sandstone and conglomerate. It is the oldest of the units in the mapped area that contain clasts that can be identified as derived from the diabase intrusive bodies along the Whittier fault zone. Beds of varicolored massive sandy siltstone and mudstone occur near the top of the upper member in the western part of the Yorba Linda quadrangle. The upper member is about 900 to 1,400 feet thick. Low gravity oil is produced in the Yorba Linda oil field from coarse-grained rocks in an ancient buried stream channel in the upper member. The Fernando formation contains both molluscan and foraminiferal faunas indicative of a Pliocene age.

The Fernando formation is overlain in the subsurface in the southwestern part of the Yorba Linda quadrangle by an undivided sequence of marine sandstone of early Pleistocene age, and nonmarine mudstone and earthy sandstone beds of Pleistocene age, which has a maximum thickness of about 1,000 feet. The next younger unit is the continental La Habra formation of late Pleistocene age, which consists of mudstone, sandstone, and conglomerate that contains abundant debris derived from the Puente formation. The La Habra formation is 1,000 to 1,500 feet thick and unconformably overlies strata ranging in age from early Pliocene to Pleistocene. Quaternary alluvial terrace deposits of two ages occur near the Santa Ana River; the older is cut by the Whittier fault, and the younger is not.

The Puente Hills area is a structural block that has been uplifted between the Whittier fault zone, which is near the southwestern margin of the hills, and the Chino fault zone, which is near the northeastern margin. The Whittier and Chino faults dip steeply toward each other and converge southeastward, forming a wedge-shaped area occupied by the eastern tip of the Puente Hills. All the pre-upper Quaternary strata exposed between the two faults belong to the Puente formation of late Miocene age. The Fernando formation of Pliocene age is exposed in the map area only south of the Whittier fault zone. The narrow troughlike Chino basin which is northeast of the eastern Puente Hills, is probably the northwestern extension of the Elsinore structural trough. The area northeast of the Chino basin is underlain by a structurally high platform of granitic basement rocks that is covered by a relatively thin veneer of sedimentary rocks. The La Habra syncline, which is south of and nearly parallel to the southern edge of the Puente Hills, lies between the hills and the Coyote Hills uplift to the south.

The Whittier fault trends about N. $70^{\circ} \mathrm{W}$., and along most of its trace in the map area, it is a zone of two or more imbricating faults that dip $70^{\circ}$ to $80^{\circ}$ NE., but near the southeastern end of its trace in the hills, it is a single steep fault. At the western edge of the Yorba Linda quadrangle, the stratigraphic separation across the Whittier fault zone is about 10,500 feet and the upthrown side is on the north. The stratigraphic separation across the fault zone decreases southeastward and is about 2,000 feet near but northwest of the Horseshoe Bend fault. Southeast of the Horseshoe Bend fault the upthrown side of the Whittier fault is on the south. Horizontal movement on the Whittier fault may be no more than about 8,800 feet and is in a right-lateral sense. The Whittier fault may have been active in pre-middle Miocene time, but most of the movement probably occurred during and after the middle Pleistocene regional deformation. Later movement along the fault has tilted and locally overturned beds of the La Habra formation of late Pleistocene age and has cut alluvial terrace deposits at Horseshoe Bend.

The Chino fault is exposed only at the eastern end of the Puente Hills, where it trends about N. $38^{\circ} \mathrm{W}$. and dips $60^{\circ}$ to $65^{\circ}$ southwestward. The stratigraphic separation across the Chino fault near the center of its trace is about 1,200 feet, and the upthrown side is on the southwest. 'The stratigraphic separation across the fault increases southeastward to about 2,400 feet near Prado Dam. Small drag folds northeast of the Chino fault plunge about $72^{\circ}$ southeastward, suggesting a component of lateral displacement in movement on the fault.

The structure of the hills between the Whittier and Chino faults is dominated by northeastward- and eastward-trending faults that branch from, and are probably related to, the Whittier fault zone. Movement on the Arnold Ranch fault is probably responsible for a local unconformity north of the fault where the La Vida member of the Puente formation is absent.

Ten large anticlines are exposed in the hills between the Whittier and Chino faults; oil is produced from two of them. All but the Mahala anticline, which parallels the Chino fault, trend and plunge eastward.

The relief of the Puente Hills is largely the result of uplift of the structural block bounded on the south by the Whittier fault. The course of the Santa Ana River through its canyon between the Puente Hills and Santa Ana Mountains to the 
south is generally considered to antecede the uplift of those areas. Other ancient streams that once crossed the Puente Hills area were diverted around the hills, leaving their beheaded valleys to smaller present-day intermittent streams. The courses of the larger south-trending canyons in the hills are offset as much as 8,800 feet in a right-lateral sense where they cross the Whittier fault zone. These offsets were probably caused by strike-slip movement in a right-lateral sense along the Whittier fault zone in late Pleistocene and Recent time.

Most of the oil produced in the eastern Puente Hills area is obtained from sandstone beds in the Puente formation and in the lower member of the Fernando formation. These units are still the chief objective of exploration in the area. The discovery of the Mahala and Esperanza oil tields suggests that additional oil may yet be found in complex structural features associated with the Chino or Whittier faults.

\section{INTRODUCTION IOCATION OF AREA}

The Puente Hills are in the northeastern part of the Los Angeles basin, in parts of Los Angeles, Orange, San Bernardino, and Riverside Counties, Calif. (figs.
1 and 2). They cover a roughly triangular area bounded on the northwest by the San Gabriel Valley, on the northeast by the San Bernardino Valley, and on the south by the Santa Ana River and the Los Angeles (Downey) Plain. This report is concerned specifically with the eastern part of the Puente Hills and adjacent area lying within the Prado Dam and Yorba Linda 71/2-minute quadrangles.

\section{PURPOSE OF INVESTIGATION}

This study of the geology of the eastern Puente Hills is part of the U.S. Geological Survey's investigation of the Los Angeles basin, one of the most prolific oilproducing regions in California. Nearly all the oil produced in the basin is obtained from strata of late Miocene or Pliocene age. Rocks of this age are concealed in the central part of the basin, but they crop out in structurally elevated areas near the basin edge. The Puente Hills are one such area, and the thick sequence of upper Tertiary and Quaternary strata ex-

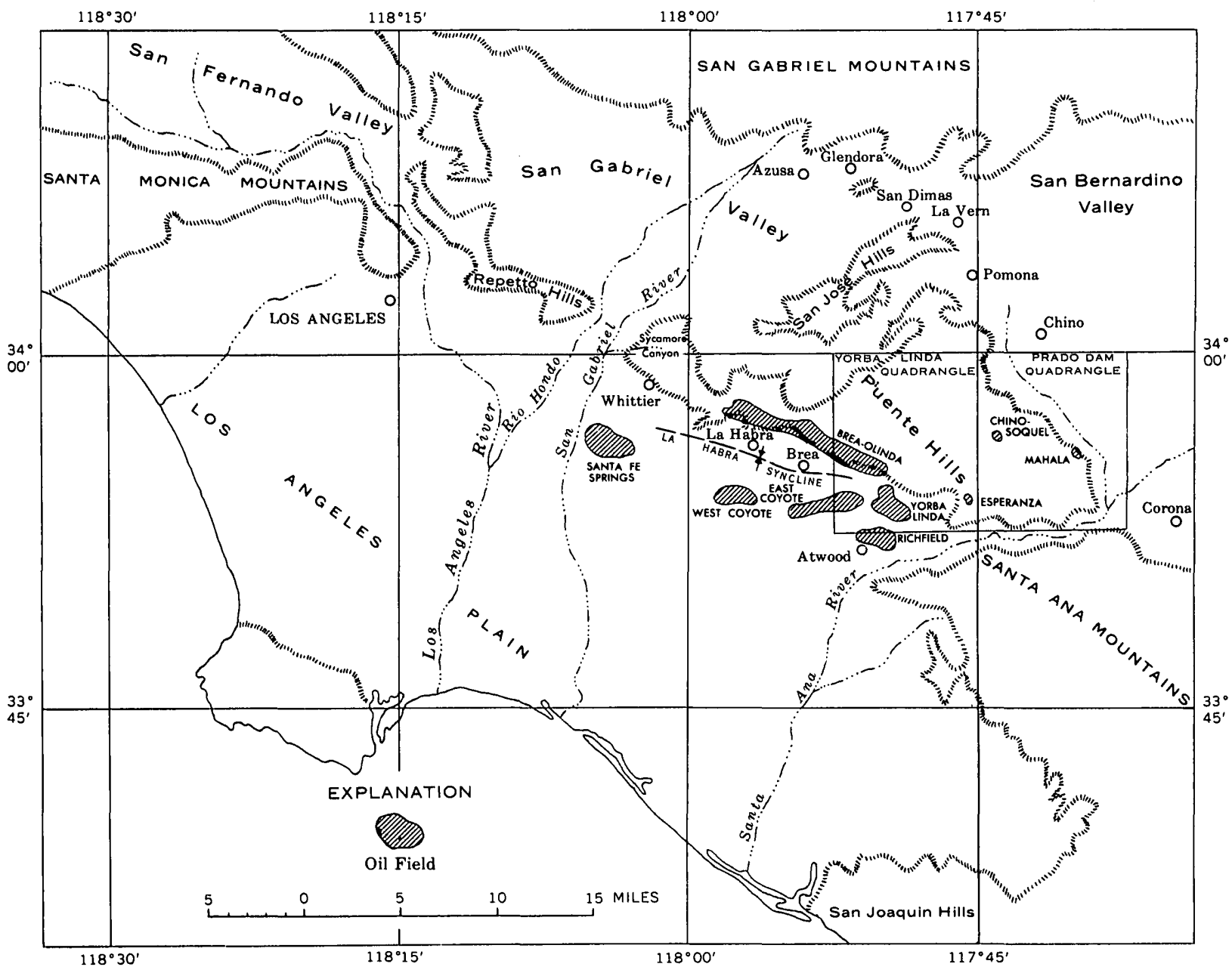

Figurn 1.-Index map showing part of southern California and location of the eastern Puente Huls area. Prado Dam and Yorba Linda quadrangles. 


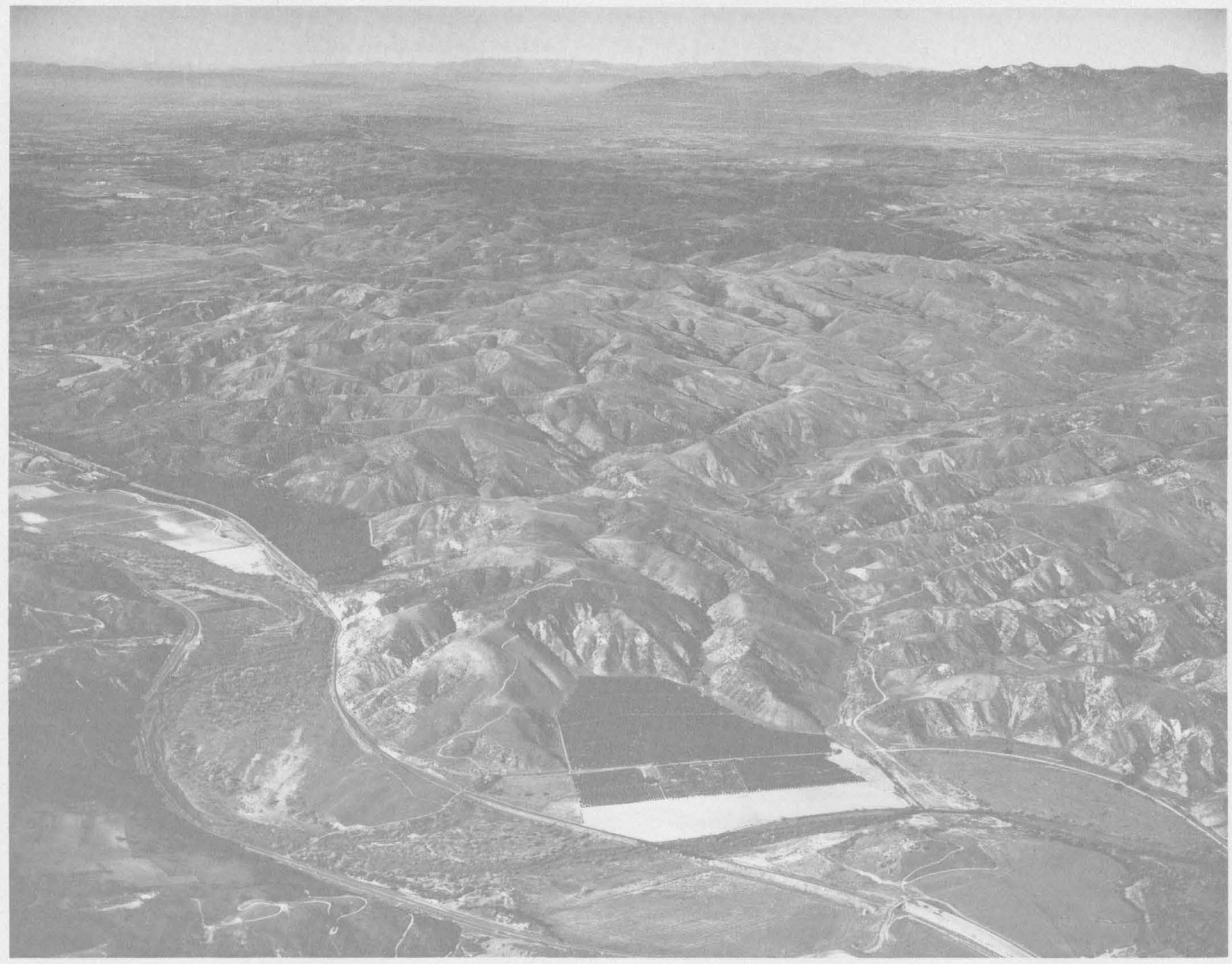

Frgure 2.-Aerial view of the eastern Puente Hills area looking north west from the southeast corner of the map area. Aliso Canyon and the Arena Blanea syneline are in right center; Seully Hill is in lower left center; the Horseshoe Bend of the Santa Ana River is at far left center; the Whittier fault zone trends obliquely across left half of photograph near the margin of the hills; the San Gabriel Mountains are at the skyline on the right.

posed there was mapped in detail as a contribution to the history of sedimentation in the basin. The geologic structure of the eastern Puente Hills - and especially the nature of the Whittier fault-was also studied as essential to an understanding of the structural evolution of the Los Angeles basin. A summary of the known occurrences of oil and gas in the eastern Puente Hills area is included in the section on "Economic geology."

\section{PREVIOUS WORK}

The Puente Hills first attracted the attention of geologists when commercial quantities of oil were discovored there near the end of the 19th century; consequently, the first geologic reports published on the area were concerned chiefly with oil resources, and only incidentally with geology as geologic factors affected the accumulation of oil. A series of publications describing oil resources of the Puente Hills area was begun before 1900 by the California State Mining Bureau and has been continued by the State Division of Oil and Gas. Eldridge and Arnold (1907) described the oil districts of southern California in Geological Survey Bulletin 309. Their report on the Puente Hills included the first systematic study of the stratigraphy of the region and established a foundation for later work. A more detailed account of the geology of the Puente Hills by W. A. English was published in 1926 by the Geological Survey as Bulletin 768. A reconnaissance geologic map of the Puente and San Jose Hills by Woodford, Shelton, and Moran (1944) was 
published by the Geological Survey as Oil and Gas Investigations Preliminary Map 23. This generalized map was accompanied by a number of structure sections and a chart listing available data on exploratory wells.

A preliminary geologic map of the eastern Puente Hills area by Durham and Yerkes (1959) was revised to incorporate information from new excavations and exploratory wells and is included as plate 1 of this report.

\section{FIELDWORK AND PREPARATION OF REPORT}

The Prado Dam quadrangle and that part of the Yorba Linda quadrangle southeast of Carbon Canyon were mapped by Durham between November 1954 and January 1956. The remainder of the Yorba Linda quadrangle was mapped by Yerkes between November 1955 and May 1956. Yerkes followed exploratory drilling and development activities in the area after 1956 and made field checks and map revisions in preparation of this report.

Geologic mapping was done on Geological Survey aerial photographs of a scale of approximately $1: 12$,000 and transferred to the Prado Dam and Yorba Linda 71/2-minute quadrangle maps. While fieldwork was in progress, the Metropolitan Water District of Southern California constructed an aqueduct across the southeastern part of the Puente Hills. Excavations for the pipeline, including a mile-long tunnel, provided a rare opportunity for study of unweathered strata of the Puente formation. Geologic data from the tunnel are presented on pages $\mathrm{B} 57$ to $\mathrm{B} 59$.

\section{ACKNOWLEDGMENTS}

Fieldwork in the eastern Puente Hills was aided by the cooperation of many landowners, to whom the authors are indebted. The authors are also grateful to many oil companies and individual operators for their courtesy in making available records on wells drilled in the area, and to the staffs of the Metropolitan Water District and construction contractors for their cooperation during investigation of the San Juan tunnel and pipeline ditches.

Foraminifera in samples collected from the eastern Puente Hills were identified by Patsy B. Smith, of the U.S. Geological Survey. Mollusks were identified by J. G. Vedder, of the U.S. Geological Survey, who also aided in their collection.

\section{STRATIGRAPHY}

The oldest rocks exposed in the map area are south of the Santa Ana River; they are assigned to the Santiago formation of middle Eocene age. The oldest rocks exposed in the map area north of the Santa Ana River occur near Horseshoe Bend and Scully
Hill; these rocks are correlated with the Vaqueros and Sespe formations undifferentiated, of the Santa Ana Mountains. Most of the rocks exposed northeast of the Whittier fault zone belong to the Puente formation of late Miocene age; most of those exposed south of the fault zone belong to the Fernando formation of Pliocene age, or to younger units. The sedimentary rocks of the eastern Puente Hills area have a composite maximum thickness of more than 27,000 feet (pl. 2).

\section{CRETACEOUS SYSTEM}

\section{PLUTONIC ROCKS}

The sedimentary rocks in the eastern Puente Hills overlie a basement complex consisting chiefly of granodioritic and associated plutonic rocks of the Southern California batholith (Larsen, 1948) with an inferred early Late Cretaceous geologic age and a radiometric age of about 110 million years. (Larsen and others, 1958, p. 48-49.) Near the Chino fault the top of the basement rocks is at an average depth of 4,000 feet below sea level. In the northeastern part of the Prado Dam quadrangle, the basement rock surface is about 1,000 feet below sea level, and $31 / 2$ miles east of the Prado Dam quadrangle basement rocks are exposed. The basement rock surface rises from a depth of 4,378 feet below sea level a mile southwest of Los Serranos in the E. F. Stella well Kraemer-Backs 2 (pl. 1, well 203 ; sec. 33 , T. 2 S., R. 8 W.) to about 2,300 feet below sea level in the Patton well Three Corners 1 (pl. 1, well 126 ; sec. 21 , T. 2 S., R. 8 W.) 2 miles farther north. The exposures of basement rock nearest to the map area are southwest of Pomona at Elephant Hill, 3 miles north of the Yorba Linda quadrangle.

Basement rock found in wells drilled in the eastern Puente Hills area is commonly a rather coarse grained biotite quartz diorite similar to the Bonsall tonalite of Larsen (1948, p. 58-62), but quartz monzonite, granodiorite, and granite also occur.

Basement rocks were found in wells $16,73,102,126$, $132,147,148,149,181,203$, and 252 shown on pl. 1 (see also table 4).

\section{SEDIMENTARY ROCKS}

Sedimentary rocks assigned to the Ladd formation of Late Cretaceous age were found below a depth of 4,500 feet in the Godfrey Drilling Co. well Botiller 1 (pl. 1, well 65; sec. 29, T. 3 S., R. 7 W.), in the southeast corner of the Prado Dam quadrangle at the northern edge of the Santa Ana Mountains. The sequence of Upper Cretaceous strata exposed south of the map area in the Santa Ana Mountains is at least 2,500 feet thick. It overlies the Santiago Peak volcanics of Jurassic(?) age (Larsen, 1948, p. 24) and is overlain by the Silverado formation of Paleocene age. Strata 
of Cretaceous age are absent $71 / 2$ miles northwest of the Grodfrey Drilling Co. well, where granitic basement rocks are overlain by strata of probable Eocene age in the E. F. Stella well Kraemer-Backs 2 (pl. 1, well 203, sec. 33, T. 2 S., R. 8 W.).

\section{TERTIARY SYSTEM}

PALFOCENE SHRTES

SILVERADO FORMATION

Sedimentary rocks of Paleocene age do not crop out and are not known to occur in the subsurface in the eastern Puente Hills area, but they do crop out just south of the Santa Ana River. Strata of Paleocene age in the Santa Ana Mountains were originally assigned by Dickerson (1914) to the Martinez formation of central California; this usage was continued by English (1926, p. 19). Woodring and Popenoe (1945) proposed the name Silverado formation for the distinctive Paleocene strata in the Santa Ana Mountains, and this name has been adopted by other workers in the area.

Steeply dipping strata between depths of 2,685 and 4,500 feet in the Godfrey Drilling Co. well Botiller 1 (pl. 1 well 65 ; sec. 29 , T. 3 S., R. 7 W.) are assigned to the Silverado formation of Paleocene age. In this well the formation consists of about 1,170 feet of interbedded fine-grained silty sandstone, coarse-grained sandstone, and pebbly sandstone. Fine-grained silty sandstone with thin beds of coarser grained sandstone constitute about 25 percent of the formation and occurs in units up to 150 feet thick. Coarse-grained to gritty sandstone containing many red and green sand grains occurs both as thin beds in the fine-grained sandstone and as thicker beds with interbeds of silty sandstone. The Silverado formation overlies strata of Late Cretaceous age in the Godfrey Drilling Co. well.

\section{BOCENE SERIES \\ SANTTAGO FORMATION}

Rocks of Eocene age exposed in the Santa Ana Mountains were correlated with the Tejon formation of central California by Dickerson (1914), and the same assignment was made by English (1926, p. 21). Woodring and Popenoe (1945) proposed the name Santiago formation for rocks of Eocene age that underlie the Sespe formation in the Santa Ana Mountains and tentatively assigned a late Eocene age to them. Schoellhamer and others (1954) adopted the name Santiago formation and assigned a middle Eocene age to it.

Strata assigned to the Santiago formation are exposed at the south edge of the Prado Dam quadrangle, in a small area south of the Santa Ana River where the contact with the overlying Vaqueros and Sespe forma- tions undifferentiated is also exposed. There the Santiago formation has a lower unit about 350 feet thick consisting chiefly of pebble and cobble conglomerate of probable nonmarine origin, and an upper unit about 320 feet thick consisting of sandstone and sandy siltstone. The conglomerate contains well-rounded ,pebbles and cobbles of red and green metavolcanic rocks, lesser numbers of light-colored plutonic and gneissic rocks, and brown quartzite. The pebbles and cobbles are as much as 6 inches long, but average 2 to 3 inches. The red metavolcanic rocks include a distinctive welded tuff containing piedmontite. In the Puente Hills and Santa Ana Mountains, this welded tuff has been found as clasts only in the Santiago formation and the overlying Vaqueros and Sespe formations undifferentiated. Sandstone occurs in the lower conglomeratic unit in beds 1 to 3 feet thick. It is well bedded, laminated, medium to coarse grained, and poorly sorted and contains some carbonaceous material. The sandstone of the upper unit is yellowish gray to light brown, poorly sorted, and massive. The sandy siltstone is yellowish gray, well bedded, and clayey and contains irregular flat limy concretions as much as a foot thick that are oriented parallel to the bedding planes. A few thin beds of clayey siltstone also occur in the Santiago formation.

Eocene strata do not crop out north of the Santa Ana River, but they are probably present in several wells drilled in the map area (pl. 1, wells 65, 77, 107, $108,156,203,206,212)$. Strata penetrated in the E. F. Stella well Kraemer-Backs 2 (pl. 1, well 203; sec. 33, T. 2 S., R. 8 W.) between depths of 4,400 and 5,228 feet that are assigned to the Santiago formation consist of pale-gray moderately well sorted massive very finegrained micaceous silty sandstone containing irregular chips and blobs of dark-gray biotite sandstone. Samples of the rock have a strong odor of clay. Thin beds of coarse-grained sandstone and grit occur with the fine-grained sandstone. The coarse-grained sandstone is light colored, massive, friable, and fairly well sorted. It contains quartz, feldspar, abundant biotite, and rock fragments in a matrix of white clay. The unit contains Foraminifera considered to be no younger than late Eocene in age (Woodford and others, 1944) and overlies granitic basement rock.

Strata tentatively assigned to the Santiago formation were penetrated in the Tidewater Oil Co. well Abacherli 1 (pl. 1, well 212; sec. 12, T. 3 S., R. 8 W.) between depths of about 4,200 to 4,800 feet. The unit consists chiefly of dark-olive-green sandy siltstone and fine-grained silty sandstone. It contains abundant biotite and some feldspar. Laminae and thin beds of light-greenish-gray medium-grained sandstone are interbedded in the fine-grained rock. The sandstone is 
micaceous and ripplemarked. Cores from 4,500 to 4,717 feet depth in the Tidewater Oil Co. well contain Foraminifera similar to those in strata of Late Cretaceous to Eocene age. Cores from 4,960 feet to the bottom of the well at 4,977 feet consist of conglomerate containing pebbles and cobbles of red and green metavolcanic rocks. The bottom sample includes a 3-inch pebble of distinctive red welded tuff containing piedmontite.

\section{UPPER EOCENE TO LOWER MIOCENE SERIES}

\section{VAQUEROS AND SESPE FORMATIONS UNDIFFERENTIATED}

The oldest rocks exposed in the eastern Puente Hills are correlated with the Vaqueros and Sespe formations undifferentiated, of the Santa Ana Mountains. The Sespe formation was first described by Watts (1897) and was later defined by Eldridge and Arnold (1907) and by Kew (1924). The type locality of the Sespe formation is at Sespe Creek, which enters the Santa Clara River in Ventura County 15 miles west of the Ventura-Los Angeles County line. At the type locality the Sespe formation consists chiefly of reddishbrown sandstone and conglomerate interbedded with siltstone. Vertebrate faunas collected from the Sespe formation outside of the Puente Hills indicate that it is of continental origin and ranges from late Eocene to early Miocene in age (Bailey and Jahns, 1954).

The oldest marine Miocene rocks in southern California contain the Turritella inezana fauna and are generally assigned to the Vaqueros formation. This formation was named and described by Hamlin (1904), who gave as its type locality the area along Vaqueros Creek in the Santa Lucia Range in west-central California. Although Kew (1924) and other workers distinguished the Vaqueros formation from the Sespe formation in areas north of the Los Angeles basin, the two formations have generally been mapped as a unit in the Santa Ana Mountains (English, 1926; Schoellhamer and others, 1954). In the eastern Puente Hills, strata containing marine fossils are interbedded with the Sespe formation, but the marine strata cannot be mapped as a separate unit excluding red beds typical of the Sespe formation.

\section{Distribution and character}

Two isolated exposures of red beds in the eastern Puente Hills - one at Scully Hill and the other northeast of Horseshoe Bend-are correlated on the basis of lithology and stratigraphic position with the Vaqueros Sespe formations undifferentiated of the Santa Ana Mountains. Similar strata were found in several wells drilled in the map area (pl. 1, wells 65 , $73,77,107,108,126,132,156,181,203,206,212,219$, $250)$. These beds are generally recognized in the subsurface by their stratigraphic position, lithologic character, and reddish-brown color.

The red beds at Scully Hill, where they are well exposed in railroad cuts near the Santa Ana River, consist of medium- to coarse-grained light-reddishbrown feldspathic sandstone that is cross-stratified in places. Strata in a fault-bounded area just south of the Whittier fault near Horseshoe Bend are also correlated with the Vaqueros and Sespe formations. They consist of medium- to coarse-grained reddish-brown sandstone interbedded with brown poorly sorted coarse-grained to conglomeratic sandstone and darkgray carbonaceous siltstone containing poorly preserved marine megafossils.

Strata of the Vaqueros and Sespe formations undifferentiated, exposed in roadeuts immediately south of the Santa Ana River, consist of reddish-brown cobble and boulder conglomerate with a matrix and some beds of poorly cemented reddish-brown and greenishgray feldspathic sandstone (fig. 3). About 20 percent of the cobbles and boulders are composed of resistant dark-red or purplish-red volcanic rock. Farther east, near the southeast corner of the Prado Dam quadrangle, the unit is generally finer grained and consists mainly of poorly bedded reddish-brown and greenish-gray massive sandstone and sandy siltstone, with lesser amounts of conglomerate and conglomeratic sandstone.

\section{Thickness}

The red beds exposed at Scully Hill that are assigned to the Vaqueros and Sespe formations undifferentiated are about 50 feet thick, but these beds represent only the upper part of the unit. Strata assigned

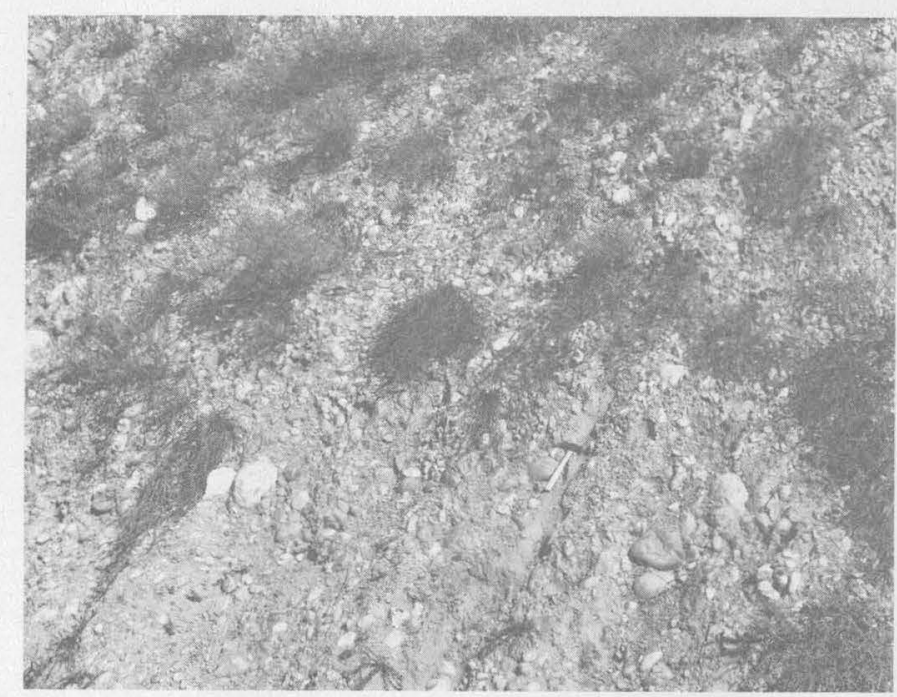

Figure 3.-Typical exposure of sandstone and conglomerate of the Vaqueros and Sespe formations undifferentiated, in roadeut south of the Santa Ana River in the Prado Dam quadrangle. The bedding is parallel to the hammer handle. 
to the Vaqueros and Sespe formations in the subsurface of the eastern Puente Hills are as much as 700 feet thick. In the subsurface at the Richfield oil field, nonmarine red beds correlated with the Sespe formation are at least 1,200 feet thick (Wissler, 1943, p. 225), and marine(?) beds equivalent in age to the Vaqueros formation are about 150 feet thick.

\section{Age and stratigraphic relations}

The only fossils found in the Vaqueros and Sespe formations in the eastern Puente Hills are poorly preserved unidentifiable marine mollusks from a locality near Horseshoe Bend. The base of the unit is not exposed in the eastern Puente Hills, but in the subsurface the formation overlies the Santiago formation of middle Eocene age and plutonic basement rocks. At Scully Hill the Vaqueros and Sespe formations undifferentiated are overlain with apparent conformity by the Topanga formation of middle Miocene age. The top of the unit is not exposed elsewhere in the eastern Puente Hills.

\section{MIDDLE MIOCENE SERIES} TOPANGA FORMATION

The Topanga formation was first defined by Kew (1924, p. 417) and named for its exposures in Topanga Canyon in the Santa Monica Mountains. These beds had previously been considered as part of the Vaqueros formation, but Kew restricted use of the term Vaqueros to rocks containing the Turritella inezana fauna of early Miocene age, and included rocks containing the middle Miocene Turritella ocoyana fauna in his new Topanga formation. The name was later adopted by English (1926) for similar rocks exposed in the Santa Ana Mountains and on the southern edge of the eastern Puente Hills.

\section{Distribution and character}

The Topanga formation is exposed at two places in the eastern Puente Hills: north and east of Horseshoe Bend on the Santa Ana River and at Scully Hill (fig. 4). At Horseshoe Bend the Topanga formation consists chiefly of light-yellowish brown and nearly white medium- to fine-grained feldspathic sandstone containing lenses of conglomerate and sandy conglomerate. Appreciable amounts of sandy siltstone are also present locally in the unit. Most of the sandstone is thick bedded to massive, but locally it is thin bedded and contains interbedded siltstone. Much of the sandstone is poorly sorted, and stringers or thin lenses of pebble and cobble conglomerate are common. The sandstone has an abundant matrix of fine silt or clay. Poorly preserved marine mollusks of middle Miocene age have been found at several localities, particularly where fine-grained sandstone and sandy siltstone are present in the formation. Strata of the Topanga formation exposed at Scully Hill (fig. 5) are similar to those at Horseshoe Bend.

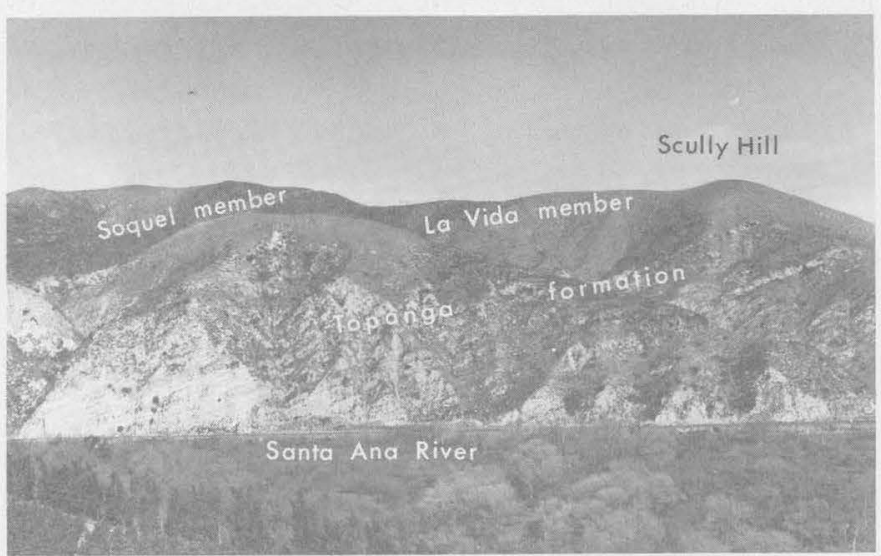

Figure 4.- Pebbly sandstone and conglomerate beds of the Topanga formation are exposed in the bold outcrops near the base of Scully Hill. The smooth slopes above are underlain by siltstone beds of the La Vida member of the Puente formation. The brush-covered slopes along the skyline at the left are underlain by sandstone beds of the Soquel member of the Puente formation. View northward across the Santa Ana River toward Scully Hill.

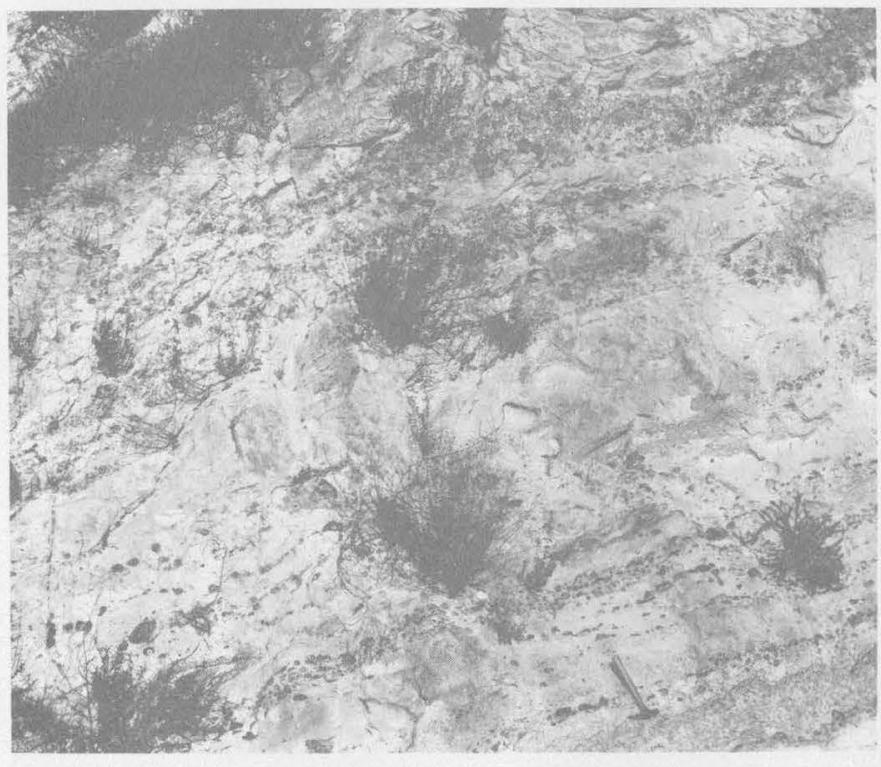

Figure 5.-Pebbly sandstone of the Topanga formation exposed in a railroad cut near the western end of Scully Hill.

The Topanga formation is present in the subsurface over most of the eastern Puente Hills area (table 4). Core samples from the formation generally consist of either white to gray well-indurated massive fine- to coarse-grained and pebbly sandstone, or hard darkgray to black siltstone that commonly contains fish scales of middle Miocene age (Woodford and others, 1944). 
A core from the Topanga formation between 5,859 and 5,865 feet in the Shell Oil Co. well Keeler Community 1 (pl. 1 , well 167 ; sec. 6, T. 3 S., R. 9 W.) consists of poorly sorted massive dense dark-gray sandstone. In a thin section of the sandstone, the grains are sharply angular to subrounded and range from 0.02 to 2.7 millimeters in size, averaging 0.1 millimeter. The rock consists of about 38 percent andesine, 37 percent quartz, 2 percent orthoclase, 1 percent biotite and muscovite, 4 percent rock fragments (quartzite, volcanic rocks, granitic rock, and shale), 18 percent rock flour composed of quartz and clayey and micaceous material, and less than 1 percent epidote, titanite, and tourmaline.

Thiokness

The Topanga formation is at least 800 feet thick at Scully Hill. The formation is probably thicker at Horseshoe Bend, but its true thickness there is obscure because of structural complications.

The Topanga formation was found in at least 31 wells drilled in the eastern Puente Hills area (pl. 1, wells $12,41,70,73,74,77,88,89,105,107,108,118,126$, $132,150,155,156,167,181,184,203,208,210,212$,213, $214,219,221,231,240,250)$. The formation is about 2,100 feet thick. in the Western Gulf Oil Co. well Diamond Bar 1 (pl. 1, well 250; sec. 28, T. 2 S., R. 9 W.), but it is only 1,038 feet thick in the Douglas Marcell well Puente Hills 1 (pl. 1, well 108; sec. 31, T. 2 S., R. 8., W.), less than 5 miles east, and only 220 feet thick in the Tidewater Oil Co. well Abacherli 1 (pl. 1, well 212 ; sec. 12, T. 3 S., R. 8 W.), located at the eastern end of the Puente Hills (pls. 3, 4). The Topanga formation is about 975 feet thick (pl. 3) in the subsurface at the Richfield oil field (Wissler, 1943, p. 224).

Fossils

Marine fossils are scarce in the Topanga formation in the eastern Puente Hills and most are fragmentary or poorly preserved. The faunas listed below were collected from three localities east of Horseshoe Bend (sec. 28, T. 3 S., R. 8 W.) and were identified by J. G. Vedder, of the U.S. Geological Survey. The genera of gastropods and pelecypods are listed alphabetically.

Locality F-1 :

Gastropods :

Amphissa? sp.

Cerithium topangensis Arnold Potamides? sp.

Pelecypods :

Aequipecten cf. A. andersoni (Arnold)

Clementia pertenuis (Gabb)

Dosinia cf. D. matluewsonii Gabb

Miltha sanctaecrucis (Arnold)

Panope ef. gencrosa (Gould)

Pinna? sp.

Spisula?sp.
Locality F-2 :

Gastropods :

Turritella cf. T. ocoyana Conrad

Pelecypods :

Clementia pertenuis (Gabb)

Locality F-3 :

Gastropods :

Scaphander cf. S. jugularis (Conrad)

Tegula cf. T. thea Nomland

Turritella ocoyana Conrad?

Pelecypods :

Lyropecten cf. L. crassicardo (Conrad)

Age and stratigraphic relations

The Topanga formation of the eastern Puente Hills overlies the Vaqueros and Sespe formations undifferentiated; of late Focene -to early Miocene age it is overlain in turn either by volcanic rocks or by the Puente formation of late Miocene age. Fossils collected from the Topanga formation near Horseshoe Bend are of middle Miocene age. J. G. Vedder (written communication, 1958) made the following statement concerning these collections:

Most of the forms listed occur in both the early and middle Miocene of southern California, but the complete lack of early Miocene guide forms and the fact that most of the species listed rarely are present in early Miocene strata indicate that the age of the fauna is middle Miocene. Tegula thea previously has been reported only from late Miocene strata (Santa Margarita formation) northeast of Coalinga.

The apparently conformable contact between the Topanga formation and the underlying red beds of the Vaqueros and Sespe formations undifferentiated is exposed at Scully Hill. The Topanga formation is unconformably overlain by the La Vida member of the Puente formation in the same area (fig. $4 ; \mathrm{pl} .4$ ).

\section{Conditions of deposition}

The Topanga formation contains marine fossils at many localities and is of marine origin in most areas of the Los Angeles basin. Faunas from the formation commonly consist of shallow-water forms (Woodford and others, 1954, p. 69), and in the northeastern part of the Los Angeles basin the Topanga formation is generally less fossiliferous than elsewhere. Fine-grained rocks of the Topanga formation penetrated by wells drilled in the eastern Puente Hills commonly contain fish scales and Foraminifera. Marine mollusks are present in the Topanga formation east of Horseshoe Bend.

Woodford and others (1946, fig. 10, p. 557) suggest that the shoreline in middle Miocene time probably extended eastward north of Azusa and Glendora to the area just east of San Dimas, turned southeastward toward the San Jose Hills, and continued southeastward near the margin of the eastern Puente Hills toward the Santa Ana River. With this location of the shoreline the Topanga formation of the eastern 
Puente Hills area would be entirely of marine origin and probably of a near-shore facies.

DIAMOND BAR SAND

\section{Distribution and character}

The Diamond Bar sand is an informal name used by Woodford and others (1944) for a subsurface unit here included in the Topanga formation. It has not been recognized outside the Yorba Linda quadrangle. Woodford and others (1944) assigned it to the lower part of the Puente formation and named it for its occurrence in the Western Gulf Oil Co. well Diamond Bar 1 (pl. 1, well 250, sec. 28, T. 2 S., R. 9 W. ) where it underlies strata of the La Vida member of the Puente formation. It is found in at least 11 wells (pl. 1, wells $2,40,67,134,139,157,167,170,172,221,250)$. The northern limit of the sand coincides approximately with the northern edge of the Yorba Linda quadrangle; the eastern limit is near Carbon Canyon in the northern part of the Yorba Linda quadrangle; its extent to the south and west is not known. The Diamond Bar sand occupies a stratigraphic position similar to that of the Buzzard Peak conglomerate member of the Topanga formation in the San Jose Hills (Woodford and others, 1946, p. 515, 518; Shelton, 1955, p. 76), and it is here correlated with the Buzzard Peak conglomerate member. Cores recovered from the Diamond Bar sand consist of unusually dense well-cemented sandstone, pebbly sandstone, and conglomerate.

A core of the Diamond Bar sand from 4,798 to 4,808 feet depth in the Shell Oil Co. well Keeler Community 1 (pl. 1, well 167; sec. 6, T. 3 S., R. 9 W.) consists of dense medium-gray poorly sorted massive to crudely bedded sandstone. In a thin section the sand grains are subangular and range from 0.1 to $3.0 \mathrm{~mm}$ in size, averaging $0.25 \mathrm{~mm}$ in long dimension. The rock consists of about 43 percent andesine, 24 percent quartz, 2 percent pyrite, less than 1 percent biotite, muscovite, and chlorite, 12 percent rock fragments composed of volcanic and granitic rock, quartzite, and shale, and 19 percent rock flour composed of quartz, micaceous and clayey material, and chlorite.

\section{Thickness}

The Diamond Bar sand is about 1,650 feet thick in the Western Gulf Oil Co. well Diamond Bar 1 (pl. 3). The sand thins to about 160 feet in the Albercalif Petroleums, Ltd., well Stoody 30-4 (pl. 1, well 2; sec. 30, T. 2 S., R. 8 W.), probably because its upper part was removed by erosion at the unconformity at the base of the overlying Puente formation. In the Union Oil Co. well Gaines 1 (pl. 1, well 221; sec. 10, T. 3 S., R. 9 W.), the Diamond Bar sand may be as much as 2,500 feet thick (pl. 3). Along the Whittier fault zone in the west-central part of the Yorba Linda quadrangle it is as much as 1,300 feet thick (pl. 3).

\section{Age and stratigraphic relations}

The Diamond Bar sand overlies volcanic rocks of Luisian (late middle Miocene) age in wells just north of the Whittier fault zone, and is overlain by the $\mathrm{La}$ Vida member of the Puente formation of Mohnian (early late Miocene) age. In the Western Gulf Oil Co. well Diamond Bar 1, the Diamond Bar sand overlies strata of the Topanga formation consisting chiefly of shale, but in several other wells it overlies volcanic rocks of middle Miocene age, which in turn overlie sandstone of the Topanga formation. In wells in which the volcanic rocks are absent, or were not reached, the unit is recognized by its coarse, hard, and dense character.

\section{Conditions of deposition}

Siltstone partings in the Diamond Bar sand contain fish scales probably indicating deposition in a marine environment. Its basin of deposition occupied the central part of the Yorba Linda quadrangle and its northern and eastern margins coincided approximately with the northern and eastern edges of the Yorba Linda quadrangle. Volcanic debris in the sand was probably derived from underlying volcanic rocks by erosion at the margins of the basin.

\section{VOLCANIC ROCKS ASSOCIATED WITH THE TOPANGA} FORMATION

\section{Distribution and stratigraphic relations}

Volcanic rocks are not exposed in the eastern Puente Hills, but they do occur in the subsurface in the Yorba Linda quadrangle. Although volcanic rocks were found in eight wells drilled in the map area (pl. 1, wells $2,73,126,132,167,181,219,221$ ), they were not found in a number of other wells drilled through the horizon at which the volcanics occur. The sporadic occurrence of the volcanic rocks is probably the result both of their original distribution being controlled by topography and of their removal by erosion from parts of the area.

Volcanic rocks were found just north of the Whittier fault zone in the Shell Oil Co. well Keeler Community 1 (pl. 1 , well 167 ; sec. 6 , T. 3 S., R. 9 W.) and in the Union Oil Co. well Gaines 1 (pl. 1, well 221; sec. 10, T. 3 S., R. 9 W.) (pl. 3). They are fine-grained basaltic rocks (olivine-bearing, amygdular, and glassy in the Union well Gaines 1), which are interpreted as remnants of flows. A core sample of basaltic rock from 6,020 feet depth in the Union Oil Co. well Gaines 1 is identical with a sample from 7,915 feet depth in the Union Oil Co. well Chapman 29 (pl. 1, well 219; sec. 29 , T. 3 S., R. 9 W.), located south of the Whittier 
fault zone on the northern flank of the Richfield oil field (pl. 1). The volcanic rocks in these three wells are correlated with the El Modeno volcanics of the Santa Ana Mountains (Yerkes, 1957).

The Albercalif Petroleums, Ltd., well Stoody 30-4 (pl. 1, well 2; sec. 30 T. 2 S., R. 8 W.), in the northern part of the Yorba Linda quadrangle, penetrated the La Vida member of the Puente formation, about 160 feet of the Diamond Bar sand and about 200 feet of volcanic rocks without reaching their base (fig. 18). The Shell Oil Co. well Puente Core Hole 4 (pl. 1, well 181 ; sec. 18, T. 2 S., R. 8 W.), drilled about 2 miles farther north, penetrated about 120 feet of glassy porphyritic basalt and massive olivine basalt overlying beds of the Topanga formation of middle Miocene age and unconformably overlain by strata of the Soquel member of the Puente formation. In this well the La Vida member of the Puente formation and probably part of the volcanic sequence are absent beneath an unconformity at the base of the Puente formation. A similar stratigraphic section, including the unconformity, was penetrated by the Patton Oil Co. well Three Corners 1 (pl. 1, well 126; sec. 21 , T. 2 S., R. 8 W.), near the northwest corner of the Prado Dam quadrangle. North of the Yorba Linda quadrangle the unconformity truncates successively older strata; at Elephant Hill, just southwest of Pomona, the Soquel member of the Puente formation lies directly upon plutonic basement rocks. Volcanic rocks lying on granitic basement rocks were found in two wells drilled between Elephant Hill and the Yorba Linda quadrangle.

\section{Petrography}

The color of the volcanic rocks ranges from light or dark gray to greenish gray. Their texture ranges from fine-grained hyalopilitic to vitrophyric and porphyritic, and some samples are coarsely amygdaloidal. They are apparently basalt or basaltic andesite in composition. Calcic andesine commonly occurs in the rock as acicular laths and tablets having albite or carlsbad twinning and is usually moderately to severely altered. Augite, which occurs as crystals in the glassy phases, is rarely unaltered and is ordinarily recognized only by the crystal outlines of its chlorophaeite pseudomorphs. Chlorophaeite, produced by alteration of augite and glass, is present as conspicuous amygdules in samples from the Shell Oil Co. well Puente Core Hole 4 and from the Union Oil Co. well Chapman 29. Olivine also occurs in the samples from these wells. Clear glass with an index of refraction of $1.555 \pm .002$ is present in samples from the Union Oil (o. wells Gaines 1 and Chapman 29. Magnetite(?) is commonly present in the rock as well-disseminated small grains and plates, and calcite is common as vein and cavity fillings.

\section{Age and correlation}

The volcanic rocks found in several wells along and just north of the Whittier fault zone are probably of the Luisian stage (late middle Miocene). They occupy the same stratigraphic position as do the El Modeno volcanics of the Santa Ana Mountains and are correlated with them. The volcanic rocks found in wells drilled in the northern part of the Yorba Linda quadrangle are tentatively correlated with the. Glendora volcanics of the San Jose Hills. The main body of the Glendora volcanics in the San Jose Hills lies within and below the Topanga formation of middle Miocene age (Shelton, 1955). The exposure of Glendora volcanics nearest to the map area are those at Elephant Hill, where rhyolitic rocks overlie granitic basement rocks and are unconformably overlain by the Soquel member of the Puente formation. Volcanic rocks occur in a similar stratigraphic position in several wells drilled between Elephant Hill and the Yorba Linda quadrangle, suggesting that a sheet of volcanic rock may once have extended from Elephant Hill into the Yorba Linda quadrangle. If this were true, then use of the name "Glendora volcanics" in the eastern Puente Hills might be justified; however, the volcanic rocks at Elephant Hill are rhyolitic in composition, and those in the Yorba Linda quadrangle are commonly basalt or basaltic andesite.

\section{UPPER MIOCENE SHRIES}

PUENTE FORMATION

Upper Miocene rocks exposed around the northeastern and eastern margins of the Los Angeles basin are assigned to the Puente formation. This unit, which consists almost entirely of clastic rocks-siltstone, sandstone, and conglomerate-may be divided in most areas into members of characteristic lithologic makeup and stratigraphic position. The formation is more uniform toward the central part of the Los Angeles basin, where it is not divisible on lithologic character. Even where the formation is exposed in the Puente Hills, the orderly succession of members is obscured in some places by the absence of distinctive rock types. The members commonly have gradational upper and lower contacts, and in the Ridge syncline area they may intertongue with one another as a result of lateral changes in lithologic character.

The Puente formation was named by Eldridge and Arnold (1907, p. 103) for its exposures in the Puente Hills. They recognized a lower shale member, an intermediate sandstone member, and an upper shale member. Later, English (1926) mapped the formation in the Puente Hills and on Burruel Ridge, south 
of the Santa Ana River. He also divided it into a lower shale, a middle sandstone, and an upper member that included a varied sequence of siltstone, sandstone, and conglomerate beds. Daviess and Woodford (1949) separated the Puente formation at the western end of the Puente Hills into four members: a lower siltstone member, a sandstone member, an upper siltstone member (these members corresponding generally to the threefold division of previous workers), and the Sycamore Canyon member at the top. In the western Puente Hills the Sycamore Canyon member consists mainly of strata that were included with the overlying Pliocene sequence before their late Miocene age was noted by Krueger (1936). Schoellhamer and others (1954) recognized four members of the Puente formation in the Santa Ana Mountains and gave the names La Vida, Soquel, and Yorba members to the units corresponding to the lower siltstone, middle sandstone, and upper member, respectively, of previous workers. They adopted Daviess and Woodford's (1949) use of the term Sycamore Canyon for the fourth, uppermost member. The Puente formation is considered to be a local equivalent of the upper Miocene part of the more widespread Monterey shale; it is equivalent in age but distinctly different in lithology and depositional environment.

Foraminifera belonging to both the Mohnian and the Delmontian(?) stages of Kleinpell (1938) occur in the Puente formation (table 1). The youngest beds, mapped as part of the Sycamore Canyon member near Prado Dam and to the north along the Ridge syncline, may be of early Pliocene age. Foraminifera are generally scarce in the formation, probably because of their destruction by weathering. This paucity of Foraminifera, as well as the peculiarity of some faunas, might also be the result of unfavorable living conditions for marine organisms in the area at the time the Puente formation was deposited. Foraminifera are abundant locally in fresh rock from well cores, and in some areas subdivision of the formation in the subsurface is based solely on faunal differences. Most of the Foraminifera are consiclered to be deepwater forms.

The Puente formation has a composite maximum thickness of about 13,000 feet in the eastern Puente Hills. It is considerably thinner to the south in the Santa Ana Mountains and to the north in the San Jose Hills.

\section{Distribution and character}

$$
\text { LA VIDA MEMBER }
$$

The La Vida member of the Puente formation was named by Schoellhamer and others (1954) for exposures near La Vida Mineral Springs in the Carbon
Canyon area of the eastern Puente Hills. The principal outcrop areas of the member in the eastern Puente Hills are in Brea, Carbon, and Telegraph Canyons, and at Scully Hill. It is composed almost entirely of interbedded clastic rocks of three types: soft gray micaceous siltstone; hard platy locally laminated calcareous siltstone; and gray commonly silty mediumgrained feldspathic sandstone. In outcrops typical of the La Vida member, less than one-third of the rock consists of sandstone and the sandstone that is present is generally in thin isolated beds. The rock most characteristic of the member is hard platy calcareous and siliceous siltstone like that illustrated in figure 6 . The siltstone is usually light brown, light pinkish brown, or light gray to almost white. It is thin bedded and commonly laminated. In surface exposures it occurs as angular platy fragments measuring several inches on a side and as much as half an inch in thickness. The platy siltstone contains hard limy concretions occurring individually and as concretionary lenses or beds (fig. 6). These concretions are light gray inside, but their weathered surfaces are either almost white or rusty yellowish brown. The largest are several feet in longest dimension. The soft siltand weathers to light brown or pinkish brown. The siltstone is conspicuously micaceous and is commonly speckled on bedding surfaces with small white or rusty-brown spots of unknown origin. Units within the member that have a high percentage of sandstone commonly grade both vertically and laterally into siltstone units that are softer and more massive bedded. Sandstone in the La Vida member is feldspathic and generally micaceous. The sandstone beds range in thickness from a fraction of an inch to several feet, but beds from 1 to 6 inches thick are most common. The sandstone is light gray to gray and weathers to yellow brown or brown Some of the sandstone beds are graded or cross-stratified.

A core of the La Vida member from 2,853 to 2,860 feet depth in the Shell Oil Co. well Keeler Community 1 (pl. 1, well 167; sec. 6, T. 3 S., R. 9 W.) consists of medium-gray poorly sorted massive loosely packed fine-grained sandstone. In a thin section of this sandstone, the grains are angular to subangular, and range in size from 0.04 to 0.8 millimeters, averaging 0.14 millimeters in long dimension. The rock consists of about 30 percent quartz, 25 percent andesine, 4 percent biotite, 1 percent orthoclase (doubtful), less than 1 percent muscovite, 7 percent rock fragments (quartzite, volcanic rock, marble, and granitic rock), 1 percent opaque ores and chlorite, and 32 percent calcite cement and rock flour that includes mica, quartz, and chlorite. 


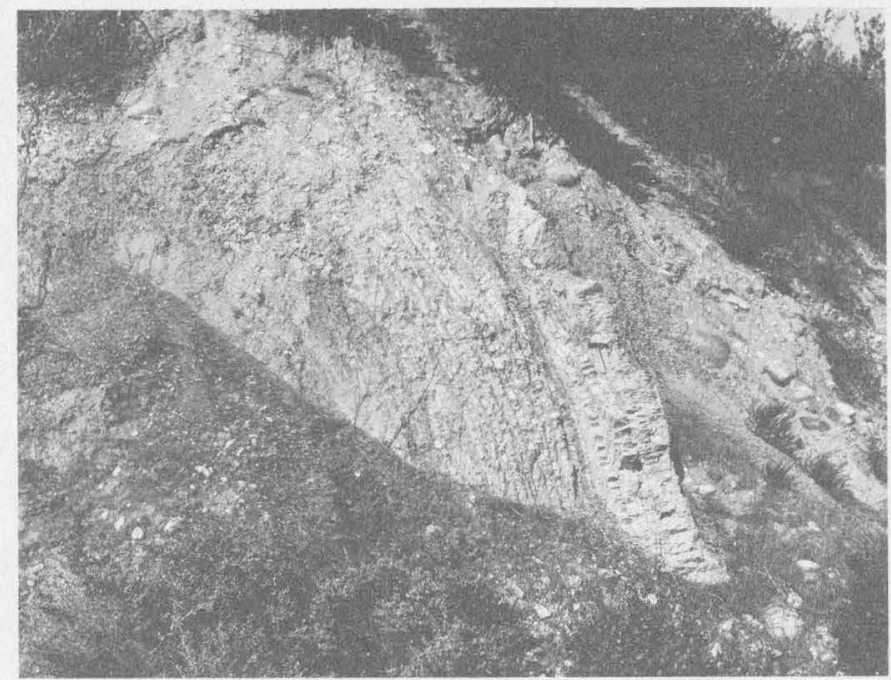

Figure 6.-Platy siltstone of the La Vida member of the Puente formation exposed in a roadeut near the center of section $27, T$. 3 S., R. 8 W. The hammer rests on a lighter colored hard calcareous concretionary bed typical of parts of the member. The boulders and cobbles at the right are debris from terrace deposits above.

The thin-bedded strata of the La Vida member are severely contorted and crumpled in many places, demonstrating their inherent weakness as contrasted with sandstone of the Soquel member. Creeping and sliding of surficial material on hillsides underlain by siltstone of the La Vida are common. Good exposures of the member are found only along streams and in artificial excavations.

A bed 10 to 15 feet thick of basaltic crystal tuff occurs about 1,900 feet stratigraphically below the top of the La Vida member just west of Brea Canyon. The tuff is pale brown, powdery, and intensely weathered. It is associated with beds of limy siltstone 1 to 2 feet thick. The tuff bed is exposed and can be traced west of Brea Canyon for 3.5 miles, but it is not exposed east of the canyon. The tuff bed has been identified from cores, cuttings, or its distinctive appearance on electric logs in 11 wells (pl. 1, wells $47,48,64,76,108,134$, $137,139,167,221,250)$. In well samples the tuff is white, compact, homogeneous, and fine grained. It exhibits some of the characteristics of, and is often described as, bentonite, even though it contains numerous plagioclase crystals.

With the exception of the Ginter and Associates well Kraemer-Backs 3, which is in the Prado Dam quadrangle, all the wells in which the tuff is identified are north of the Whittier fault zone in the Yorba Linda quadrangle. The eastern limit of the tuff beds, like that of the middle Miocene volcanic rocks, is apparently near the eastern edge of the Yorba Linda quadrangle. The absence of the tuff in most of the Prado
Dam quadrangle may be due to nondeposition there rather than to removal by erosion. The part of the stratigraphic section in which the tuff bed occurs is rarely penetrated by wells drilled south of the Whittier fault zone. West of the Yorba Linda quadrangle similar tuff beds are locally present lower in the La Vida member.

\section{Thickness}

The La Vida member is thickest in an area parallel to and about 2 miles northeast of the Whittier fault zone. Near the western edge of the Yorba Linda quadrangle, the exposed thickness of the member is about 3,300 feet, and an additional 500 feet of strata are concealed (pl. 3). It is about 700 feet thick in the southern part of the Prado Dam quadrangle. The La Vida member thins rapidly northeast toward the Arnold Ranch fault, north of which it is commonly absent below an unconformity at the base of the next younger Soquel member. The La Vida member is about 975 feet thick in the Richfield oil field (pl. 3) and about 515 feet thick near the southeast corner of the Yorba Linda quadrangle (pl. 4).

\section{Fossils}

Foraminifera are relatively scarce in both outcrop and well samples of the La Vida member from the eastern Puente Hills. Faunas from the member are listed on the checklist of Foraminifera (table 1). Samples from the La Vida member at localities $\mathrm{f}-6$ and f-8 were collected and studied by M. N. Bramlette, (written communication) who assigned the faunas from them to the Bulimina uvigerinaformis zone of Kleinpell's Mohnian stage.

\section{Age and stratigraphic relations}

Faunas characteristic of the Butimina uvigerinaformis zone of the lower part of Kleinpell's Mohnian stage of upper Miocene age are present in the upper part of the La Vida member in the Puente Hills, but the lower part has not yielded Foraminifera in this area (Woodford and others, 1946, p. 520). The La Vida member is much thinner in the San Jose Hills to the north, but there it has yielded in addition to the Bulimina uvigerinaformis faunas, the older, lowest Mohnian Bolivina modeloensis (or Baggina californica) fauna from beds just above the Buzzard Peak conglomerate member of the Topanga formation (Woodford and others, 1944).

The only exposure of the base of the La Vida member in the Puente Hills is at Scully Hill. There the member overlies the Topanga formation with an angular discordance of $30^{\circ}$. The contact of the La Vida member with the overlying Soquel member is well exposed in Carbon Canyon, where the two members are conformable and gradational. 
TABLE 1.-Stratigraphic distribution of Foraminifera from the [Identiflcations by Patsy B. Smith, U.S. Geol. Survey. Symbols indicating abundance of species in samples containing a large fauna: A, abundant;

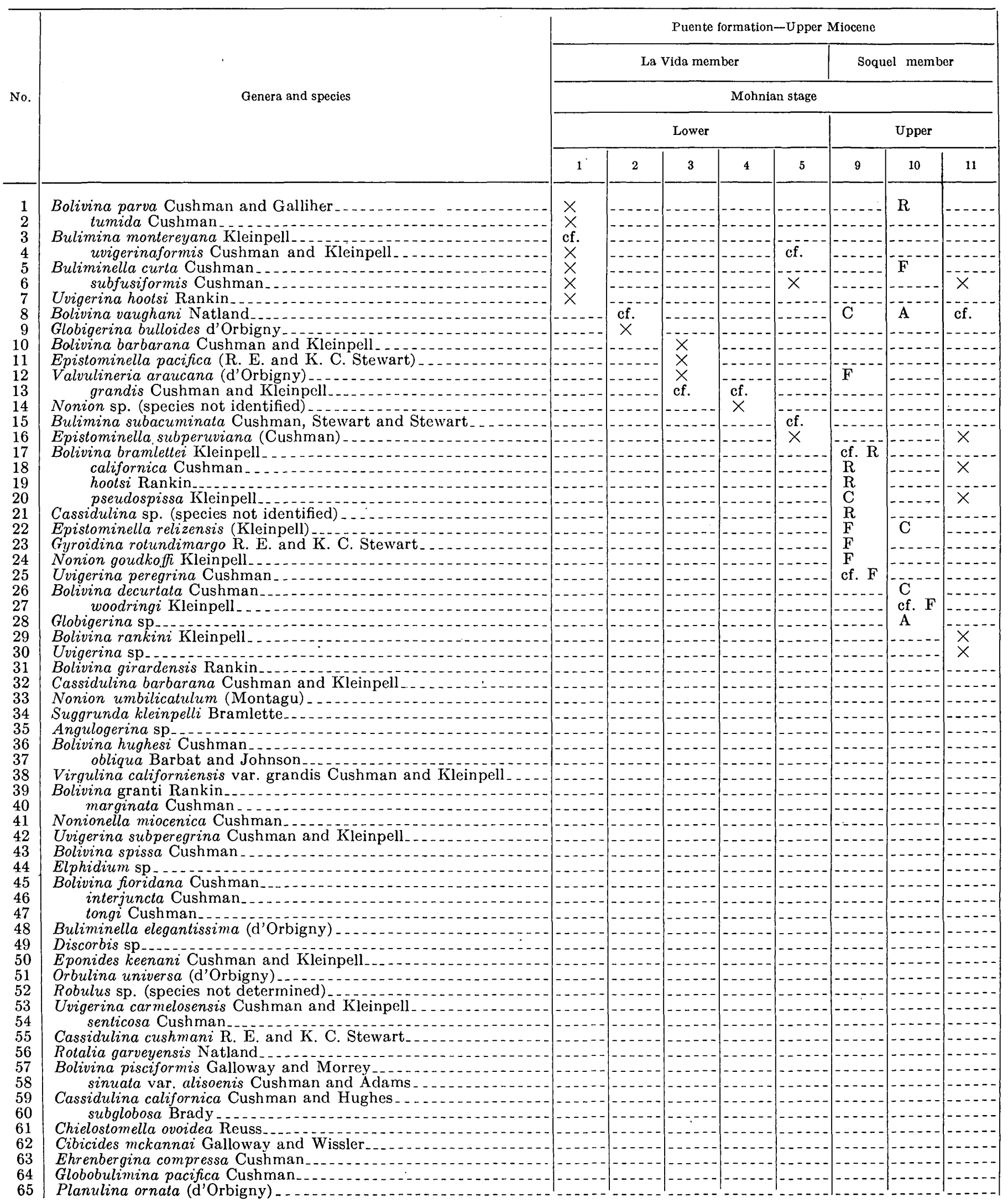


GEOLOGY AND OIL RESOURCES, EASTERN PUENTE HILLS

Puente and Fernando formations in the eastern Puente Hills area

F, frequent; C, common; R, rare; $X$, present; c., not certainly identifled, but resembling species listed. Numbered localities are shown on pl. 1]

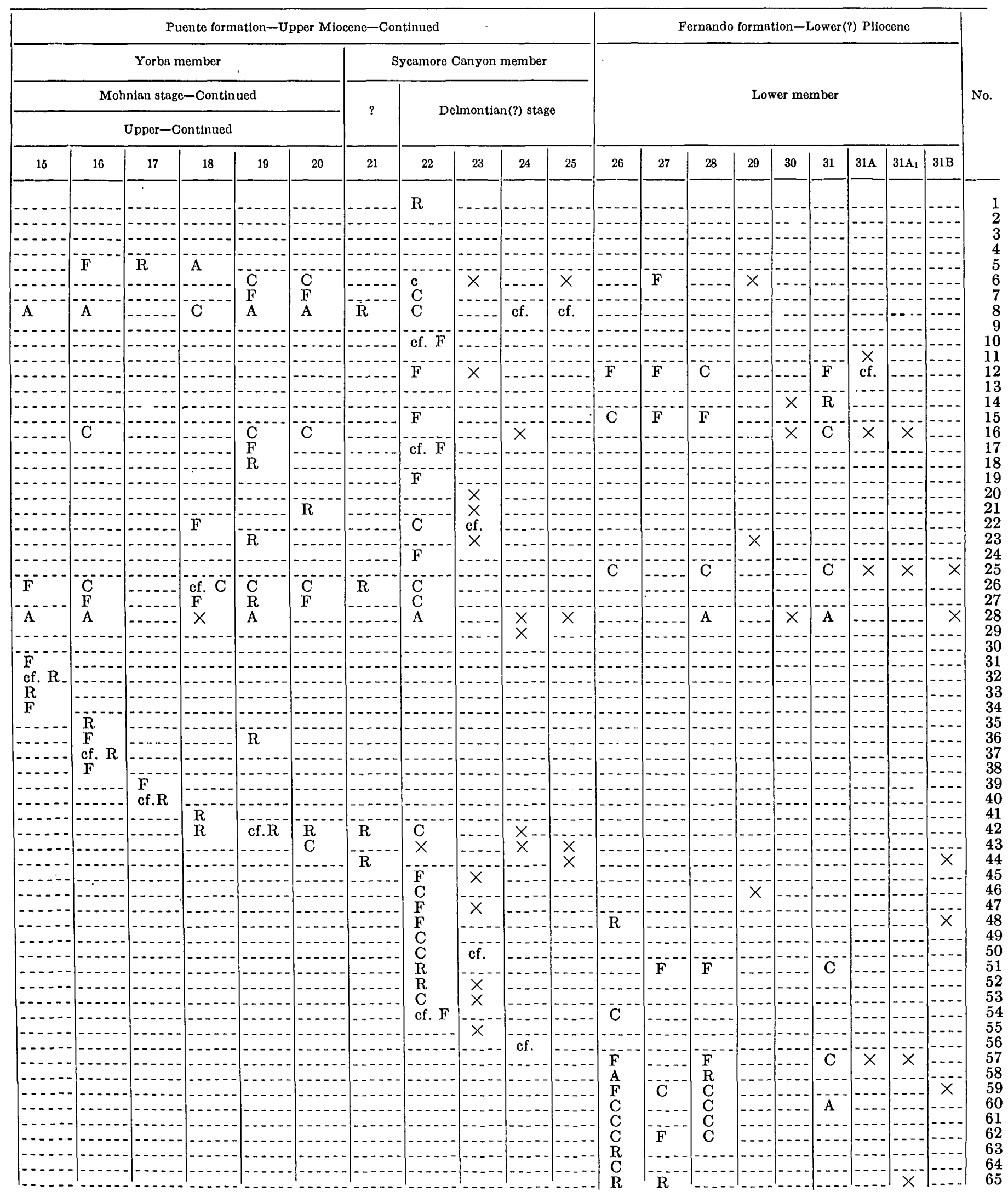


$\mathrm{T}_{\mathrm{ABLE}}$ 1.-Stratigraphic distribution of Foraminifera from the Puente and [Identiflcations by Patsy B. Smith, U.S. Geol. Survey. Symbols indicating abundance of species in samples containing a large fauna: A, abundant;

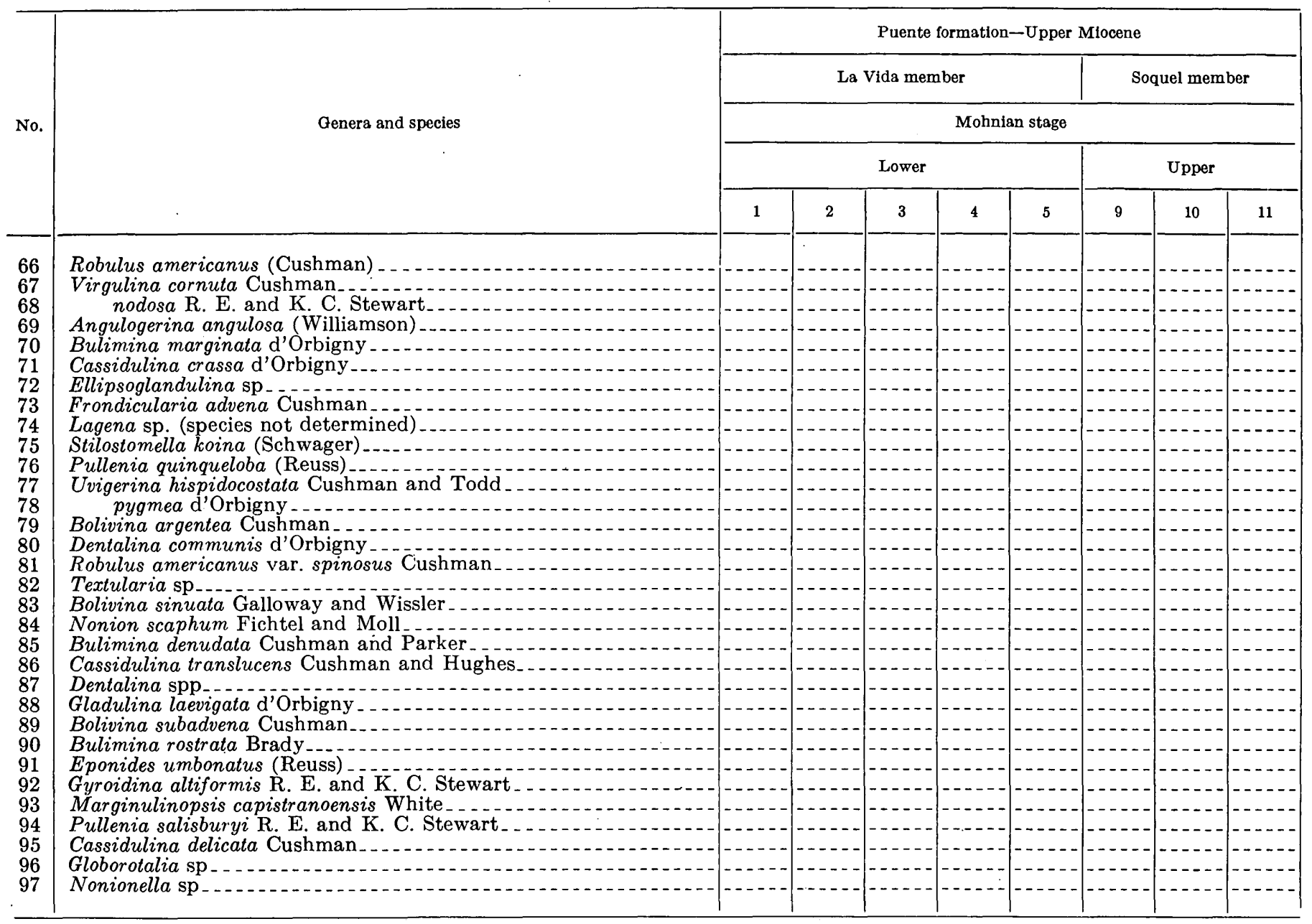

Note: The following list is an alphabetic key to the genera and species.

\begin{tabular}{|ll|rc|}
69 & Angulogerina angulosa & 58 & Bolivina sinuata var. alisoensis \\
35 & sp. & 43 & spissa \\
79 & Bolivina argentea & 89 & subadpena \\
10 & barbarana & 47 & tongi \\
17 & bramlettei & 2 & tumida \\
18 & californica & 8 & vaughani \\
26 & decurtata & 27 & woodringi \\
45 & foridana & 85 & Bulimina denudata \\
31 & girardensis & 70 & marginata \\
39 & granti & 3 & montereyana \\
19 & hootsi & 90 & rostrata \\
36 & hughesi & 15 & subacuminata \\
46 & interjuncta & 4 & uvigerimaformis \\
40 & marginata & 5 & Buliminella curta \\
37 & obliqua & 48 & elegantissima \\
1 & parva & 6 & subfusiformis \\
57 & pisciformis & 32 & Cassidulina barbarana \\
20 & pseudospissa & 59 & californica \\
29 & rankini & 71 & crassa \\
83 & sinuata & 55 & cushmani \\
& & &
\end{tabular}

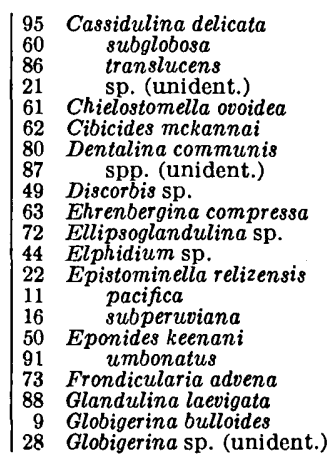


Fernando formations in the eastern Puente Hills area-Continued

F, frcquent; C, common; R, rare; $X$, present; cf., not certainly identifled, but resembling species listed. Numbered localities are shown on pl. 1]

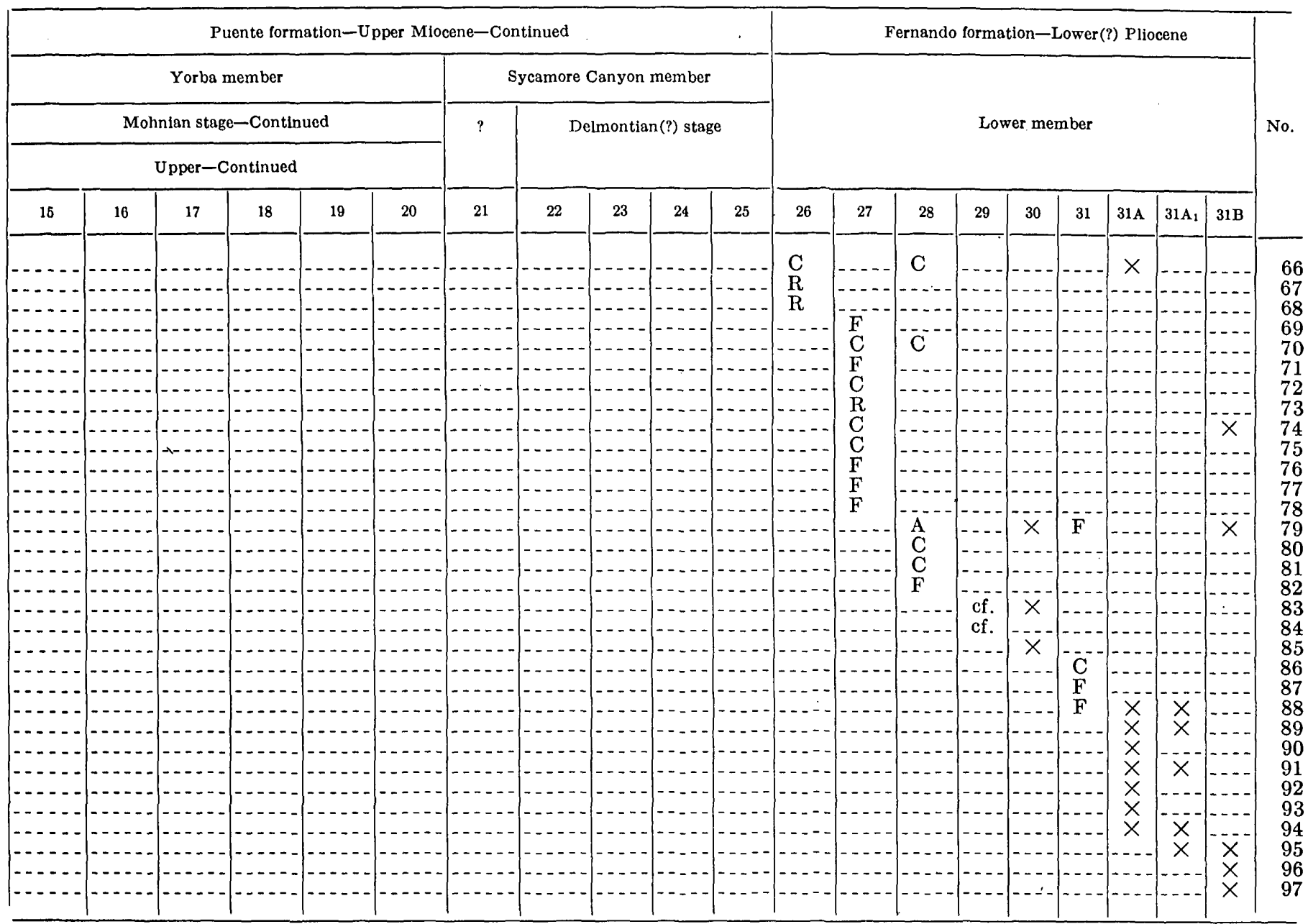
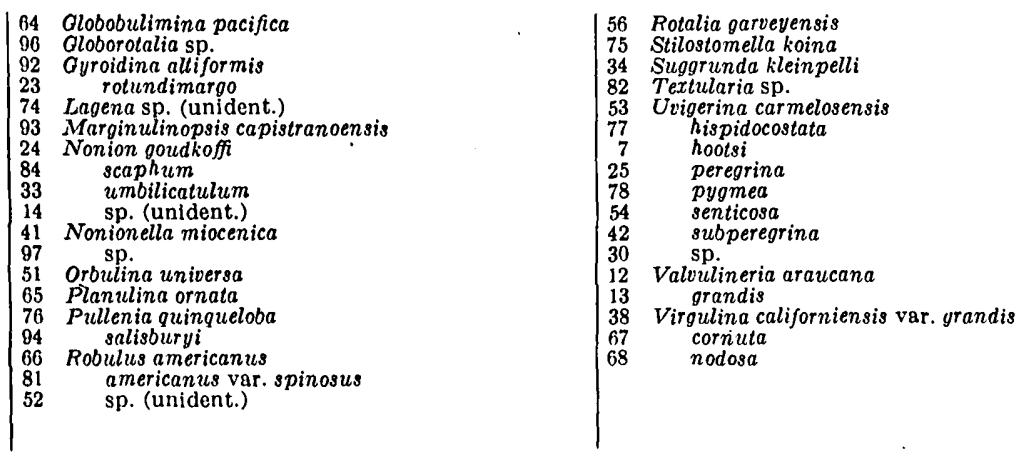


\section{Conditions of deposition}

The La Vida member is entirely of marine origin. Woodford and others (1946, fig. 10, p. 558) suggests that the shoreline of the sea in which the sediments of the La Vida member were deposited extended eastward just north of Glendora and turned southeastward between San Dimas and La Verne to the northwest corner of the city of Pomona. From there it extended southwestward between the San Jose and Puente Hills, turned southeast across the northeasternmost Puente Hills, and continued toward the Santa Ana River just northeast of the hills. Conglomerate in the La Vida member north of the Puente Hills contains types of rock that suggest a source area in the southeastern part of the San Gabriel Mountains and adjacent areas (Woodford and others, 1946, p. 553).

\section{SOQUEL MEMBER}

\section{D1stribution and character}

The Soquel member of the Puente formation was named by Schoellhamer and others (1954) for exposures in Soquel Canyon in the eastern Puente Hills. The member is well exposed near San Juan Hill, where both its base and its top are present in a thin but unfaulted sequence of beds. The member typically consists of massive to well-bedded medium- to coarse-grained or gritty feldspathic sandstone. At a few localities, particularly in the northern part of the map area and at Scully Hill, conglomerate and conglomeratic sandstone beds occur in the member. Ellipsoidal concretions are common in the lower part of the unit.

Sandstone beds in the Soquel member vary in thickness from a few inches to several feet (fig. 7), and they are ordinarily separated by thin beds or partings of siltstone. In a few places the sandstone is massive and almost structureless. The sandstone is gray and weathers to light brown. It is composed of quartz, plagioclase, varying amounts of biotite, and minor amounts of accessory minerals such as garnet, apatite, zircon, and magnetite-all in a clayey matrix. The sandstone is generally medium to coarse grained or even gritty, but locally it is fine grained. Graded beds, ordinarily a foot or less thick, are common. Most of the ungraded sandstone beds are poorly sorted. The weathered sandstone is friable, but fresh rock from well cores is well cemented. Several small outcrops of tar sand occur in the upper part of the Soquel member in the northeastern part of the Yorba Linda quadrangle.

A core of the Soquel member from the Shell Oil Co. well Menchego 12 (pl. 1, well 170; sec. 1, T. 3 S., R.10 W.) consists of light-gray massive dense sandstone. Almost all the interstices between grains of the sand- stone are occupied by crushed and bent shreds of biotite. In a thin section of this sandstone the grains are subangular to subrounded and range in size from 0.05 to $0.64 \mathrm{~mm}$, averaging $0.2 \mathrm{~mm}$, in largest dimension. The rock consists of about 50 percent andesine, 23 percent quartz, 13 percent biotite, 5 percent orthoclase, 4 percent pyrite, 3 percent chlorite, 1 percent muscovite, and 1 percent calcite and unidentified matrix.

The concretions that occur in the lower part of the member are ellipsoidal, from 1 to 5 feet in diameter, extremely hard, and cemented with calcite. They are composed of the same material, excepting matrix, as the sandstone in which they are embedded. In a few places bedding structures can be traced from the enclosing rock through the concretions, indicating that the concretions were formed by differential cementation of the sandstone in place. The concretions are distinguished from the enclosing rock by their greater hardness and darker color. They generally have a rough, gritty surface etched by weathering, so that the coarser sand grains stand in relief. The concretions are relatively resistant to weathering and ordinarily protrude from the outcrop and give it a knobby appearance. When the concretions fall free of the sandstone, they lie strewn about on the hillside or collect in gully bottoms, leaving large rounded cavities in the outcrops from which they came.

At Scully Hill the typically sandy Soquel member contains pebble and cobble conglomerate units as much as 4 feet thick, interbedded with coarse-grained sandstone units of similar thickness and containing siltstone beds. Boulders as much as 2 feet in diameter occur in these conglomerates. The larger clasts are chiefly of plutonic rock types, but some of the smaller ones are metamorphic and volcanic rocks. Near the center of the north margin of the Yorba Linda quadrangle, the Soquel member contains many large boulders of quartz diorite in siltstone and sandstone beds; these boulders are as large as 15 feet in longest dimension and evidently came from the area just southwest of Pomona where that plutonic rock is exposed.

In a few areas, as near the head of Carbon Canyon, the upper part of the Soquel member contains an unusually large percentage of siltstone. At these places the siltstone occurs as thick units, in contrast to the thin siltstone interbeds that are more common in the member. The siltstone is lithologically similar to that in the adjacent members.

\section{Th1ckness}

South of the Whittier fault zone, the Soquel member is thickest in the area between the Union Oil Co. well Graham-Loftus 1 in the East Coyote oil field (pl. 4) and the Union Oil Co. well Chapman 29 in the Richfield oil field (pl. 4). It is more than 2,400 feet thick 
at the East Coyote oil field, 2,695 feet thick at the Richfield oil field, and about 1,000 feet thick at the Esperanza oil field (pl.4). North of the Whittier fault zone the member is about 2,000 feet thick at the ChinoSoquel oil field and about 3,000 feet thick in the northeastern part of the Yorba Linda quadrangle (pl. 4).

Fossils

Fossils are scarce in the Soquel member. Only a few shell and bone fragments, shark teeth, and unidentifiable carbonized organic remains have been found in the sandstone beds of the member in the eastern Puente Hills. One coral and several genera of marine mollusks are recorded from the pebbly sandstone at the base of the member north of the map area at the northern tip of the Puente Hills (Woodford and others, 1946, p. 535). Siltstone interbedded with the sandstone more typical of the member contains $\mathrm{Fo}_{\mathrm{O}}$ raminifera at a few localities. Foraminiferal faunas from the Soquel member are listed in table 1, and fossil localities are shown on plate 1 .

Foraminifera from the Soquel member at localities $\mathrm{f}-7, \mathrm{f}-12, \mathrm{f}-13$, and $\mathrm{f}-14$ were collected and identified by M. N: Bramlette, who assigned the fauna from localities $\mathrm{f}-7$ and $\mathrm{f}-12$ to the Bulimina uvigerinaformis zone of the lower Mohnian stage and those from localities $\mathbf{f}-13$ and $\mathrm{f}-14$ to the Bolivina hughesi zone of the basal upper Mohnian stage (Bramlette, written communication).

\section{Age and stratigraphic relations}

Foraminiferal faunas from siltstone of the Soquel member in the eastern Puente Hills are indicative of the Mohnian stage, and usually of the upper Mohnian stage of late Miocene age.

Both the upper and the lower contacts of the Soquel member appear to eross time-stratigraphic horizons. The contacts are gradational in vertical detail, for the changes in lithologic character that mark the boundaries of the member ordinarily occur in a stratigraphic interval of as much as 50 feet. The lower contact of the member is well exposed on the west side of San Juan Hill and in Carbon Canyon, near La Vida Mineral Springs (fig. 7). The upper contact is well exposed in roadcuts in the northwest quarter of sec. $8, \mathrm{~T} .3 \mathrm{~S}$., R. 8 W., and east of the center of sec. 15, T. 2 S., R. $9 \mathrm{~W}$.

\section{Conditions of deposition}

Fossils in the Soquel member indicate that it is at least in part of marine origin. The composition of conglomerate beds in the member suggests that they were derived from a nearby northeastern source area (Woodford and others, 1946, p. 554). The occurrence of many widespread sandstone beds throughout the member and of large boulders in relatively fine grained rocks at the top of the unit suggests that turbidity currents may have played a part in its deposition. Woodford and others (1946, p. 558) postulate that the shoreline of the sea in which the sediments of the Soquel member were deposited trended eastward from the San Gabriel Valley to the southern edge of San Dimas, turned southeastward almost to Elephant Hill, passed between Elephant Hill and Pomona, and continued toward the Santa Ana River.

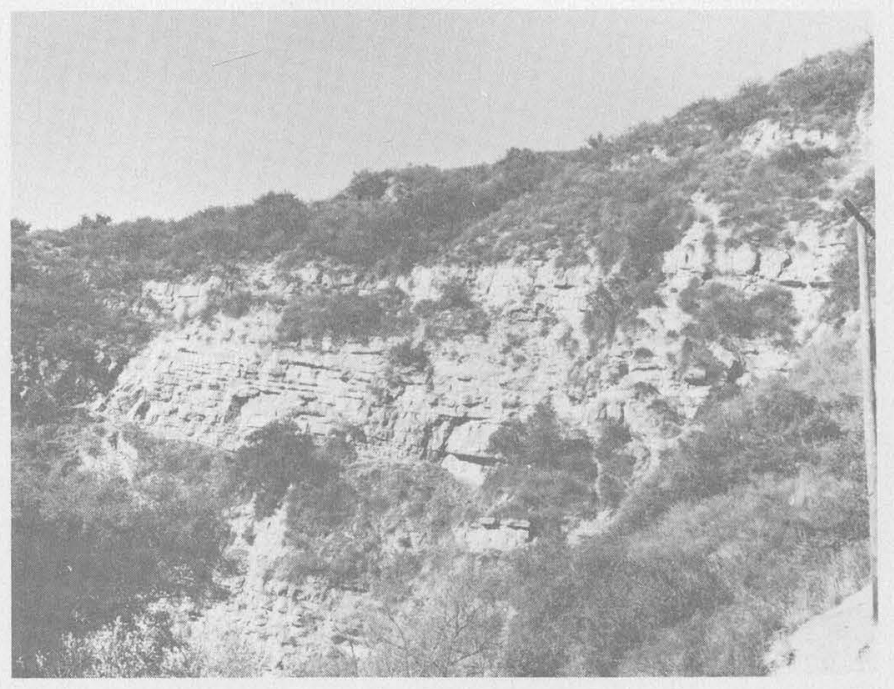

FIGURE 7.-Thick-bedded sandstone unit that marks the base of the Soquel member of the Puente formation in Carbon Canyon, near La Vida Mineral Springs.

YORBA MEMBER

Distribution and character

The Yorba member was named by Schoellhamer and others (1954) for Yorba Bridge, which spans the Santa Ana River $2 \frac{1}{2}$ miles east of the community of Atwood. In the eastern Puente Hills, the Yorba member is best exposed along the west edge of the Prado Dam quadrangle and in the northeastern part of the Yorba Linda quadrangle. A complete section of the member, including both its top and its base, is exposed 2 to 3 miles southwest of Los Serranos.

The Yorba member generally consists of thin-bedded pinkish-brown to gray or nearly white siltstone with a hackly fracture, containing subordinate amounts of fine-grained sandstone. Much of the siltstone is siliceous, platy, and extremely hard, but softer and less well bedded siltstone is also common. Siltstone with paper-thin laminations is characteristic and prominent in the member at many localities (fig. 8). Siltstone of the Yorba member is commonly contorted and crumpled, and on hillsides it tends to creep and slump. Siliceous siltstone with a cherty appearance occurs in the Yorba member at a few localities, as in Slaughter 
Canyon near the Chino fault. Gray limy concretions that weather white are common in the siltstone, and thin white or yellowish limestone beds occur at a few places. Sandstone is present in the Yorba member, both as thin beds separated by siltstone laminae and as thicker beds in siltstone units (fig. 9). South of the Bryant Ranch fault the Yorba member contains more sandstone than is usual for the unit. Some of this sandstone is coarse, massive, and otherwise similar to that of the Soquel member, but it is included in the Yorba member because of its stratigraphic position.

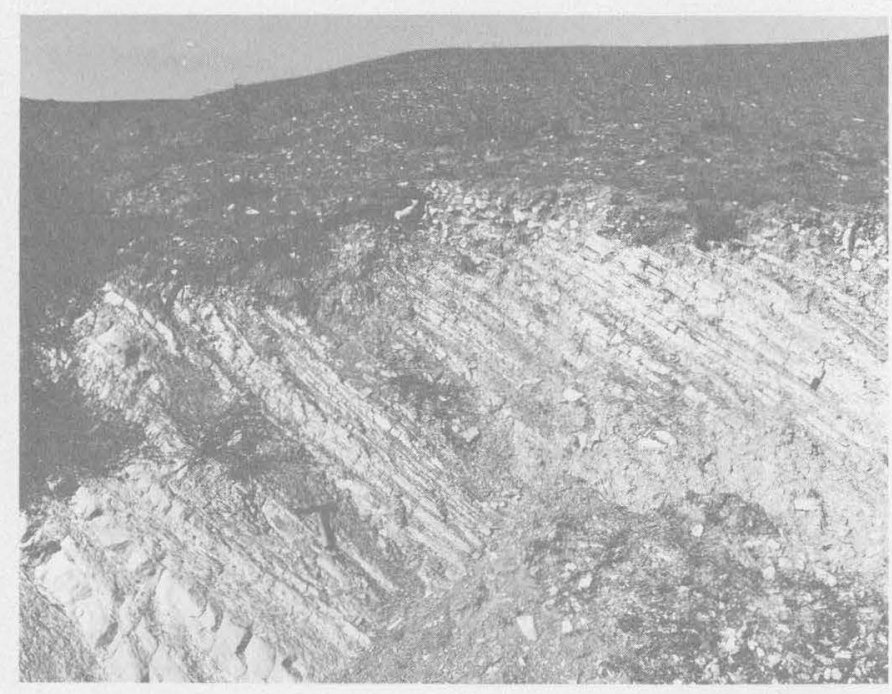

Figure 8.- Siltstone and thin sandstone beds of the Yorba member of the Puente formation exposed in a roadcut on the south side of San Juan Hill.

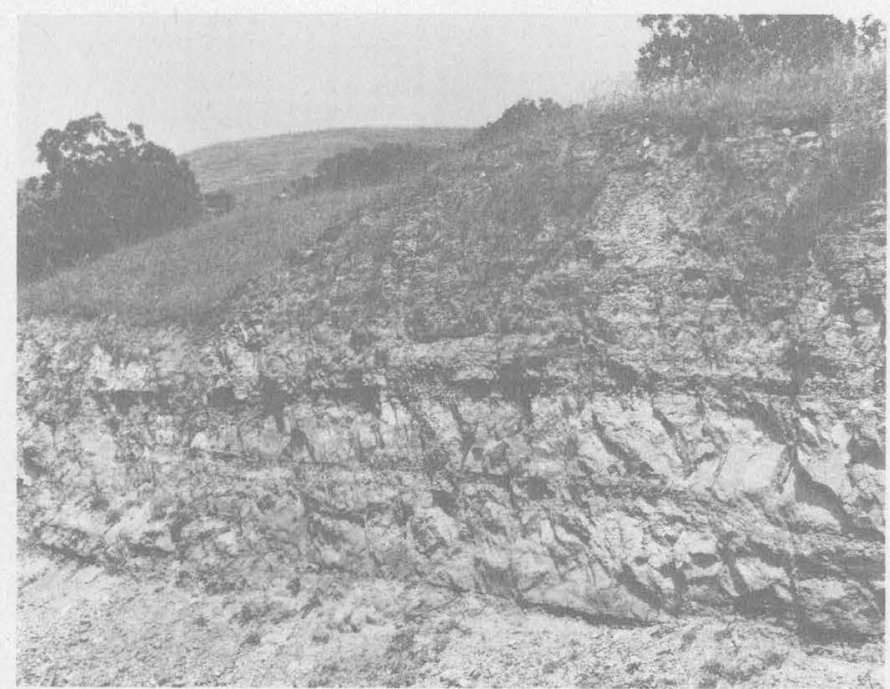

FigURE 9.-Thick-bedded sandstone in siltstone of the Yorba member of the Puente formation exposed in a pipeline cut in sec. 24, T. 2 S., R. $9 \mathrm{~W}$.

\section{Thickness}

South of the Whittier fault zone, the Yorba member attains a thickness of about 3,000 feet in the area between the southeast corner of the Yorba Linda quadrangle and the Brea-Olinda oil field. The entire thickness of the unit is not exposed north of the Whittier fault zone in the Yorba Linda quadrangle. The member is about 2,000 feet thick in the central part of the Prado Dam quadrangle and about 2,300 feet thick near the Bryant Ranch anticline (pl. 4). The member is only about 275 feet thick where it overlies granitic basement rocks east of the Chino basin (pl. 3).

\section{Fossils}

Foraminifera are abundant in the Yorba member at only a few places in the eastern Puente Hills. Faunas from the Yorba member are listed on the checklist of Foraminifera (table 1). A fauna collected by M. N. Bramlette from the Yorba member at locality $\mathrm{f}-20-\mathrm{A}$ was assigned by him to the Bolivina hughesi zone of the upper Mohnian stage (written communication).

Foraminifera collected from the Yorba member in the San Juan tunnel between 1,800 and 2,500 feet from the east portal (fig. 19) consist almost entirely of Bolivina ef. B. vaughani Natland and Globigerina bulloides d'Orbigny, and indicate a probable deep-water open-sea environment of deposition for the rocks. Between 2,800 and 3,200 feet from the east portal of the tunnel the Yorba member contains the fauna listed below, which is characteristic of Kleinpell's Botivina hughesi zone of the upper Mohnian stage and suggestive of a water depth of about 2,000 feet (Patsy B. Smith, written communication, 1957).

Bolivina sinuata Galloway and Wissler spissa Cushman

Uvigerina subperegrina Cushman and Kleinpell

Gyroidina rotundimargo R. E. and K. C. Stewart

Anomalina hughesi Rankin

Globigerina bulloides d'Orbigny

Age and stratigraphic relations

Foraminifera in the Yorba member in the eastern Puente Hills belong chiefly to the Bolivina hughesi zone of the upper Mohnian stage of Kleinpell. The member has gradational contacts with both the underlying Soquel member and the overlying Sycamore Canyon member. The basal contact of the Yorba member is well exposed southwest of Los Serranos in the northwest quarter of sec. 8 , T. 3 S., R. 8 W., and also in roadcuts in sec. 15, T. 2 S., R. 9 W. The upper part of the Yorba member probably interfingers with the Sycamore Canyon member south of Los Serranos along the Ridge syncline (pl. 3).

At the Richfield oil field the Yorba member contains an unusually high proportion of sandstone that forms 
a reservoir for oil ("Chapman sand"). In the subsurface southwest of the Richfield oil field the member cannot be differentiated from the La Vida member because of the absence there of the Soquel member.

\section{Conditions of deposition}

Siltstone in the Yorba member contains Foraminifera indicating that it was deposited in a marine environment, probably at water depths of 1,800 feet or more. The prevailing sedimentation of mud and silt was interrupted occasionally by the introduction of sand, which was probably carried from shallower depths by turbidity currents and deposited as widespread graded beds.

SYCAMORE CANYON MEMBER

\section{Distribution and character}

The Sycamore Canyon member was named by Daviess and Woodford (1949) for exposures in Sycamore Canyon near the western end of the Puente Hills. The thickest and best exposed section of the member in the eastern Puente Hills is near Prado Dam. Its base is well exposed near the southwest corner of sec. 23, T. 3 S., R. 8 W.; its top is exposed near the north edge of sec. 15 , T. 3 S., R. 9 W., where siltstone of the lower member of the Fernando formation overlies conglomerate correlated with the Sycamore Canyon member.

The Sycamore Canyon member is well exposed on the western flank of the Mahala anticline in Slaughter Canyon. There the basal unit of the member consists chiefly of light-brown to light-gray friable thick-bedded to massive medium- to coarse-grained sandstone. Locally, especially farther south, the sandstone is thin bedded and has partings of siltstone. The sandstone contains scattered ellipsoidal limy concretions similar to those in other sandstone units in the Puente formation. South of Slaughter Canyon the basal sandstone unit contains well-rounded pebbles, cobbles, and boulders of plutonic and metamorphic rocks, both as isolated clasts and in lenses.

Stratigraphically above the basal sandstone unit in Slaughter Canyon is a sequence of fine-grained thinbedded platy siliceous siltstone and poorly exposed friable poorly bedded sandy micaceous siltstone beds. The siltstone is generally gray and contains minor amounts of fine- to medium-grained feldspathic sandstone occurring as thin interbeds. The siltstone also contains seattered limestone concretions that weather white or yellowish white. Southward from Slaughter Canyon, this siltstone unit grades into sandstone and conglomerate like that in the underlying and overlying units.
The third unit above the base of the Sycamore Canyon member in Slaughter Canyon consists of sandstone and lesser amounts of siltstone and conglomerate. Northwest of Slaughter Canyon, this sandstone is finer grained and grades into siltstone; southeast of Slaughter Canyon, it is coarse grained and conglomeratic. The sandstone is feldspathic, light brown, and friable. The pebbles, cobbles, and occasional boulders in the conglomerate are well rounded and similar in composition to those in conglomerates lower in the member.

The youngest strata exposed along the Ridge syncline near Slaughter Canyon consist of sandstone and sandy siltstone with prominent conglomerate beds. Although much of the conglomerate occurs in relatively thin but extensive beds, some also occurs as thick, podlike beds or lenses. The matrix of the conglomerate is usually fine-grained silty micaceous sandstone, much like the adjacent sandstone beds. Scattered pebbles and cobbles also occur in siltstone of the unit. The larger clasts of the conglomerates are chiefly pebbles of plutonic and metamorphic rock with a few volcanic rocks.

A thick and conspicuous unit of nearly white conglomeratic sandstone is exposed northwest of Prado Dam along the axis of the Arena Blanca syncline (fig. 10). This white sandstone unit contains the youngest beds exposed in the Sycamore Canyon member in this area, and it may include some that are of Pliocene age. Near the base, this unit consists of alternating beds of white sandstone and gray or greenish-gray siltstone ranging from a few inches to several feet in thickness. Higher in the section, and toward the east, the unit consists almost entirely of massive white

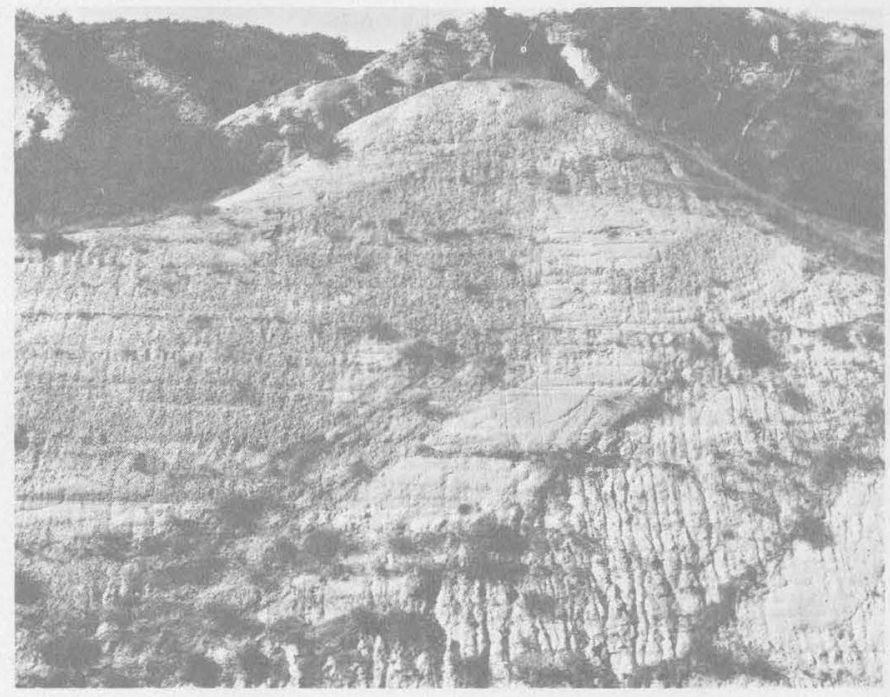

Figure 10.-White pebbly sandstone of the Sycamore Canyon member of the Puente formation exposed in a highway cut just north of Prado Dam. The beds dip to the left (south) and show cut-and-fill features. The road cut is about 25 feet high. 
sandstone with poorly defined beds and lenses of conglomerate and scattered individual pebbles and cobbles. West of Prado Dam the white sandstone is interbedded with siltstone. The sandstone is medium to coarse grained, feldspathic, and poorly sorted. The sand grains are generally less well rounded than is usual in sandstone of the Puente formation.

The Sycamore Canyon member is exposed in the Yorba Linda quadrangle only south of the Whittier fault zone, where it consists of steeply dipping sandy siltstone and sandstone beds. Lenses of pebble and cobble conglomerate are interbedded with the sandstone and siltstone. The pebbles and cobbles are subrounded to well rounded and consist chiefly of resistant crystalline rocks. Pebbly sandstone, conglomerate, and mudstone beds of the Sycamore Canyon member are well exposed in the ridge just south of the bend in Tonner Canyon (fig. 11).

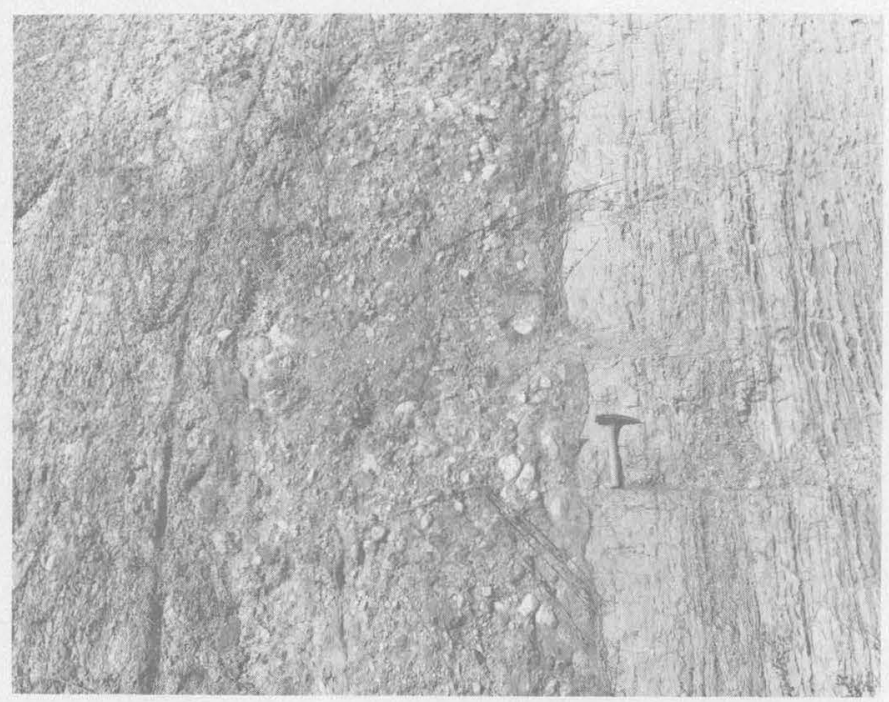

FIGTRE 11.-Vertical beds of pebbly sandstone and mudstone of the Sycamore Canyon member of the Puente formation exposed in a cut south of Tonner Canyon in the Brea-Olinda oil field.

Northeast of the Chino fault, strata assigned to the Sycamore Canyon member are lithologically similar to parts of the member exposed southwest of the Chino fault on the Mahala anticline. Because of structural complications and lack of distinctive lithologic markers, units within the Sycamore Canyon member have not been correlated across the Chino fault.

\section{Thickness}

A complete section of the Sycamore Canyon member is not exposed in the eastern Puente Hills. The member is 3,500 feet thick at the southern end of the Ridge syncline and no more than 1,100 feet thick 2 miles farther north on the western flank of the same structural feature. The conglomerate unit marking the base of the member at the southern end of the syncline pinches out to the north, where a stratigraphically higher conglomerate unit is at the base. East of the Chino fault in the northern part of the Chino basin the Sycamore Canyon member is about 1,500 feet thick (pl. 3). Near the southeast corner of the Prado Dam quadrangle, it may exceed 3,600 feet in thickness (pl. 4).

The Sycamore Canyon member is 1,650 feet thick near the southeast corner of the Yorba Linda quadrangle (pl. 4) and is only about 500 feet thick in the Brea-Olinda oil field (pl. 3). The member is unusually thin near the southwest corner of the Yorba Linda quadrangle, and at the Richfield oil field it is only 175 feet thick (pl. 3). The member pinches out along a line trending about N. $60^{\circ} \mathrm{W}$. near the southwest corner of the Yorba Linda quadrangle.

Fossils

Foraminifera are scarce or absent in exposures of the Sycamore Canyon member in most of the eastern Puente Hills, but they are common in fresh samples from wells or excavations. Foraminiferal faunas collected from the Sycamore Canyon member in the eastern Puente Hills are listed on the checklist of Foraminifera (table 1).

The San Juan tunnel penetrated the basal 900 feet of the Sycamore Canyon member (fig. 19). Samples from the member in the tunnel contain the following composite foraminiferal fauna, characteristic of Kleinpell's Bolivina hughesi zone (upper Mohnian) of late Miocene age (Patsy B. Smith, written communication, 1957):

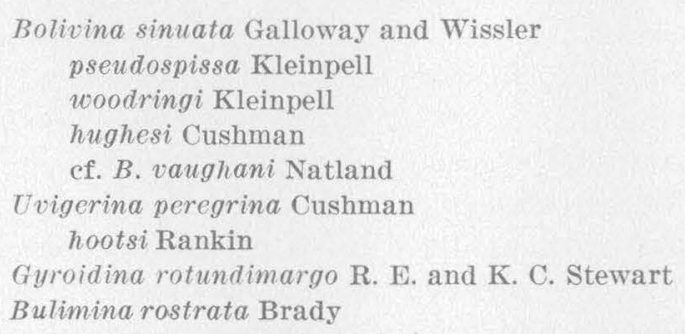

\section{Age and stratigraphic relations}

Foraminiferal faunas from the Sycamore Canyon member indicate that it is at least in part of late Miocene age. In the type area in the western Puente Hills, the uppermost part of the member is apparently barren of diagnostic fossils, but a good upper Mohnian fauna occurs 1,035 feet below the top (Wissler, 1943, p. 223). In the eastern Puente Hills, foraminiferal faunas from the member are of late Mohnian and Delmontian(?) age. The upper part of the member near Prado Dam contains foraminiferal faunas described by Stewart and Stewart (1930) as of early Pliocene age. Kleinpell (1938, p. 28-32) reviewed this age determination and pointed out that the assemblages may belong to a Miocene-Pliocene transition fauna. Strata de- 
scribed as of Pliocene age were mapped in the Arena Blanca and Ridge synclines and northeast of the Chino fault by Woodford and others (1944), but a mappable unit of Pliocene age in that area was not distinguished by Durham and Yerkes.

The Sycamore Canyon member is distinguished from the underlying Yorba member by the presence of conglomerate beds in the Sycamore Canyon member. In the northwest quarter of sec. 15 and the southwest quarter of sec. 10, T. 3, S., R. 8, W., the basal unit of the Sycamore Canyon member is sandstone rather than conglomerate, but the unit can still be differentiated. A unit of coarse-grained rock marking the base of the Sycamore Canyon member is apparently absent in the area south of Los Serranos, where distinction of siltstone of the Yorba member from that of the Sycamore Canyon member is arbitrary. Farther south, on the flanks of the Ridge syncline, the contact between the Sycamore Canyon and Yorba members can be readily mapped. In the subsurface, however, the basal sandstone unit of the Sycamore Canyon member on the eastern flank of the syncline either pinches out or is faulted off before reappearing on the western flank. The mappable base on the western flank, which is a podlike lens of conglomerate and sandy conglomerate, may be the correlative of the second sandstone unit above the base on the eastern flank (pl. 3). Consequently, the lower siltstone unit of the Sycamore Canyon member on the eastern flank of the Ridge syncline may be the correlative of the upper part of the Yorba member on the western flank of the syncline, the lowermost sandstone unit being absent there. All the sandstone and conglomerate units in the Sycamore Canyon member near the Ridge syncline become finer grained and grade into siltstone toward the north.

\section{Conditions of deposition}

The Sycamore Canyon member in the eastern Puente Hills is considered to be entirely of marine origin. The beds of white pebbly sandstone near Prado Dam may have been deposited near or at the shoreline, but foraminiferal faunas collected from the member in the San Juan tunnel area suggest water depths greater than 2,000 feet. The interfingering of beds of coarse-grained and fine-grained rock and the occurrence of widespread graded sandstone beds suggest deposition by turbidity currents. The general coarsening of the Sycamore Canyon member to the north and east in the southeastern part of the Puente Hills may indicate a northeastern source area for the sediments. Woodford and others (1946, p. 556), who made a study of the rock types represented in conglomerates of the Sycamore Canyon member in the western Puente Hills, concluded that those rocks may have been de- rived from a wide arc of land area to the north and east, including the southeastern San Gabriel Mountains, which were the source of a distinctive mylonite gneiss. Bedding features exposed in the San Juan tunnel suggest a northeastern source for strata of the Sycamore Canyon member in that area (p. B59).

DIABASIC INTRUSIVE ROCKS ASSOCIATED WITH THE PUENTE AND OLDER FORMATIONS

\section{Distribution and occurrence}

Intrusive rocks of middle to late Miocene age occur in several wells drilled along the Whittier fault zone. The rock is generally diabasic and locally very coarse grained. It ranges in composition from gabbro to diorite. Surface exposures and the known subsurface extent the diabase are spatially related to the Whittier fault zone. The diabase probably was intruded along the fault zone and was cut by later movement on the fault. With a single known exception, the diabase occurs only within or north of the fault zone. This exception is at the Richfield Oil Corp. well Edwards 1, located west of the Yorba Linda quadrangle 3 miles south of the fault zone in sec, 15, T. 3 S., R. 10 W. This well penetrated about 60 feet of altered diabase at a depth of 9,250 feet. The diabase in the well overlies red beds of the Vaqueros and Sespe formations undifferentiated, of late Eocene to early Miocene age, and is overlain by strata of the La Vida member of the Puente formation of early late Miocene age. Sill-like intrusions as much as 650 feet thick were found in other wells drilled as far as 1.6 miles north of the Whittier fault.

Diabase crops out just north of the Whittier fault zone near the mouth of Wireline Canyon, 3,000 feet west of the west border of the Yorba Linda quadrangle. It occurs as a thick sill-like body exposed for 3,400 feet along the fault zone. Only the upper contact is exposed. It is overlain by a sequence of locally altered and baked siltstone beds about 250 feet thick, which is in turn overlain by a second, much thinner and less persistent sill of diabase. The diabase is intensely altered, dark grayish green to olive green, and locally vesicular. It commonly has chilled margins as much as 1 foot thick.

The two diabase bodies that crop out in Wireline Canyon were penetrated by several wells in the central part of the Yorba Linda quadrangle, north of the Whittier fault zone (pl. 1, wells 140, 167, 169, 170, 184, 221, $240,253)$. The intrusive body extends in the subsurface for 9 miles from Wireline Canyon to the eastern edge of the Yorba Linda quadrangle, north of the Whittier fault zone, and has a width of about 2 miles. The diabase body strikes about N. $40^{\circ}$ W. and dips about $16^{\circ} \mathrm{SE}$. It evidently cuts across about 4,000 
feet of section from a position low in the La Vida member of the Puente formation at the west (pl. 3 ) to a stratigraphically lower position in the Topanga formation at the east (pl.4).

All the diabase bodies are approximately contemporaneous. The diabase was probably intruded along the Whittier fault zone and spread laterally near the surface to form cross-cutting sills.

\section{Petrography}

The intrusive rocks of the eastern Puente Hills are similar lithologically and suggest a common source. The variations that occur are chiefly in texture, secondary minerals, and degree of alteration. The intrusive rocks are usually dark grayish green and considerably altered and have a moderately coarse to very coarse ophitic texture. In thin sections of the rock, plagioclase ranges in composition from andesine to labradorite and occurs as slightly to intensely altered but well-developed 1- to 2-mm laths and tablets that have albite and Carlsbad twinning. Interstitial augite, although always present, is seldom fresh; in a core from depths between 5,199 and 5,202 feet in the Shell Oil Co. well Wright 73-18 (pl. 1, well 184; sec. 18, T. 3 S., R. 8 W.) augite formed from olivine. Orthorhombic pyroxene (mostly hypersthene) commonly occurs in small amounts. Olivine, both fresh and altered, is present in cores from the Shell Oil Co. well Wright 73-18 but has not been found elsewhere in the area. Ilmenite, occurring as small scattered grains and plates, is conspicuous in all samples of the intrusive rock. Secondary minerals include hornblende, oxyhornblende, reddish-brown biotite, and rarely quartz. Apatite is a minor accessory in several samples; chlorite occurs as an alteration product; and calcite veins cut many of the samples.

\section{Age}

Intrusive rocks in the eastern Puente Hills are known to occur only in strata of the Topanga formation of middle Miocene age and in strata of the La Vida member of early late Miocene age. Siltstone containing Foraminifera of the late Mohnian (early late Miocene) stage overlies diabase in several wells along the Whittier fault zone. The intrusion is therefore no older than late Mohnian.

The upper age limit of the intrusion cannot be determined precisely. The oldest strata in which clasts of the intrusive rocks occur are conglomerate beds of the upper member of the Fernando formation (Pliocene). Diabase debris has not been identified in conglomerate of the Puente formation; this absence indicates that the intrusive rocks were either not present or not exposed at the time (latest Miocene) sediments of the Sycamore Canyon member were deposited. In the western Puente Hills, diabase pebbles and cobbles occur in conglomerate of the lower member of the Fernando formation which is exposed south of the Whittier fault zone, and clasts of diabase are commonly present in younger Pliocene strata. The intrusive rocks are certainly younger than the volcanic rocks of the Luisian stage (late middle Miocene), for they intruded the La Vida member of the Puente formation, which overlies the volcanic rocks. The intrusive rocks are most probably of the Mohnian stage (early late Miocene).

\section{PLIOCENE SERIES}

FERNANDO FORMATION

The Pliocene rocks of the Los Angeles basin have a complicated nomenclatural history. The name Fernando formation was introduced by Eldridge and Arnold (1907) for the Pliocene strata of the Los Angeles and Ventura basins, the type area being on the northwest side of the San Fernando Valley (fig. 1). English (1914) used the term Fernando group informally, and Kew (1924) proposed it formally for the Ventura basin deposits. Kew included the Pico formation of Pliocene age and the Saugus formation of Pliocene and Pleistocene age in his Fernando group. The type areas of both formations are in the eastern Ventura basin. English (1926) used the term Fernando group for the Pliocene rocks and for part of the underlying Sycamore Canyon member of the Puente formation in the Puente Hills. After Kew's report on the Ventura basin was published, the Pliocene rocks of the Los Angeles basin were assigned to the Pico formation by geologists working in that area. Iater study of Foraminifera from the Los Angeles basin showed that two distinct biostratigraphic units are represented in the Pliocene rocks of that area; however, study of the microfauna of the Pico formation at the type area in the Ventura basin suggested that the lower of these two biostratigraphic units is not present there (Wissler, 1943, p. 212). A committee of the Society of Economic Paleontologists and Mineralogists was formed to resolve this paradox, and in 1930 it proposed a twofold subdivision of the Pliocene section of the Los Angeles basin. The new name Repetto formation was given to the lower part of the section and the term Pico formation was retained for the upper part (Reed, 1932, p. 31, footnote). A type section for the Repetto formation was designated in the Repetto Hills (fig. 1) along the west side of Atlantic Boulevard, where the most complete outcrop sequence of Pliocene rocks in the Los Angeles basin was exposed.

General agreement on an upper and a lower boundary for the Repetto formation at the type section was never achieved, for the Pliocene rocks there cannot be divided on the basis of lithologic character. An almost 
continuous section of Pliocene strata was exposed in excavations made after 1955 along the Monterey Pass Road in the Repetto Hills, less than 1 mile west of the type section of the Repetto formation. The beds along the Monterey Pass extend from near the base to the top of the Pliocene series, but they cannot be divided on the basis of lithologic differences (Woodford and Schoellhamer, written communication, 1958). Similarly, in much of the subsurface of the Los Angeles basin, the Pliocene strata cannot be divided into formations but only into biostratigraphic units based chiefly on foraminiferal faunas. Most of the nomenclatural problems of the Pliocene rocks of the Los Angeles basin would therefore be simplified by assigning these rocks a single formational name. The name Pico is unsatisfactory because in the Los Angeles basin it is associated with a biostratigraphic rather than a lithologic unit, and the name has been restricted by common usage to rocks of late Pliocene age although the type section of the Pico formation in the Ventura basin may contain fossils of both early and late Pliocene age (Winterer and Durham, 1962, p. 322). The Pico formation is herein restricted to areas outside of the Los Angeles basin and is taken out of the Fernando group, which is reduced in rank to formation status. The name Repetto is also unsatisfactory because it is associated with a biostratigraphic rather than a lithologic unit and is therefore abandoned. The older name Fernando is suitable, however, and the Pliocene rocks in the eastern Puente Hills are ass: , wl to the Fernando formation in this report. In the Puente Fills and most of the eastern Los Angeles basin the formation is divisible into upper and lower members.

\section{D1stribution and character \\ LOWER MEMBER}

In the Prado Dam and Yorba Linda quadrangles, the lower member of the Fernando formation occurs only southwest of the Whittier fault zone. On the ridge south of Tonner Canyon, just southwest of the Whittier fault, the lower member consists mainly of siltstone that is light grayish brown to olive brown, commonly massive to poorly bedded, and micaceous. A few thin beds or partings of olive-gray claystone and thin beds of light-brown to olive-gray fine-grained silty sandstone also occur in the member. Interbedded with these fine-grained strata are several thin strikingly lenticular pebble conglomerate beds that form prominent outcrops. The pebbles in the conglomerate beds are well rounded, consist almost entirely of hard plutonic and metamorphic rocks, and range from 1 to 5 inches in longest dimension, averaging about 2 inches. Southeast of Olinda the lower member consists almost entirely of gray to light-brown poorly bedded micaceous siltstone and minor amounts of finegrained feldspathic sandstone. Both the sandstone and the siltstone commonly contain small angular chips of black charcoallike organic material.

\section{Thickness}

The lower member of the Fernando formation has an exposed thickness of 1,200 feet on the ridge south of Olinda (pl. 3). It thickens westward and is 2,300 to 2,600 feet thick on the ridge south of Tonner Canyon (pl. 3). It thins southward, probably because of the erosion of beds from its upper part prior to deposition of the upper member, and is only about 700 feet thick at the crest of the anticline at the Richfield oil field.

Fossils

Megafossils were collected from the lower member of the Fernando formation at only one locality (F-6) in the eastern Puente Hills. The locality is at or near the top of the member. The fauna was identified by J. G. Vedder, of the Geological Survey. Foraminifera are locally abundant in the member and faunas from nine localities in the eastern Puente Hills are given in table 1. Fossil localities are shown on plate 1.



Age and stratigraphic relations

The lower member of the Fernando formation overlies the Puente formation of late Miocene age and corresponds approximately to the Repetto formation 
of previous workers. Foraminiferal faunas from the lower member in the eastern Puente Hills are probably of early Pliocene age (Patsy B. Smith, written communication, 1957). The molluscan assemblage at locality F-6, which is near the top of the member, is indicative, however, of a late Pliocene age on the basis of a twofold division of the Pliocene (J. G. Vedder, written communication, Feb. 20, 1959).

The lower member is well exposed on the ridge south of Tonner Canyon, but the basal part of the unit is not exposed because of faulting. On the north side of the ridge, the lower member is overlain by the La Habra formation of late Pleistocene age. On the south side of the same ridge, the lower member is overlain unconformably by a unit of well-cemented pebbly sandstone marking the base of the upper member of the Fernando formation. The lower member is also exposed farther east in the isolated low hills just west of Olinda and on the long high ridge north of the town of Yorba Linda. In these areas the base of the member is ordinarily either concealed by younger deposits or not exposed because of faulting. The base is well exposed in the northwest quarter of sec. 15, T. 3 S., R. $9 \mathrm{~W}$., where steeply dipping siltstone beds of the lower member overlie a sandstone unit of the Sycamore Canyon member of the Puente formation. North of the town of Yorba Linda, the lower member is overlain by coarse commonly well cemented conglomerate at the base of the upper member. Northeast of Yorba Linda in secs. 23 and 24, T. 3 S., R. 9 W., poorly exposed strata assigned to the lower member of the Fernando formation may belong instead to the Sycamore Canyon member of the Puente formation.

Conditions of deposition

Foraminiferal faunas from the Pliocene rocks in the Los Angeles basin consist almost entirely of species still living off the coast of California. A comparison of fossil and recent foraminiferal faunas indicates that the basin was both deeper and colder at the time the lower part of the Fernando (Repetto of former usage) sediments were being deposited than it was earlier in Tertiary time (Natland and Rothwell, 1954, p. 40). The occurrence of coarse-grained sandstone and conglomerate units in the normally fine grained lower member of the Fernando formation suggests that coarse material from the margins of the basin may have been carried into its deeper parts by turbidity currents (Conrey, 1958).

\section{UPPER MEMBER}

\section{Distribution and character}

The upper member of the Fernando formation is exposed in the eastern Puente Hills area on the ridges east and west of Olinda, where it unconformably over- lies the lower member. In this area the upper member consists mainly of sandstone, pebbly sandstone, and sandy conglomerate. The conglomerate and pebbly sandstone beds at the base of the member are ordinarily well cemented and form bold outcrops. The conglomerate consists of subrounded to well-rounded pebbles and cobbles of hard igneous and metamorphic rocks in a locally well-cemented matrix of coarse to gritty white to yellowish-brown feldspathic sandstone. This is the oldest conglomerate in the map area concontaining pebbles and cobbles of diabase similar to that exposed along the Whittier fault zone just west of the Yorba Linda quadrangle. Sandstone interbedded with the conglomerate is poorly consolidated, silty or fine grained to coarse grained or pebbly, and rarely well bedded; it is commonly cross-stratified and sometimes graded. The sandstone is light gray and weathers to yellowish brown or reddish brown. On the ridges north of Yorba Linda and south of Tonner Canyon, the upper member consists of soft massive reddish-brown and green mudstone, and locally sandy siltstone. The siltstone is light gray to olive gray and micaceous and is well exposed only in fresh excavations.

\section{Thickness}

The thickest exposed section of the upper member of the Fernando formation in the eastern Puente hills is at the western end of the ridge north of Yorba Linda where it is about 1,400 feet thick (pl. 3). The member thins to the east because of erosion prior to deposition of the overlying La Habra formation. The upper member is about 900 feet thick at the eastern end of the East Coyote oil field and in the Richfield oil field.

\section{Foss1ls}

Mollusks from four localities in the upper member in the eastern Puente Hills were identified by J. G. Vedder and are listed below.

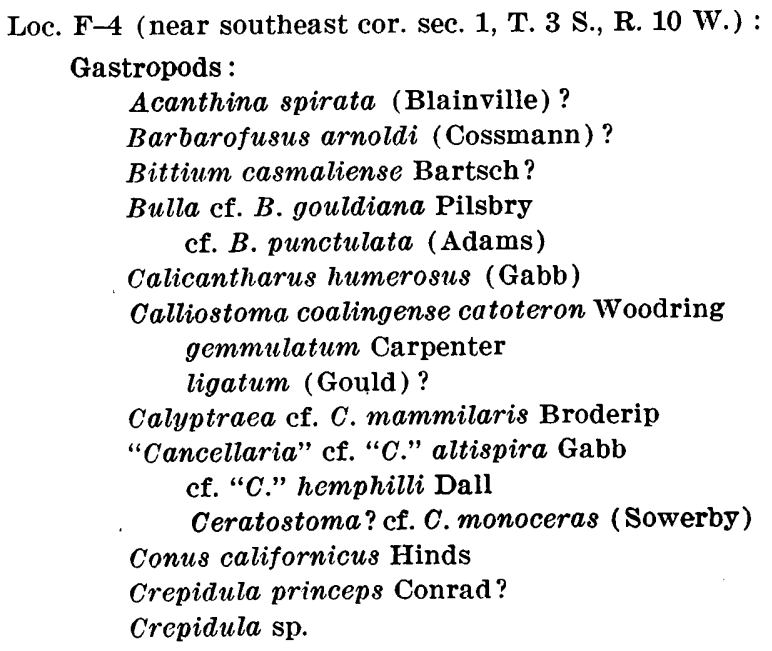


Loc. F-4-Continued

Elaeocyma? cf. E. empyrosia (Dall)

"Gyrineum" elsmerense English

Jaton cf. J. festivus (Hinds)

Kelletia kelletii (Forbes)

Littorina sp.

Mangelia cf. M. variegata Carpenter

Mitrella tuberosa (Carpenter)

Nassarius mendicus (Gould)?

cf. $N$. perpinguis (Hinds)

Neverita reclusiana (Deshayes)

Olivella pedroana (Conrad)?

Ophiodermella incisa (Carpenter)?

Pomaulax gradatus (Grant and Gale)

Pupillaria cf. P. pupilla (Gould)

Tegula cf. T. funebralis (Adams)

Trochita trochiformis (Born)?

Turritella cooperi Carpenter

Scaphopod :

cf. T. gonostoma hemphilli Applin

Dentalium cf. D. neohexagonum Pilsbry and Sharp

Pelecypods :

A.equipecten sp.

Anadara camuloensis (Osmont)

Apolymetis biangulata (Carpenter)

Chione cf. C. fernandoensis English

Cyathodonta cf. C. undulata (Conrad)

Laevicardium cf. L. substriatum (Conrad)

Lucina excavata Carpenter

Lucinisca nuttallii (Conrad)

Lucinoma annulata (Reeve)

Macoma nasuta (Conrad)?

Megapitaria squalida (Sowerby)?

Miltha cf. $M$. xantusi (Dall)

Ostrea vespertina Conrad

Panope generosa (Gould)?

Pecten cf. P. auburyi Arnold

Saccella cf. S. taphria (Dall)

Solen? sp.

Tellina idae Dall?

Trachycardium? sp.

Loc. F-5 (in NE1/4 sec. 16, T. 3 S., R. 9 W.) :

Gastropods :

Aletes? sp.

Bittium casmaliense Bartsch?

Bulla gouldiana Pilsbry?

Calicantharus humerosus (Gabb)

Calliostoma gemmulatum Carpenter

Calyptraea cf. C. mammilaris Broderip

"Cancellaria" hemphilli Dall

Crepidula cf. C. aculeata (Gmelin) sp.

Crucibulum sp.

Diodora ? cf. D. murina (Carpenter)

Fusitrition orcgonensis (Redfield)

Hipponix? sp.

Mangelia sp.

Mitrclla tuberosa (Carpenter)

Nassarius moranianus (Martin) perpinguis (Hinds)?

Neverita reclusiana (Deshayes)?

Ophiodcrmella incisa (Carpenter)?

Pomaulax gradlatus (Grant and Gale)

Scaphander n. sp.?
Loc. F-5-Continued

Seila cf. S. montereyensis Bartsch

Strioterebrum cf. S. martini (English)

Turritella cooperi Carpenter

Pelecypods :

Acila castrensis (Hinds)

Anadara camuloensis (Osmont)

Apolymetis cf. A. biangulata (Carpenter)

Chione cf. C. fernandoensis English

Compsomyax subdiaphana (Carpenter)

Lima n. sp.

Lucina excavata Carpenter

Ostrea vespertina (Conrad)

Patinopecten cf. P. dilleri (Dall)

Pecten auburyi Arnold?

Saccella cf. S. taphria (Dall)

Solen sp.

Trachycardium quadragenarium (Conrad)?

Scaphopod :

Dentalium sp.

Loc. F-7 (in NE1/4 sec. 7, T. 3 S., R $9 \mathrm{~W}$; in basal conglomerate of upper member of Fernando formation):

Pelecypod :

Ostrea erici Hertlein

Loc. F-8 (in NE1/4 sec. 7, T. 3 S., R. 9 W.; in basal conglomerate of upper member of Fernando formation):

Gastropods :

Aletes? sp.

Calliostoma cf. C. gemmulatum Carpenter

Pelecypods :

Chlamys hastatus (Sowerby)

cf. C. rubidus (Hinds) =?C. hindsii (Carpenter)

Lima n. sp.?

Ostrea erici Hertlein vespertina Conrad

Pecten stearnsii Dall?

Barnacle :

Balanus sp.

Age and stratigraphic relations

In the eastern Puente Hills, the upper member of the Fernando formation unconformably overlies beds of probable early Pliocene age assigned to the lower member of the Fernando formation and underlies strata of the La Habra formation of late Pleistocene age. The upper member is considered to be of late Pliocene age in the eastern Puente Hills area and is probably equivalent in this area to the Pico formation of previous workers. J. W. Durham $(1954$, p. 24) correlated the Pico formation of the Los Angeles basin with the San Diego formation of the San Diego area and with the upper part of the Pico formation at its type area in the Ventura basin. These units are assigned by J. W. Durham to the Etchegoin (middle Pliocene) and San Joaquin (upper Pliocene) megafaunal stages of the standard Pacific Coast section.

The upper and lower members of the Fernando formation are separated by an unconformity on the ridge west of Olinda and south of Tonner Canyon. North of the town of Yorba Linda, the two members are apparently conformable. The base of the upper member is 
usually marked by well-cemented pebbly sandstone and conglomerate beds that form bold outcrops.

On the ridge south of Tonner Canyon, the upper member is overlain unconformably by the continental La Habra formation of late Pleistocene age. The upper member thins to the east because of erosion prior to deposition of the La Habra formation.

\section{QUATERNARY SYSTEM}

\section{PLEISTOCENE SERTES}

UNNAMED STRATA OF PLEISTOCENE AGE

A sequence of marine and nonmarine strata of Pleistocene age overlies the Fernando formation in the subsurface in the southwestern part of the Yorba Linda quadrangle. The upper part of this unit is exposed in the Coyote Hills west of the map area, where it is about 715 feet thick. In an exposed section 1.5 miles northwest of the southwest corner of the map area, the Pleistocene series consists of about 50 feet (base not exposed) of massive light-yellowish-gray silty sandstone that contains much biotite, sporadic thin lenses of well-rounded pebbles, and a well-cemented concretionary horizon that contains marine mollusks of probable early Pleistocene age. The marine sandstone is about 450 feet thick in nearby wells and is unconformably overlain by about 220 feet of massive dark- to light-reddish-brown and yellow-brown pebbly sandstone and sandy conglomerate that contains interbedded 1-inch layers of coarse to gritty light-colored sandstone. The sandstone has a clayey and earthy matrix and a nonmarine aspect. This relatively resistant pebbly sandstone and conglomerate unit is overlain by about 495 feet of interbedded olive-gray marly mudstone that locally contains plant fragments and ostracods; and light-brownish-gray and pinkish-gray massive coarsegrained to gritty earthy sandstone with beds and stringers of well-rounded pebbles of red volcanic and light-colored plutonic rocks.

This sequence of nonmarine rocks includes the lower half of Dudley's (1943, p. 350-351) lower Pleistocene section, and is unconformably overlain by the upper Pleistocene La Habra formation in the Coyote Hills.

The northeastern boundary of this lower Pleistocene marine and postlower Pleistocene nonmarine sequence is not precisely known. The lower part of the sequence is known from well cores in the southwest part of the Yorba Linda quadrangle, where it is termed unnamed strata of Pleistocene age.

\section{LA HABRA FORMATION}

Nonmarine sandstone and silty conglomerate beds exposed along the southern margin of the Puente Hills were included in the Fernando formation by
English (1926). They were later called La Habra conglomerate by Eckis (1934, p. 49), who adopted a name proposed for the unit by $\mathbf{H}$. M. Bergen in an unpublished report. Eckis considered the unit to be of late Pliocene or early Pleistocene age. The La Habra formation was redefined by Durham and Yerkes (1959), who assigned to it a late Pleistocene age based on its stratigraphic relations in the La Habra-Yorba Linda area where it was first recognized by Bergen.

\section{Distribution and character}

The La Habra formation is well exposed near the western border of the Yorba Linda quadrangle, where the lower part of the unit is from 500 to 600 feet thick. A similar sequence of beds nearly 1,000 feet thick is exposed north of the town of Yorba Linda. The formation is covered by alluvial deposits in most of the southwestern part of the Yorba Linda quadrangle (pl. 3). A section of the formation follows.

Section of the La Habra formation measured in roadcuts high on the eastern side of a small canyon in the NW1/4 sec. $7, T$. s S., R. $9 \mathrm{~W}$., Yorba Linda quadrangle

Top not exposed.

12. Sandstone, reddish-brown, fine- to medium-grained, massive, earthy ; with interbedded siltstone------

11. Sandy conglomerate and pebbly sandstone, lightgreenish-gray to buff; contains angular to subrounded pebbles and cobbles of granitic rocks as large as 7 in. but averaging 1 in. in size; and many $1 / 2$ - to 4-in. chips and slabs of limy white siltstone; bedding chaotic, sorting poor; matrix of light brown, coarse-grained, poorly sorted, earthy conglomeratic sand, poorly consolidated with calcareous cement

10. Sandstone, tan to reddish-gray, massive, earthy; with interbedded limy, mudstone showing hackly fracture; bedding fair

9. Pebbly sandstone and sandy conglomerate similar to unit 11, but somewhat better bedded in upper part, poorly sorted below ; contains cobbles as large as 6 in., but averaging 1 in. in size

8. Sandstone, light-tan to reddish-brown, massive to thick-bedded, earthy ; with stringers of pebbles and white siltstone chips

7. Sandy siltstone, light-pinkish gray, well-bedded hackly fracture, somewhat marly__._.

6. Sandstone, light pinkish-gray, weathering light brown, coarse-grained, poorly sorted, massive, earthy and clayey; with thin stringers of pebbles and small white siltstone chips; bedding better in upper than in lower part.

5. Pebbly sandstone and sandy conglomerate as in units 11 and 9 ; with boulders as large as 14 in. in size, long axes of larger clasts arranged subparal-

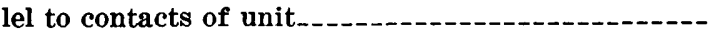

4. Sandstone, light-brown, fine-grained, well-sorted, soft and friable, hackly fracture...-.

3. Pebbly sandstone and sandy conglomerate similar to unit 1 
2. Mudstone and siltstone, poorly exposed, soft, grayish-green to reddish-brown, sandy; has topographic expression as valleys and swales_____-_ 105

1. Conglomerate (see fig. 12), pebbly sandstone, and sandy conglomerate, light grayish green to lightbrown; has angular to subrounded pebbles and cobbles of granitic rock as large as 5 in. and averaging $1 \mathrm{in}$. in diameter, and abundant chips and slabs of buff to white limy siltstone; bedding chaotic, sorting poor; matrix of earthy and clayey sand. Lower contact is well defined by a slight angular unconformity with some channeling of underlying reddish-brown and green mudstone_.-- 8

Total $211 \pm$

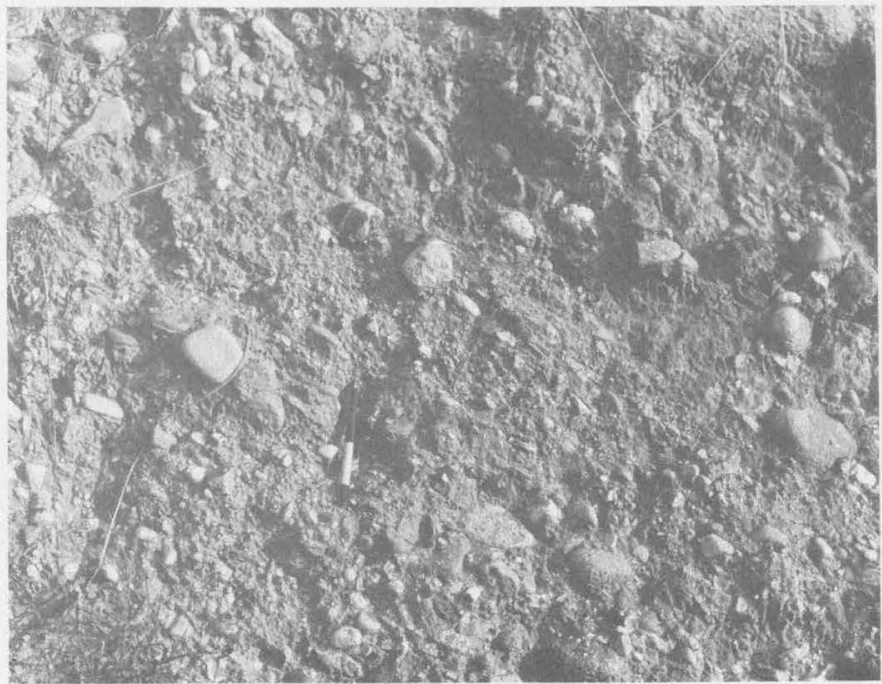

Figure 12.-Basal conglomerate of the La Habra formation exposed in a roadcut in the Brea-Olinda oil field south of Tonner Canyon. The tabular fragments and pebbles are hard white siltstone derived from the Puente formation.

North of the town of Yorba Linda, the base of the La Habra formation is marked by a unit of white pebbly sandstone 100 to 150 feet thick. This sandstone is white, coarse to gritty, poorly sorted, clayey, semiconsolidated, and conspicuously cross-stratified. It contains well-rounded pebbles as large as 3 inches, but more commonly $1 / 2$ to 1 inch in size. The pebbles occur both as scattered clasts and as lenses and stringers as much as 6 feet thick. The basal sandstone is overlain by a unit 25 to 50 feet thick consisting of dense reddish-brown claystone containing scattered sand grains. Overlying the claystone unit is a unit of poorly bedded grayish-brown poorly sorted sandy conglomerate with a silty matrix. This sandy conglomerate is overlain in turn by beds of reddish-brown, silty sandstone and greenish-clay clayey calcareous mudstone and siltstone, similar to those in the upper part of the formation in other areas. White caliche beds occur in exposures of the calcareous greenish-gray and red- brown mudstone beds. Near the north edge of section 22 , T. 3 S., R. 9 W., the upper part of the formation is cut by channels filled with gray sandy gravel similar to Recent alluvial gravel in the area.

\section{Thickness}

The La Habra formation is as much as 1,000 feet thick in the area north of the town of Yorba Linda. It is only 500 to 600 feet thick near the western edge of the Yorba Linda quadrangle and about 400 feet thick on the southern flank of the East Coyote oil field. It is probably about 1,500 feet thick north of the East Coyote oil field (pl. 3). South of the Coyote Hills uplift the La Habra formation may attain thicknesses of 2,500 feet or more.

\section{Age and stratigraphic relations}

The La Habra formation is unfossiliferous, but it unconformably overlies strata ranging in age from early Pliocene to postearly Pleistocene. The regional unconformity at the base of the formation probably reflects the middle Pleistocene deformation of the Los Angeles basin area. Beds of the La Habra formation are tilted to high angles and are locally overturned near the Whittier fault; the beds are overlain by flatlying alluvial deposits of late Pleistocene or Recent age.

In the Coyote Hills west of the Yorba Linda quadrangle, the La Habra formation unconformably overlies marine and nonmarine strata of early and postearly Pleistocene age. At the west edge of the quadrangle, near the south margin of the hills, the formation overlies siltstone beds in the upper member of the Fernando formation, and about 1 mile to the east, it overlies beds about 750 feet stratigraphically lower in the same member. On the ridge south of Tonner Canyon, the formation unconformably overlies the lower member of the Fernando formation (pl, 3). The stratigraphic relations of the formation suggest that it is most probably of late Pleistocene age.

\section{Conditions of deposition}

The La Habra formation consists of nonmarine sedimentary rocks derived largely from the nearby Puente Hills; however, strata in the basal part of the formation were derived from different sources. Northwest of Carbon Canyon, the basal unit of the formation consists of silty coarse unsorted conglomerate containing both angular pebbles and cobbles and abundant white siltstone debris derived from the Puente formation. Southeast of Carbon Canyon Creek, the basal part of the formation includes cross-stratified clayey white sandstone containing small well-rounded pebbles unlike any possible nearby source rock. This sandstone is well exposed in a large gravel pit in the northwest corner of sec. 35, T. 3 S., R. 9 W., just 
south of the Yorba Linda quadrangle. The clasts in the basal beds of the La Habra formation in the area northwest of Carbon Canyon Creek were derived from adjacent parts of the Puente Hills, and those in the area to the southeast were probably brought from a more distant source by the Santa Ana River. The upper part of the formation consisting of silty sandstone and siltstone is lithologically uniform throughout the eastern Puente Hills, this uniformity suggests a common source for the sediments-namely, the Puente formation in the nearby Puente Hills.

\section{PLEISTOCENE TO RECENT SERIES}

Alluvial deposits of late Pleistocene, Recent (?) and Recent age occurring in the eastern Puente Hills area are classified as either older alluvium or younger alluvium. Older alluvium is semiconsolidated material deposited in and around the hills and dissected by the present streams. Along the Santa Ana River, it includes alluvial terrace deposits. Younger alluvium is uncolsolidated material that is being, or has lately been, transported by streams.

\section{OLDER ALIUVIUM}

\section{Distribution and character}

The sediments of late Pleistocene and Recent(?) age that border the eastern Puente Hills are alluvial fan and terrace deposits. The alluvial fan deposits were built by streams coming from the neighboring highlands and have been accumulating since at least the time of the middle Pleistocene deformation of the Los Angeles basin area, when an increase in the elevation of some areas provided a source for coarser deposits. The alluvial fan deposits overlie older strata unconformably near the margins of their basins of accumulation, but they are probably conformable on older strata nearer the centers of these basins.

The alluvial fan deposits in valleys bordering the eastern Puente Hills consist chiefly of poorly sorted silt, sand, and gravel. They are cut by the present streams and have a soil profile developed on their surface. The resulting soils are chiefly silty loam, sandy loam, sandy adobe, and adobe (Nelson and others, 1917). In the area between Yorba Linda and La Habra, the older alluvium has been dissected to such an extent that the original surface of the deposit has been nearly or entirely destroyed.

Alluvial terrace deposits occur along the Santa Ana River and some of its larger tributaries. They consist chiefly of sand and gravel and have better bedding than do the locally derived and poorly sorted alluvial fan deposits with which they merge in the area south of Yorba Linda.
An old high-level alluvial terrace deposit about 100 feet thick and from 245 to 595 feet above stream level is exposed north of the Horseshoe Bend of the Santa Ana River. At its base is a well-cemented unit 25 or 30 feet thick consisting of coarse gravel in an abundant matrix of sand and silt. Above the basal unit is a sequence of sand beds overlain by reddish-brown massive silt. This deposit, which lies nearly flat, rests with marked angular unconformity on rocks of the Topanga and Puente formations and is cut on the northeast side by the Whittier fault (fig. 13). Other alluvial terrace deposits north of the Santa Ana River near Horseshoe Bend consist chiefly of massive reddishbrown earthy silt containing lenses and stringers of sand and gravel. The silt has an abundance of white caliche in fractures, on bedding planes, and in discrete layers as much as 3 or 4 inches thick. The sand is fine to coarse grained, generally light gray, cross-stratified, and commonly pebbly. The gravel consists mainly of pebbles and small cobbles, but some boulders also occur. The upper 2 to 3 feet of these deposits usually consists of silty material; sand and gravel are more common near the base.

The older alluvium in the eastern part of the Prado Dam quadrangle was considered by Eckis (1934, p. 193) to be fan deposits, derived chiefly from the Santa Ana Mountains and later beheaded by the Santa Ana River.

\section{Thicknoss}

Deposits of older alluvium are probably 500 feet or more thick near the northeast corner of the Prado Dam quadrangle. The Southern Counties Petroleum and Drilling Corp. well 1 (pl. 1, well 192; sec. 22, T. 2 S., R. 8 W.), drilled near Los Serranos, penetrated tree logs buried at a depth of 380 feet in alluvial material. A maximum thickness of at least 1,400 feet is given by Eckis $(1934$, p. 58) for the older alluvial deposits in the deeper part of the San Bernardino Valley, northeast of the eastern Puente Hills.

The alluvial terrace deposits along the Santa Ana River are as much as 100 feet thick. Another thick accumulation of older alluvial material occurs in the La Habra syncline between the Puente Hills and the Coyote Hills uplift.

\section{Age}

Most of the older alluvium exposed in the map area is probably late Pleistocene in age; the upper parts of some deposits may be Recent in age. Probably the oldest alluvial deposits in the eastern Puente Hills are those just north of Horseshoe Bend. Their base is as much as $\mathbf{5 9 5}$ feet above the Santa Ana River, and although they lie nearly flat, they have been cut 
by the Whittier fault. Other alluvial deposits along the Santa Ana River have their base as much as 250 feet above the river and apparently are not cut by faults. The alluvial terrace deposits along the Santa Ana River are equivalent in age to part of the alluvial fan deposits south of Yorba Linda.

\section{YOUNGER ALIUVIUM}

The younger alluvium occurs in the bed of the Santa Ana River and in the bottoms of the canyons in the eastern Puente Hills. It consists of poorly sorted silt, sand, and gravel. Near the surface the alluvium is generally of sand or silt size, but lenses or beds of pebbles, cobbles, or even boulders occur below the surface. The coarser material is carried by the streams during times of heavy runoff and is buried by finer material deposited as the rate of flow slackens. The younger alluvium is distinguished by its position in canyon bottoms, its lack of consolidation, and its fresh, unweathered appearance.

\section{STRUCTURE}

\section{STRUCTURAL SETTING}

The Puente Hills are northeast of the deep central part of the Los Angeles basin. They are a structural unit that has been uplifted between the Whittier fault zone, which is near the southwestern margin of the hills, and the Chino fault zone, which is near the northeastern margin. The narrow troughlike Chino basin is northeast of the eastern Puente Hills, and a structurally high platform of granitic basement rocks covered by a relatively thin veneer of sedimentary rocks is present northeast of the Chino basin. The La Habra syncline, which is south of and nearly parallel to the southern edge of the Puente Hills, lies between the hills and the Coyote Hills uplift to the south.

Structure sections across the eastern Puente Hills area are shown in plates 3 and 4.

\section{WHITTIER FAULT ZONE}

Between the Santa Ana River and the Horseshoe Bend fault, the trace of the Whittier fault separates strata of the Vaqueros and Sespe formations and Topanga formation exposed on the south side from strata of the Puente formation exposed on the north side. In this part of the map area, the Whittier fault appears to be a single fault rather than a zone of two or more major faults. The fault trace is concealed by deposits of older alluvium near the Santa Ana River (fig. 13).

Northwest of Horseshoe Bend, the Whittier fault generally comprises a zone of two or more major faults separating strata of the Puente formation on the north side from younger strata of the Puente and Fer- nando formations on the south side. At the eastern border of the Yorba Linda quadrangle, the zone includes three poorly exposed subparallel faults that separate slices of contorted siltstone and sandstone of the Puente formation. Strata of early Pliocene age occur immediately south of the southernmost fault. The best exposures of the faults between Horseshoe Bend and Carbon Canyon are in the area north of Telegraph Canyon, where the north trace separates sandstone of the Soquel member on the north from siltstone of the La Vida member on the south (fig. 14).

Between Carbon Canyon and Tonner Canyon the Whittier fault zone includes two faults that bound a slice of steeply dipping beds of the Sycamore Canyon member. (pl. 4). South-dipping beds of the Sycamore Canyon member are exposed south of the fault slice, and steeply northward dipping beds of the La Vida and Soquel members are exopsed north of it. An excellent exposure of the trace of the northern fault is in a cut west of the center of sec. 9, T. 3 S., R. 9 W., where steeply dipping sandstone beds of the Soquel member are thrust over siltstone of the Sycamore Canyon member and the fault plane dips $37^{\circ} \mathrm{NE}$.

Between Tonner and Brea Canyons, the Whittier fault zone includes three principal faults (fig. 14). The northern fault is well exposed on the west wall of Tonner Canyon, where overturned beds of the Soquel member are in fault contact with siltstone of the La Vida member to the north. All three faults dip $70^{\circ}$ to $80^{\circ} \mathrm{N}$. (pls. 3 and 4 ).

Along the line of structure section $A-A^{\prime}$ (pl. 3), the stratigraphic separation across the Whittier fault zone is about 10,500 feet. Three miles to the southeast along the line of structure section $D-D^{\prime}$ (pl. 3), it is about 7,000 feet. Near the west edge of the Prado Dam quadrangle, stratigraphic separation of strata of late Miocene age across the fault zone may be only about 2,000 feet (pl. 4). Southeast of the Horseshoe Bend fault, the stratigraphic separation across the Whittier fault is about 4,000 feet and opposite in sense to that northwest of Horseshoe Bend (pl. 4).

The courses of the larger south-flowing streams in the eastern Puente Hills turn westeward for as much as 8,800 feet where they cross the Whittier fault zone, before they resume a southerly direction. These westerly offsets in the stream courses have been interpreted as due to differential erosion of softer rock along the Whittier fault zone (English, 1926, p. 65), and as the result of lateral movement along the Whittier fault (Hill, 1954, p. 10). The latter interpretation is supported by the fact that the offsets are all in the direction that would result from right-lateral movement along the Whittier fault. 


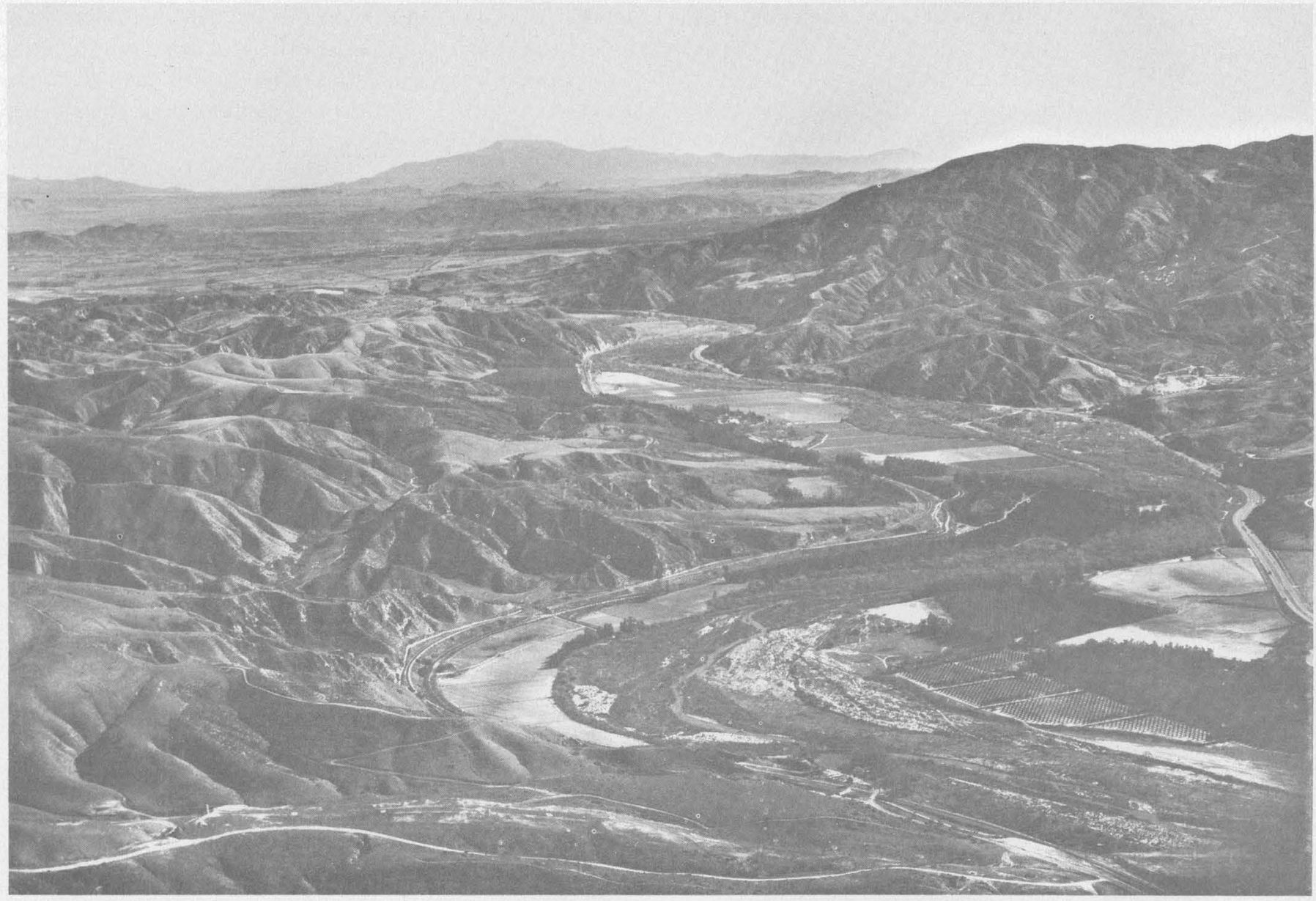

Figure 13.-Aerial view southeastward along the Whittier fault zone southeast of the Horseshoe Bend of the Santa Ana River. The fault zone trends obliquely from lower left toward the center of the photograph. Old alluvial terrace deposits at lower left are cut by the fault; younger alluvial terrace deposits are undisturbed.

The possible existence of the Whittier fault in premiddle Miocene time is suggested by the presence of at least 1,275 feet of premiddle Miocene strata south of the fault zone in the Richfield oil field, whereas strata older than middle Miocene in age are absent north of the fault zone in the Brea-Olinda oil field. The Whittier fault may be as old as late Miocene in age, for the diabase intrusive rocks of early late Miocene age that are associated with it were probably intruded along the fault. At least some of the movement on the fault occurred in Pleistocene, and probably late in Pleistocene time, for strata of the La Habra formation of late Pleistocene age are steeply tilted and locally overturned near the fault zone. Elevated deposits of older alluvium are cut by the fault near Horseshoe Bend, but lower level deposits of older alluvium in the same area apparently are not affected by the fault (fig. 13).

\section{CHINO FAULT}

The Chino fault trends N. $38^{\circ} \mathrm{W}$. near the northeastern margin of the eastern Puente Hills and dips steeply southwestward. The fault is covered by alluvial deposits southeast and northwest of its exposure in the eastern Puente Hills. The displacement on the fault probably increases toward the southeast. The trace of the fault is usually poorly exposed and is characteristically marked by a zone of contorted and crumpled siltstone on the southwest side that has been crushed against more resistant pebbly sandstone and conglomerate on the northeast side.

The best exposure of the Chino fault is in the cuts made for State Route 71 at the easternmost tip of the hills (fig. 15). The fault trace in the roadcut is a single distinct line, but siltstone on the southwest, upthrown side of the fault is crumpled and shattered in a zone about 50 feet wide, and the general attitude of the bedding is obscure. The fault strikes N. $50^{\circ} \mathrm{W}$. between cuts on opposite sides of the highway, and it dips about $60^{\circ} \mathrm{SW}$. The strata northeast of the fault are silty fine-grained sand, sandstone, pebbly sandstone, and conglomerate, in all of which bedding is well 


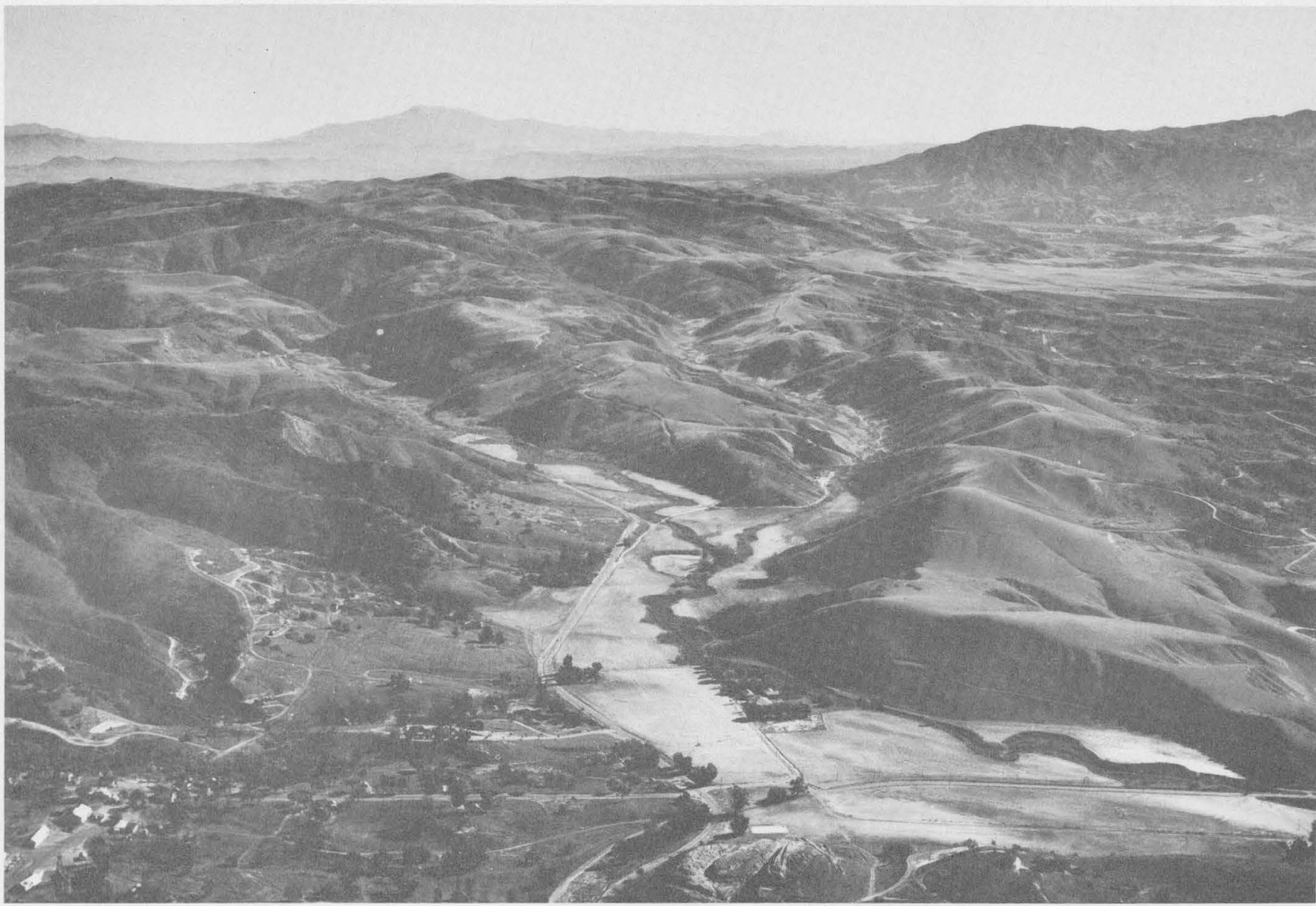

Figure 14,-Aerial view southeastward along the Whittier fault zone southeast of Carbon Canyon. The fault zone trends from lower left to upper right. The eastern end of the Brea-Olinda oil field is in the foreground and the junction of Carbon and Telegraph Canyons is in the center.

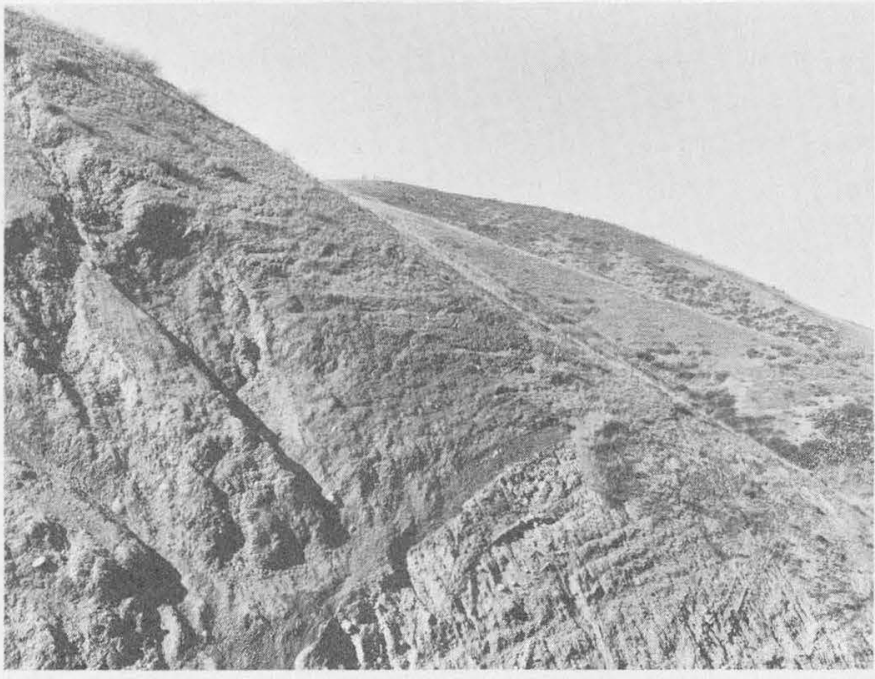

Figure 15.-Exposure of the Chino Fault in a roadeut 1.3 miles north of Prado Dam. The fault strikes N. $50^{\circ}$ W. and dips $65^{\circ} \mathrm{SW}$. Siltstone of the Sycamore Canyon member of the Puente formation on the left is thrust over younger, coarser grained strata of the same member on the right. preserved. Strata on both sides of the fault dip steeply southwest and roughly parallel to the fault plane. Information from seven wells that penetrate the fault (pl. 1, wells $7,54,92,113,114,152,153$ ) indicates that the fault maintains a dip of $59^{\circ}$ to $67^{\circ}$ to a depth of at least 2,575 feet below sea level. The fault may be steeper in areas to the northwest.

A narrow band of steeply dipping and overturned pebbly sandstone and conglomerate beds exposed just northeast of the Chino fault may represent a series of en echelon drag folds associated with the fault. These folds are exposed in cuts along State Highway 71, 0.1 mile north of the trace of the Chino fault. The axes of the folds plunge about $72^{\circ} \mathrm{SE}$., suggesting a component of lateral movement along the fault.

The stratigraphic separation across the Chino fault in the central part of its exposure is about 1,200 feet (pls. 3 and 4). The stratigraphic separation across the fault at the southeastern end of its exposure is about. 2,400 feet (pl. 4). 
The youngest strata cut by the Chino fault are assigned to the Sycamore Canyon member of the Puente formation of late Miocene age, although the uppermost part of this unit may include strata of Pliocene age. Alluvial deposits are not disturbed by the fault. Movement along the Chino fault probably followed formaof the Mahala anticline and probably coincided with or followed the middle Pleistocene deformation of the Los Angeles basin.

STRUCTURAL FEATURES NORTH OF THE WHITTIER FAULT ZONE AND WEST OF THE CHINO FAULT FAULTS

The faults occurring between the Whittier and Chino faults can be placed in three groups. One group consists of east- and northeast-trending faults that branch from the Whittier fault zone. Included in this group are several large faults in the southeastern quarter of the Yorba Linda quadrangle, and the Bryant and Scully Hill faults in the Prado Dam quadrangle. Most of these faults dip northward (pl. 4), and some are cut by the Aliso Canyon fault.

A second group of east-trending faults occurs in the northern part of the map area. This group includes the Diamond Bar fault, Arnold Ranch fault, and the east-trending fault just north of the Chino Soquel oil field. The Arnold Ranch fault forms the south side of an upthrown block from which the La Vida member of the Puente formation was nearly removed by erosion prior to deposition of the Soquel member; this condition indicates that the fault was active during late Miocene time. Both the Arnold Ranch fault and the east-trending fault north of the Chino-Soquel oil field extend into basement rock.

A third group of faults bound the structural block containing the Arena Blanca syncline. This structural block has moved relatively northward along reverse faults that form its northern edge and along the Aliso Canyon fault, which is a tear fault at its southeastern edge. The resulting compression at the south end of the Ridge syncline has caused a broadening of the syncline there and development of a subsidiary westtrending syncline on its west side. Faults of this group are as young as, or younger than, any of the other faults in the map area.

\section{Fords}

Seven principal anticlines, the Arena Blanca, Bryant Ranch, Carbon Canyon, Diamond Bar, Mahala, Soquel Canyon, and Telegraph Canyon, are exposed in the eastern Puente Hills north of the Whittier fault zone and west of the Chino fault. The most important in the production of oil is the Mahala anticline at the Mahala oil field. This anticline is an asymmetric fold that parallels the Chino fault and is about 3 miles long. The Chino fault cuts the anticline and forms closure on the northeast side (pl.4).

Oil is also produced from the Soquel Canyon anticline at the Chino-Soquel oil field. The anticline plunges northeast, and closure is formed by southeasttrending faults that cut the axis to the southwest.

The Arena Blanca anticline is at the northern edge of the structural block that contains the Arena Blanca syncline. The east-trending folds in this block are the result of its compression as it moved relatively northward against the Ridge syncline. The Arena Blanca anticline is not considered to be the offset nose of the Bryant Ranch anticline.

The Carbon Canyon anticline is exposed in the northwest corner of the Prado Dam quadrangle, where it plunges about $30^{\circ}$ E. An anticline exposed near the head of Carbon Canyon in the Yorba Linda quadrangle may be the offset southwestern continuation of the Carbon Canyon anticline.

Only two large synclines are exposed north of the Whittier fault zone and west of the Chino fault. The south-trending Ridge syncline ends abruptly against the structural block that contains the east-trending Arena Blanca syncline. The Ridge syncline broadens at its southern end and has a subsidiary west-trending fold there on its west flank, indicating compression due to relative northward movement of the structural block containing the Arena Blanca syncline. The easttrending orientation of the Arena Blanca syncline and associated anticline are probably due to this same northward compression.

The age of the folds north of the Whittier fault zone is not determined exactly, but strata as young as latest Miocene are involved in folding there. The folds are all cut by faults considered to be related to movement along the Whittier fault zone, but the last movement along that zone probably occurred during or after late Pleistocene time.

\section{STRUCTURAI FEATURES NORTHEAST OF THE EASTERN PUENTE HILIS}

The Chino basin was named and described by Woodford and others (1944) as a narrow structural trough 1 or 2 miles wide, bounded on the southwest by the Chino fault and on the northeast by an unnamed fault or faults. The western edge of the basin is near the margin of the eastern Puente Hills; the eastern edge trends about $\mathrm{N} .25^{\circ} \mathrm{W}$. and is about 0.6 mile northeast of South Central Avenue. Toward the southeast; the eastern edge of the basin apparently parallels the Chino fault and is about 1 mile northeast of the projected trace of the fault. The basin may be the northwesterly extension of the Elsinore structural trough. 
In the Chino basin, granitic basement rocks are at depths of 5,000 feet or more below sea level and are overlain by strata of middle Miocene age or older. Northeast of the Chino basin in the Prado dam quadrangle, granitic basement rocks occur at depths between 1,000 and 2,000 feet below sea level and are overlain by rocks of late Miocene age. This structurally high area northeast of the Chino fault is the western part of a larger structural unit called the Parris block by English (1926, p. 54).

\section{STRUCTURAL FEATURES SOUTH OF THE EASTERN PUENTE HILLS}

The La Habra syncline is a long, narrow, asymmetrical northwest-trending and -plunging structural feature in the area just south of the Puente Hills, between the towns of Yorba Linda and Whittier. Its axis is about 1.5 miles southwest of and parallel to the Whittier fault zone. The north limb of the syncline is bounded by the Whittier fault zone and dips more steeply than does the south limb.

The Coyote Hills uplift trends about N. $72^{\circ} \mathrm{W}$. and lies south of and parallel to the La Habra syncline. The West Coyote and East Coyote oil fields are on separate east-trending anticlines on the Coyote Hills uplift and arranged en echelon along it. Strata of the La Habra formation of late Pleistocene age are folded at the East Coyote oil field (pl. 3).

Most of the faults exposed in the map area south of the Whittier fault zone are steeply dipping, trend approximately parallel to the Whittier fault, and are probably related to it. Near the Whittier fault zone, the stratigraphic separation across the related faults is commonly several thousand feet, and in a reverse sense. Most of these faults cut strata of Pliocene age and apparently do not affect Quaternary terrace deposits.

The Horseshoe Bend fault in the southwest corner of the Prado Dam quadrangle dips about $55^{\circ} \mathrm{W}$. (pl. 4). Stratigraphic separation of beds across the fault is about 4,000 feet. The Horseshoe Bend fault marks the northwesternmost exposure of relatively old rocks that belong to the Santa Ana Mountains structural block.

\section{PHYSIOGRAPHY EASTERN PUENTE HILLS}

The topography of the eastern Puente Hills reflects their complicated Quaternary history of uplift, erosion, stream capture and change of base level. Remnants of an old relatively flat erosional surface are preserved in the higher parts of the hills. This surface truncates complicated geologic structural features and was crossed by a few streams that flowed into the area from the great fans in the San Bernardino Valley to the northeast. Some of the present streams, such as those in Brea and Tonner Canyons, flow in comparatively narrow and steep-sided canyons cut in broader valleys that were occupied by ancient streams at the time the old erosion surface was formed. Following development of the old erosion surface the Puente Hills area was elevated relative to the area on the south, but probably it was elevated without pronounced tilting. Some of the through-flowing streams maintained themselves across the uplifted area and formed antecedent valleys with walls having slopes that in cross profile are convex upward (fig. 16). Following a regional lowering of baselevel that affected the major streams in the area, Brea and Tonner Canyons were beheaded by diversion upstream on the fan surfaces in the San Bernardino Valley. The most recent episode in the erosional history of the area is marked by the entrenchment of streams into the broader valley bottoms. This entrenchment is especially striking in Brea Canyon just north of the Whittier fault, where the stream has cut a narrow steep-walled gully about 30 feet into alluvial deposits and bedrock (fig. 16). The depth of the gully decreases in the upstream direction, and headward erosion of the gully has not progressed beyond about the center of sec. 29 , T. 2 S., R. $9 \mathrm{~W}$. The gross drainage pattern in the eastern Puente Hills is asymmetrical in that streams flowing southwest are much longer than those draining north or northeast. This asymmetry suggests some northeasterly tilting of the Puente Hills during at least the later stages of their uplift.

\section{SANTA ANA RIVER}

The Santa Ana River has its headwaters in the San Bernardino Mountains, crosses the broad alluviated San Bernardino Valley, flows between the Puente Hills and the Santa Ana Mountains in a steep-sided and relatively narrow canyon, and crosses the southeastern part of the Los Angeles plain to reach the sea. As the river approaches the eastern Puente Hills, it flows on a narrow flood plain between banks 20 to 30 feet high that are cut into deposits of older alluvium. North of the river the dissected surface of the older alluvial deposits in the eastern part of the Prado Dam quadrangle slopes northward and is buried beneath the south-sloping alluvial fans that extend southward from the San Gabriel Mountains. North of Prado Dam the bed of the river is as much as 25 feet below the surface of the older alluvium. Chino Creek and the lesser streams that drain from the north have also cut into the older alluvium, and more recently they have incised their own valley bottoms in order to be at grade with the Santa Ana River. The depth to 


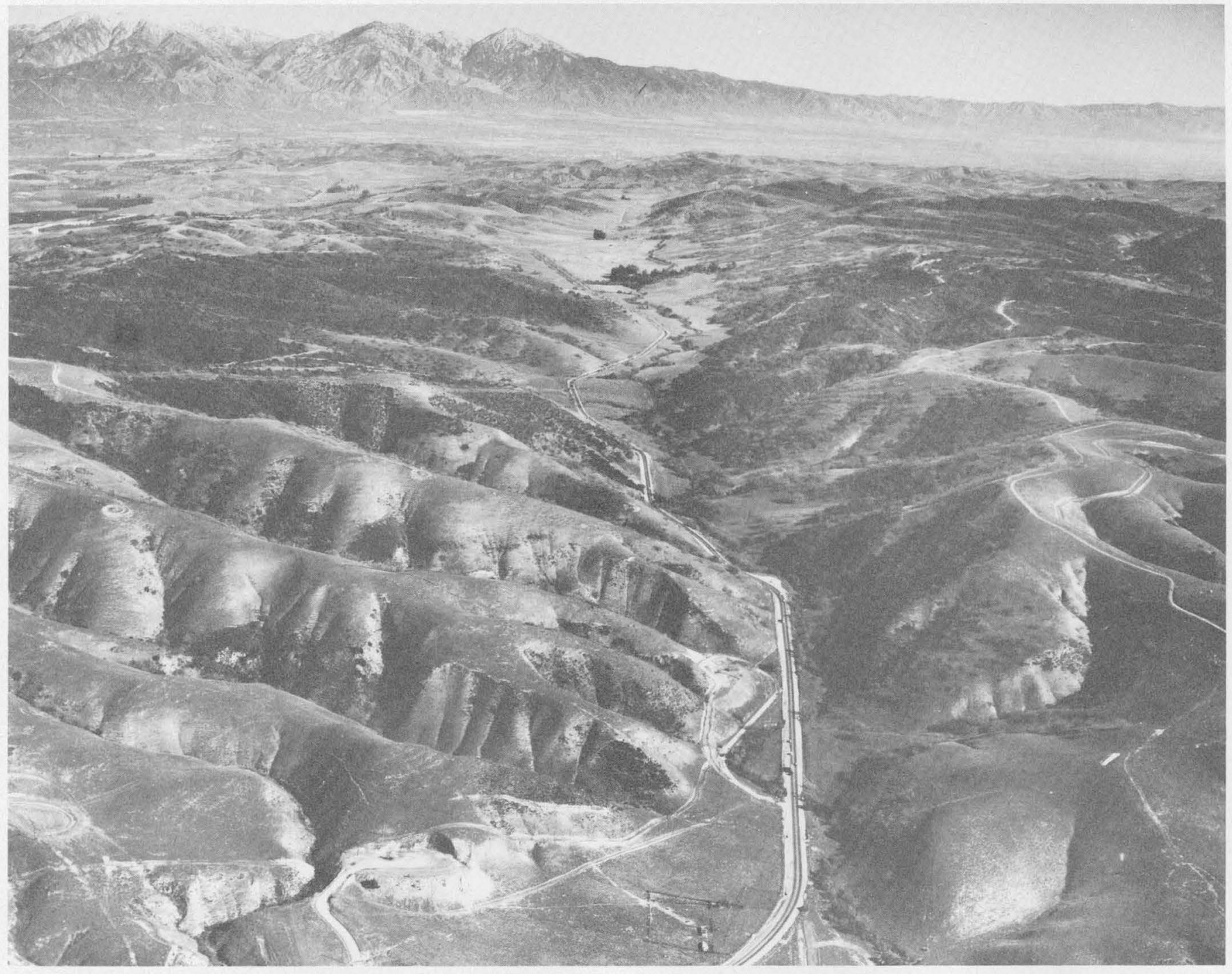

Figure 16.-Aerial view northeastward up Brea Canyon from over the Whittier fault zone. The bare slopes in the foreground are underlain by siltstone of the La Vida member of the Puente formation. The brush-covered slopes in the center and background are underlain by sandstone of the Soquel member. The higher parts of the hills are remnants of an old erosion surface. The stream is entrenched as much as 30 feet into the alluvial deposits that floored ancient Brea Canyon. The canyon walls have slopes that are convex upward.

which these tributary streams cut the older alluvium decreases away from the Santa Ana River.

Small alluvial cones have been built on the surface of the older alluvium bordering Chino Creek by streams that issue from the hills north of Prado Dam. These cones and the older alluvium in the canyons behind them are incised by intermittent streams.

The course of the Santa Ana River through its canyon between the eastern Puente Hills and the Santa Ana Mountains is generally considered to antecede the uplift of those areas (Sharp, 1954, p. 9). The canyon is about 9 miles long and only 0.3 mile wide at the narrowest place, just below Prado Dam. The alluvial fill in the canyon has a nearly uniform thickness of from 80 feet near the upper end to 100 feet in the lower part. The alluvial deposits are coarsest at depth, where boulders 1 to 2 feet in diameter are present, but the deposits are predominantly sandy near the surface (Post, 1928, p. 261-264). The bedrock floor beneath the alluvium of the river bed is deeper both above the head of the canyon and below its mouth (Eckis, 1934, p. 28). Remnants of alluvial material deposited by the Santa Ana River at elevations now above the river bed are present on both sides of Santa Ana Canyon.

\section{AREA SOUTH OF THE PUENTE HILLS}

The Coyote Hills uplift is south of, and trends nearly parallel to, the Whittier fault zone. The Santa Fe Springs, West Coyote, and East Coyote oil fields are 
on a series of generally east-trending anticlines arranged en echelon along the uplift. The topographic expression of the anticline at the West Coyote oil field is good, but that of the anticline at the East Coyote oil field is poor and noticeable only in the area west of the Yorba Linda quadrangle. The structural features at the Richfield oil field have little topographic expression.

During most of late Quaternary time, alluvial material accumulated between the Coyote Hills uplift and the Puente Hills, while a large part of the coastal area south of the Coyote Hills uplift was still receiving marine deposits. Older alluvium elevated over the Coyote Hills uplift stands above the level of the coastal area and is dissected by streams anteceding the uplift.

Deposits of older alluvium near the town of Yorba Linda and westward have been dissected by the Santa Ana River and its tributaries. The Santa Ana River has cut into the older alluvium south of the Yorba Linda quadrangle, to form bluffs as much as 65 feet high. Streams issuing from the Puente Hills have also dissected the older alluvium and meet the flood plain of the Santa Ana River at grade. The streams flowing south from the Puente Hills once occupied alluvium-floored valleys wider than their present channels, but later they incised deep narrow gullies into the older alluvium. An example is Carbon Canyon Creek, which formerly flowed in a wide channel across the old fan surface in front of the hills, but which now occupies a much narrower channel just east of its old course.

\section{WHITTIER FAULT ZONE}

The topographic expression of the Whittier fault zone varies considerably from place to place. West of Horseshoe Bend the zone is marked by a break in the general slope of the hills, elevations in the foothills southwest of the fault zone being generally lower than the elevations just northeast of it. The fault zone is also marked by a general alinement of valleys and ridges along its trace.

The courses of the larger streams that cross the fault in the eastern Puente Hills are offset to the west along the fault zone. These offsets have been attributed both to the greater ease with which the crushed beds close to the fault are eroded (English, 1926, p. 65) and to lateral slip along the fault zone (Hill, 1954, p. 10). The latter interpretation is supported by the uniform direction of the offsets.

\section{ECONOMIC GEOLOGY}

Petroleum is the chief mineral resource of the Puente Hills. The cumulative production of crude oil as of December 31, 1957, from seven fields in, or partly in, the map area was more than 470 million barrels.

Production statistics and the nomenclature of oil fields used in this report (table 2) are from the Conservation Committee of California Oil Producers, Annual Review of California Crude Oil Production for 1957 (1958). The nomenclature of oil zones (fig. 17) is from Wissler (1958). Data on reserves are from Stockman (1957). Semiannual and cumulative production figures and detailed descriptions of individual fields are published semiannually by the California Division of Oil and Gas. This agency has also published reports on oil fields along the Whittier fault zone (Norris, 1930), and the Chino-Soquel and Mahala oil fields (Gaede and Dosch, 1955), and the Yorba Linda oil field (Barger and Gaede, 1956). Reports on the East Coyote oil field (Dudley, 1943), the Richfield oil field (Gardiner, 1943), the Yorba Linda oil field (Parker, 1943), and the Mahala oil field (Krueger, 1943) appear in Bulletin 118 of the California Division of Mines. Reports on the Yorba Linda oil field (Heath, 1958), the Mahala oil field (Michelin, 1958), and the western end of the Brea-Olinda oil field (Scribner, 1958) were published by the Pacific Section of the American Association of Petroleum Geologists.

The first commercial production of oil in the Los Angeles basin was obtained in 1885 at the old Puente oil field, which was in the northwestern part of the present Brea-Olinda oil field. The old Puente field and others discovered prior to 1901 in the Puente Hills area were found by drilling near tar seeps occurring along the Whittier fault zone. Geological principles were applied to petroleum exploration in California as early as 1900, and by 1908, when the West Coyote oil field was discovered, study of surface geology was dominating the search for oil (Hoots and Bear, 1954, p. 5). Nearly all the structural features having surface expression in the Los Angeles basin were tested by 1930 , and exploratory drilling in the area was practically at a standstill in the early 1930's; however, with the introduction of geophysical and other subsurface methods, drilling activity was renewed. Most of the oil discovered in the Los Angeles basin since the early 1940's was found by extending or deepening existing fields after careful analysis of subsurface data.

\section{BREA-OLINDA OIL FIELD}

The Brea-Olinda oil field, which is about 5 miles long and averages 0.8 mile in width, is along the Whittier fault zone northwest of the village of Olinda. Only the eastern part of the field is in the map area. 


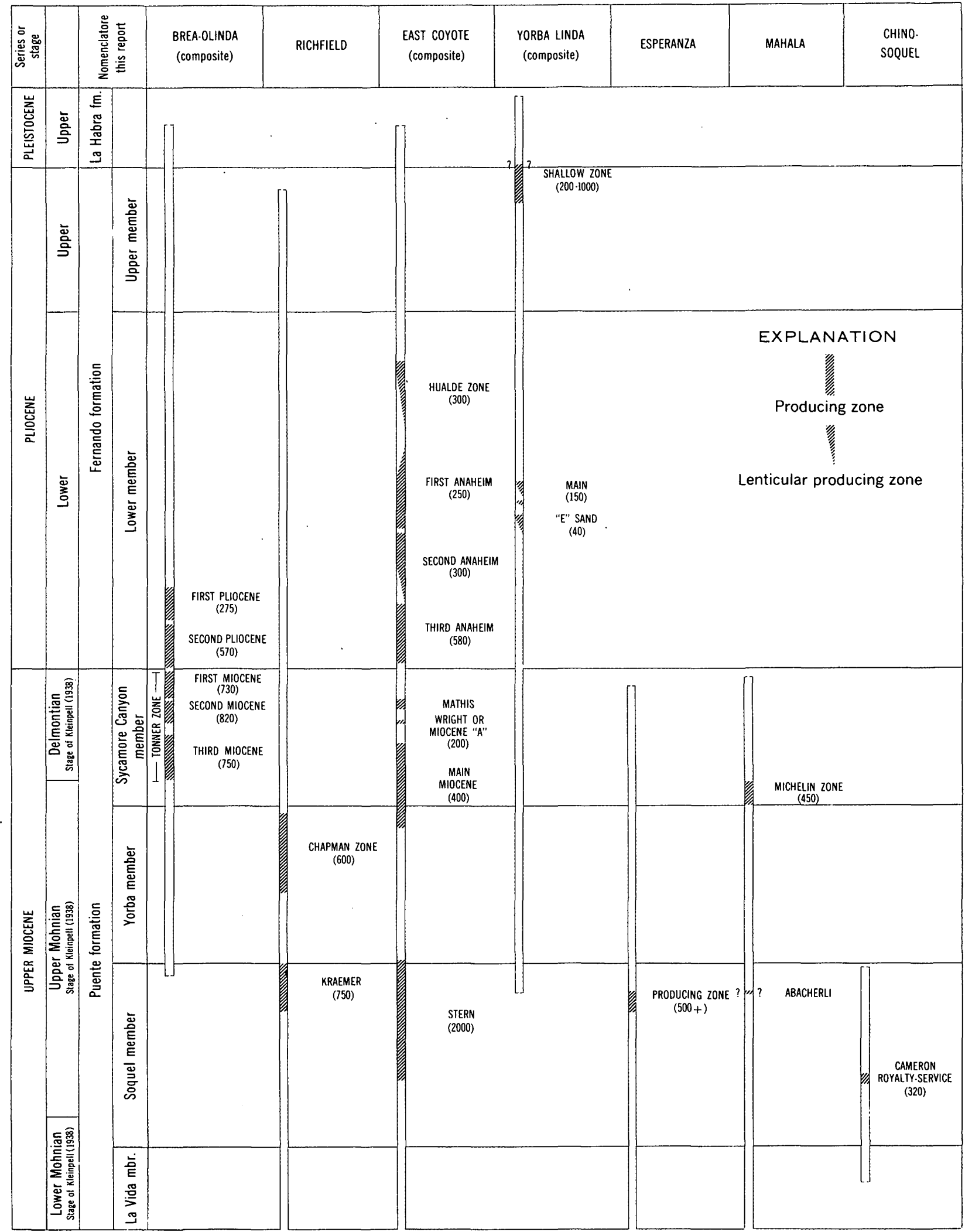

FigUre 17.-Correlation chart of the producing zones in the oil fields in the eastern Puente Hills area. Columns are composite and combine several parts of each field. Each column shows approximate stratigraphic penetration of field. Figures in parentheses are average thicknesses of producing zones, in feet. Not to scale. Modified from Wissler (1958). 
TABLE 2.-Production and reserves of oil fields in the eastern Puente Hills area

[Production statistics from Conservation Committee of California Oll Producers (1958), Annusl review of California crude oil production. for 1957. Productive acreage figures
from Callfornta Division of Oll and Gas, Summary of operations, v. 43, no. 2, 1957. Reserve flgures from Stockman (1957)]

\begin{tabular}{|c|c|c|c|c|c|c|c|c|}
\hline Oll field & $\begin{array}{l}\text { Year of } \\
\text { discovery }\end{array}$ & $\begin{array}{c}\text { Year of } \\
\text { greatest } \\
\text { production }\end{array}$ & $\begin{array}{l}\text { Production } \\
\text { in 1957 } \\
\text { (thousands } \\
\text { of barrels) }\end{array}$ & $\begin{array}{c}\text { Total pro- } \\
\text { duction as of } \\
12 / 31 / 57 \text { (thou- } \\
\text { sands of } \\
\text { barrels) }\end{array}$ & $\begin{array}{l}\text { Reserves } \\
\text { (thousands } \\
\text { of barrels) }\end{array}$ & $\begin{array}{l}\text { Number of } \\
\text { producing } \\
\text { wells, as of } \\
12 / 31 / 57\end{array}$ & $\begin{array}{l}\text { Number of } \\
\text { productive } \\
\text { acres, as of } \\
12 / 31 / 57\end{array}$ & $\begin{array}{l}\text { Gravity of oll } \\
\text { (degrees API) }\end{array}$ \\
\hline $\begin{array}{l}\text { Brea-Olinda } \\
\text { Richfield } \\
\text { East Coyote. } \\
\text { Yorba Linda. } \\
\text { Esperanza. } \\
\text { Mahala } \\
\text { Chino-Soquel }\end{array}$ & $\begin{array}{c}1897-1899 \\
1919 \\
1911 \\
1937 \\
1956 \\
1955 \\
1951\end{array}$ & $\begin{array}{l}1953 \\
1922 \\
1922 \\
1957 \\
1957 \\
1957 \\
1951\end{array}$ & $\begin{array}{r}6,850 \\
2,112 \\
2,175 \\
1,591 \\
87 \\
161 \\
12\end{array}$ & $\begin{array}{r}257,902 \\
131,440 \\
76,644 \\
6,850 \\
91 \\
317 \\
134\end{array}$ & $\begin{array}{r}79,388 \\
24,316 \\
24,385 \\
14,983 \\
1,500 \\
544 \\
25\end{array}$ & $\begin{array}{r}632 \\
429 \\
298 \\
205 \\
7 \\
14 \\
9\end{array}$ & $\begin{array}{r}2,415 \\
1,480 \\
1,250 \\
540 \\
10 \\
90 \\
35\end{array}$ & $\begin{array}{r}\text { 18. } 4-29.3 \\
\text { 18. } 5-22.5 \\
\text { 21. } 2-24.2 \\
\text { 12. } 7-17.3 \\
26.5 \\
22-26.5 \\
22.3\end{array}$ \\
\hline Total & 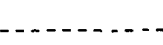 & $\ldots \ldots$ & 12,988 & 473,378 & 145,141 & 1,594 & 5,820 & $\ldots \ldots$ \\
\hline
\end{tabular}

Tar seeps in steeply dipping strata of the Fernando formation prompted exploration that led to the discovery of commercial oil production in the Olinda area in 1897 and in the Brea Canyon area, 3 miles farther northwest, in 1899. At the time of their discovery, these two areas were considered to be separate fields, but the intervening area was proved productive by 1913, when the field was the principal producing area in southern California. Except for the years between 1918 and 1928, development of the Brea-Olinda field has been fairly steady.

In the mid-1950's, drilling activity was concentrated in the western part of the field, where production is obtained from strata of late Miocene age, and in the area south of Tonner Canyon, where production is obtained from rocks of Pliocene age. Many of the more modern wells in the field were directionally drilled. Of 7 companies active in the field during 1957, 2 had about 75 percent of the production and did nearly all of the development drilling.

Most of the wells in the part of the Brea-Olinda oil field in the Yorba Linda quadrangle are south of the Whittier fault zone, where strata of the Fernando formation are exposed. The wells produce from 3 zones in sandstone beds of the lower member of the Fernando formation and from 3 zones in the Sycamore Canyon member of the Puente formation (plate 2).

Wells in the Brea-Olinda oil field have not been drilled through the Soquel member of the Puente formation. Several wells drilled north of the fault zone and just west of the Yorba Linda quadrangle penetrated metamorphic basement rocks that are unconformably overlain by the Topanga formation at depths of 3,300 to 3,400 feet below sea level (Scribner, 1958, p. 106-107).

Production in the part of the Brea-Olinda oil field in the Yorba Linda quadrangle comes from strata of late Miocene and Pliocene age on the steeply dipping and faulted northern flank of the La Habra syncline.
Faults in or related to the Whittier fault zone dominate the structure in the Brea-Olinda oil field. Closure to the north is provided by slivers of older strata that are thrust up along the fault zone. The structural high of the field south of the Whittier fault zone is about 1 mile west of the boundary of the Yorba Linda quadrangle.

\section{RICHFIELD OIL FIELD}

The Richfield oil field is on the easternmost of the anticlines near the Coyote Hills uplift. The field is about 3 miles long and averages about 1 mile in width. Most of the productive acreage in the field is in the Yorba Linda quadrangle, but some production is obtained from a subsidiary structural feature farther south. The structural feature at the Richfield oil field is older than many of those in the Los Angeles basin area, and it is one of the few there that have little or no topographic expression.

Initial exploration at the Richfield oil field was prompted by the occurrence of gas in a water well there. The discovery well was completed in 1919 at a depth of 3,025 feet in strata of the Yorba member of the Puente formation. The field was developed rapidly, and in 1922 it contained 180 wells and was producing 22,780 barrels of crude oil per day.

Development in the main part of the Richfield oil field since 1944 has been concentrated on a secondary recovery program on the west side of the field.

Rocks of premiddle Miocene age assigned to the Vaqueros and Sespe formations, and the Topanga formation of middle Miocene age, were found in the deepest well drilled in the Richfield oil field. This sequence of pre-upper Miocene strata is at least 2,300 feet thick. The oil-producing zones in the Richfield oil field are in the Puente formation of late Miocene age. The Puente formation is about 5,100 feet thick at the field and is overlain by the Fernando formation of Pliocene age. The lower member of the Fernando formation is only about 750 feet thick at the Richfield 
oil field, less than half of its thickness in nearby areas. This thinning of the lower member, which may explain the absence of producing zones in the Pliocene rocks at the Richfield oil field, is attributed to uplift of the anticline at the field in Pliocene time. The upper member of the Fernando formation, which is also thinner at the Richfield oil field than it is in nearby areas, is about 900 feet thick. It overlies the lower member unconformably. The Fernando formation is in turn overlain unconformably by a sequence of Pleistocene and Recent strata about 1,000 feet thick. Strata of the La Habra formation of late Pleistocene age are folded on the southern and western flanks of the Richfield oil field, indicating that the fold is at least in part of late Pleistocene or younger age. Alluvial deposits that unconformably overlie older strata at the field are undeformed.

The main part of the Richfield oil field, as delineated by structure contours drawn at the top of the Chapman zone (Gardiner, 1943, p. 359), is elliptical in outline. The western half of the doubly plunging axis of the anticline trends west, and the eastern half trends N. $65^{\circ} \mathrm{E}$. Structure contours drawn at the top of the Chapman zone show 500 feet of closure in the western part of the field. The axial plane of the anticline dips about $70^{\circ}$ south, which places the structural high of the Kraemer zone about 400 feet south of the structural high of the Chapman zone (Gardiner, 1943). The main anticline is bordered on the southeast by a faulted syncline, which separates it from a small producing anticline south of the Yorba Linda quadrangle.

\section{EAST COYOTE OIL FIELD}

The East Coyote oil field is on the Coyote Hills uplift. It consists of five comparatively small domelike structural features that are elliptical in plan and are alined approximately end-to-end on an east-trending, slightly sinuous axis about 5 miles long. Only the eastern part of the field is in the map area. The structural features in the Yorba Linda quadrangle have very little surface expression, but the Hualde dome, farther west, is a topographic high with marine strata of early Pleistocene age exposed in the center. The part of the field in the Yorba Linda quadrangle is bounded on the north by the La Habra syncline and is probably separated from the Yorba Linda oil field to the east by one or more concealed faults.

The East Coyote oil field was discovered in 1911 by a well drilled on an eastward projection of the axis of the West Coyote oil field. The discovery well did not find an extension of the anticline in the West Coyote oilfield, but instead it found the northern flank of a separate structural feature, the Anaheim dome. The field was developed rapidly by many operators. Ad- ditional oil was discovered in 1934 in a deeper zone in the Stern area at the western end of the field, and in 1936 at the extreme eastern end of the field. More recent drilling in the Yorba Linda quadrangle extended the productive area on the flanks of the Anaheim dome in the central part of the field. Development in the eastern part of the field reached a peak in 1922, when 22,713,700 barrels of crude oil was produced.

The rocks penetrated by wells drilled in the eastern part of the East Coyote oil field range in age from late Miocene to Recent (pl. 3). The base of the Puente formation has not been completely penetrated by wells drilled in the eastern part of the field, where the formation is more than 5,600 feet thick. The Puente formation is overlain by the lower member of the Fernando formation, which is 1,400 to 1,800 feet thick, and this in turn is overlain by the upper member of the Fernando formation, which is 1,000 to 1,300 feet thick. The Fernando formation is concealed beneath Pleistocene and Recent strata as much as 1,000 feet thick.

At least three separate domelike features can be outlined in the eastern part of the East Coyote oil field by structure contours drawn at the top of the Second Anaheim zone (Dudley, 1943, p. 353). These are: (1) the eastern of the two structural highs that together are named the Anaheim dome; (2) a smaller structural high to the east, near the southwest corner of sec. 18 , T. 3 S., R. 9 W.; and (3) a small structural high, near the southwest corner of sec. 17 , T. 3 S., R. $9 \mathrm{~W}$., that underlies the part of the field called the Eastern area. Dudley (1943, p. 353) shows the top of the Second Anaheim zone at about 2,500 feet below sea level on the first two structural highs and at about 3,000 feet below sea level on the third. A line drawn through the crest of these three structural highs trends N. $84^{\circ} \mathrm{W}$. The field is probably bounded on the east by a buried fault that trends about N. $30^{\circ} \mathrm{E}$. near the northwest corner of sec. 21, T. 3 S., R. 9 W. The block on the west side of this fault appears to be downdropped about 500 feet. Concealed cross faults may also be present between the Anaheim dome and Eastern area.

The upper member of the Fernando formation of late Pliocene age does not thin over the structural highs at the East Coyote oil field, indicating that the uplift is probably post-Pliocene in age. The anticline in the eastern part of the field is covered by alluvial deposits and has no surface expression; however, the La Habra formation of late Pleistocene age apparently is folded in this area.

\section{YORBA LINDA OIL FIELD}

The Yorba Linda oil field was considered to be a part of the East Coyote oil field prior to 1952, when it 
was designated as a separate field by the California Division of Oil and Gas. This field, which is roughly triangular in outline and has an area of about 1 square mile, is west and north of the town of Yorba Linda. The field is divided into three areas defined by the different productive oil zones (fig. 17). In the northeastern part of the field, production is from the Shallow zone in rocks of late Pliocene age. In the southern half of the field production is chiefly from the Main zone (also called the Smith zone) in rocks of early Pliocene age. In the northwestern part of the field, production is from the $\mathrm{E}$ Sand zone, which is stratigraphically just below the Smith zone, in rocks of early Pliocene age (Benzley, 1956; Barger and Gaede, 1956 ; Heath, 1958).

The Yorba Linda oil field is of particular interest because of the low-gravity of the oil produced there, which averages about $12.7^{\circ}$ API gravity. This is the only oil produced from strata of late Pliocene age along the northern border of the Los Angeles basin.

Although petroleum exploration began in the Yorba Linda area as early as 1920 , commercial production of oil was not obtained there until 1937. After completion of the initial development of the field in 1944, drilling activity was almost at a standstill until 1954, when production at shallow depth was obtained in the northeastern part of the field. This production is facilitated by use of hot water circulation systems for bottom-hole heating of the oil. Although most of the drilling activity after 1954 was concentrated in the northeastern area of the field, some wells were drilled in the southwestern part of the field for development of the Main zone.

The gross structure at the Yorba Linda oil field is a homocline. Structure contours on the tops of the producing horizons trend about N. $45^{\circ}$ to $50^{\circ} \mathrm{W}$., and the beds dip $10^{\circ}$ to $15^{\circ}$ southwest. The homocline is bounded on the north by a tight flexure or fault, north of which steeply dipping Pliocene and Pleistocene strata are exposed. The southwestern part of the field is underlain by an elongate fault-bounded structural nose that plunges southwestward and has closure of about 700 feet (Barger and Gaede, 1956, pl. 2). The beds in this part of the field were probably uplifted about 500 feet along a fault that strikes approximately N. $30^{\circ} \mathrm{E}$. near the NE. cor. sec. 21, T. 3 S., R. 9 W. The Shallow zone, from which production is obtained in the northeastern part of the field, is a conglomeratic sandstone unit that apparently occupies an old southwestwardtrending channel. The upper surface of the conglomeratic sandstone body is planar and dips $10^{\circ}$ to $15^{\circ}$ $\mathrm{SW}$; the lower surface is concave. The channel apparently slopes to the southwest, where it broadens and disappears.
Strata as young as late Pleistocene in age occur in the homocline at the Yorba Linda oil field. The fold or fault that bounds the field along its northern margin is probably related to the Whittier fault zone:

\section{ESPERANZA OIL FIELD}

The Esperanza oil field, which was discovered in 1956, is in the southeastern part of the Yorba Linda quadrangle just south of the Whittier fault zone. In 1958 its productive area was about 0.8 mile long and 0.4 mile wide.

Most of the wells drilled in the Esperanza oil field begin in steeply dipping beds of the Sycamore Canyon member of the Puente formation and bottom in strata of the Soquel member of the Puente formation. The producing zone occurs at the top of the Soquel member of the Puente formation (fig. 17) and is at an average depth of 2,500 feet. The Sycamore Canyon member is as much as 1,500 feet thick in the vicinity of the field, and the Yorba member has a similar thickness there.

The structure of the beds at the Esperanza oil field is related to and complicated by the nearby Whittier fault zone. Apparently oil is produced from two intensely faulted anticlines that trend about N. $70^{\circ} \mathrm{W}$. (pl. 4) and probably plunge eastward. The axial planes of the folds are almost vertical near the surface, but at depth they probably dip steeply northward.

\section{MAFALA OIL FIELD}

Oil is produced in only two areas northeast of the Whittier fault zone in the eastern Puente Hills. The larger of the two is the Mahala oil field, which lies along the Chino fault in sec. 12, T. 3 S., R. 8 W. The producing area is about 0.8 mile long and 0.3 mile wide.

The first exploratory well near the Mahala oil field was drilled in 1921. Although several wells drilled in this area had good initial production, the production declined rapidly to subcommercial levels. By 1952, the field had produced a total of 21,124 barrels of oil from an area of 10 acres. In 1955 , production was renewed in the area with the completion of a well producing 100 barrels of oil a day from depths of 1,580 and 2,030 feet (Michelin, 1958). By the end of 1957, the field had 11 completed wells and an area of 100 acres.

Wells drilled in the field begin in the basal part of the Sycamore Canyon member of the Puente formation, penetrate the Chino fault, and produce from beds of the same member below the fault.

The Mahala oil field is on a long narrow anticline that is bordered on the northeast by the Chino fault. At 
the surface the flanks of the fold dip about $25^{\circ}$ southwestward and about $35^{\circ} \mathrm{NE}$. The Chino fault intersects wells in the field at an average depth of 1,600 feet.

\section{CHINO-SOQUEL OIL FIELD}

The Chino-Soquel oil field is on a small anticline in sec. 32 , T. 2 S., R. 8 W. The field occupies a triangular area of about 35 acres.

Shallow exploratory wells in the Chino-Soquel oil field area yielded some oil before 1900 , and more was produced there about 1940 . The first well with sustained production was drilled in the area in 1951 and by the end of that year the field had 6 wells producing a total of about 70 barrels of oil a day. In 1958, the field had 9 wells producing a total of about 40 barrels of oil a day. Four producing zones are recognized, all in the Soquel member.

The axis of the anticline at the Chino-Soquel oil field strikes about N. $70^{\circ}$ E. and plunges about $20^{\circ}$ NE. Strata on the northern flank of the anticline dip about $45^{\circ}$ at the surface and $\operatorname{dip}$ at least $17^{\circ}$ at the level of the producing zones (about 1,100 $\mathrm{ft}$ depth); beds on the southern flank dip about $15^{\circ}$ to $20^{\circ}$ at the surface. The anticline is closed at its western end by one of several small cross faults. The productive wells of the field are on the crest and southern flank of the anticline. About 75 feet of closure is shown by structure contours at the top of the Middle MercuryCameron zone (Gaede and Dosch, 1955, pl. 3, p. 36).

\section{SUMMARY OF OIL OCCURRENCE}

Oil is produced in the eastern Puente Hills area from strata of both the Puente and the Fernando formations. The members of both formations that are productive in this area are listed in table 3.

The most productive oil zones in the eastern Puente Hills area are in the lower member of the Fernando formation; however, in this area the occurrence of oil in the upper member of the Fernando formation and in the Yorba member of the Puente formation is of special interest. The only place on the northeastern side of the
Los Angeles basin where oil is produced from the upper member of the Fernando formation is at the Yorba Linda oil field, where it comes from beds that occupy an old stream channel in the upper Pliocene rocks.

The Sycamore Canyon member of the Puente formation ranks second to the lower member of the Fernando formation in the production of oil in the eastern Puente Hills area. It underlies much of the area and is productive or potentially productive, wherever it is present in structural circumstances favorable for oil accumulation. The Yorba member, from which production is not ordinarily obtained in the northeastern part of the Los Angeles basin, is productive in the western part of the Brea-Olinda oil field (west of the Yorba Linda quadrangle), in the Kraemer oil field (south of the Yorba Linda quadrangle), and in the Richfield oil field. At these places the Yorba member contains unusually thick lenses of sand, as it does also where it is exposed north of Horseshoe Bend. The Soquel member, which contains the oldest producing zones in the map area, is predominantly sandstone. It contains productive zones in most of the fields where it occurs and may be potentially productive in other fields where it has not been adequately tested.

Oil has not been produced from the Topanga formation in the eastern Puente Hills area. Good records are available for eight wells that were drilled into the formation in the eastern Puente Hills (table 4). The Western Gulf Oil Co. well Diamond Bar 1 (pl. 1, well 250 , sec. 28 , T. 2 S., R. 9 W.), in the central part of the Yorba Linda quadrangle, penetrated about 4,900 feet of pre-upper Miocene strata (pl. 3) that consist chiefly of well-cemented sandstone, pebbly sandstone, and organic siltstone. A 2-foot bed of oil sand was cored at a depth of 2,746 feet in strata referred to the Diamond Bar sand in the Topanga formation. Cores from the Topanga formation between 3,440 and 5,135 feet were heavily stained with dead oil and tar that gave faint cuts in ether. No signs of petroleum were found in strata in the bottom 1,700 feet of the well. The Union Oil Company well Gaines 1 (pl. 1, well 221, sec. 10, T. 3 S., R. 9 W.), in the south-central part of the Yorba

TABLE 3.-Oil produced in 1957 from members of the Puente and Fernando formations in oil fields in the eastern Puente Hills area [Compiled from Annual review of California crude oil production for 1957, Conservation Committee of California Oil Producers, 1958. See also flg. 17]

\begin{tabular}{|c|c|c|c|c|c|}
\hline Age & Formation & Member & $\begin{array}{c}\text { Production } \\
\text { in } 1957 \\
\text { (thousands } \\
\text { of barrels) }\end{array}$ & $\begin{array}{l}\text { Average } \\
\text { gravity } \\
\text { (degrees } \\
\text { A.P.I.) }\end{array}$ & Fields in which member produces \\
\hline $\begin{array}{l}\text { Late Pliocene } \\
\text { Early Pliocene.... } \\
\text { Late Miocene }\end{array}$ & $\begin{array}{l}\text { Fernando } \ldots . . . \\
\text { Puente }\end{array}$ & $\begin{array}{l}\text { Upper } \\
\text { Lower } \\
\text { Sycamore Canyon } \\
\text { Yorba_. } \\
\text { Soquel }\end{array}$ & $\begin{array}{r}507 \\
6,001 \\
3,325 \\
1,117 \\
2,039\end{array}$ & $\begin{array}{l}12.7 \\
18 \\
21 \\
22 \\
24\end{array}$ & $\begin{array}{l}\text { Yorba Linda. } \\
\text { Brea-Olinda, East Coyote, Yorba Linda. } \\
\text { Brea-Olinda, East Coyote, Mahala. } \\
\text { East Coyote(?), Richfield. } \\
\text { Chino-Soquel, East Coyote, Esperanza, } \\
\text { Mahala, Richfield. }\end{array}$ \\
\hline
\end{tabular}


Linda quadrangle, penetrated about 2,600 feet of strata assigned to the Diamond Bar sand and other beds of the Topanga formation (pl. 3). Cores from the well between 4,050 and 4,520 feet consist of generally well cemented pebbly sandstone and interbedded siltstone and are oil stained. Well-cemented rock in the cores had free oil on fracture surfaces. The Shell Oil Co. well Wright 73-18 (pl. 1, well 184, sec. 18, T. 3 S., R. $8 \mathrm{~W}$.), near the eastern edge of the Yorba Linda quadrangle, penetrated about 3,300 feet of well-cemented strata of the Topanga formation (pl. 4). Cores from this well between 4,620 and 4,650 feet had dead oil stains that gave faint to good cuts in carbon tetrachloride. No other indications of petroleum were found in the pre-upper Miocene strata in this well. The Texas Co. well Carrillo Ranch (NCT-1) 1 (pl. 1, well 208, sec. 30, T. 3 S., R. 8 W.), in the southeastern part of the Yorba Linda quadrangle, drilled through about 400 feet of strata of the Topanga formation consisting of poorly sorted pebbly sandstone with a clay matrix and cemented locally with calcite (pl. 4). The cores had a faint odor of petroleum and gave pale-yellow cuts. The Marcell well Puente Hills 1 (pl. 1, well 108, sec. 31, T. 2 S., R. 8 W.), near the eastern edge of the Yorba Linda quadrangle, drilled through about 1,200 feet of well-indurated siltstone, sandstone, and pebbly sandstone of the Topanga formation (pl. 3). Only two cores were recovered from the Topanga formation in this well and these were saturated with water. The Tidewater Oil Co. well Abacherli 1 (pl. 1 well 212, sec. 12 , T. 3 S., R. 8 W.) on the Mahala anticline in the central part of the Prado Dam quadrangle, was drilled through about 175 feet of siltstone, sandstone, and pebbly sandstone assigned to the Topanga formation. Cores from the upper 60 feet of this interval had a good odor of petroleum and gave good cuts. Cores from the lower part were well cemented, conglomeratic, and barren of petroleum. The Tidewater Oil Co. well Bryant Ranch 1 (pl. 1, well 213, sec. 21, T. 3 S., R. 8 W.), on the Bryant Ranch anticline in the southwestern part of the Prado Dam quadrangle, was drilled for 1,100 feet into a sequence of siltstone, sandstone, and pebbly sandstone beds below 4,800 feet that was assigned to the Topanga formation (pl. 4). Cores from this unit had spotty oil and tar stains and some free oil. A test of the interval from 5,810 to 5,913 feet was made, and 4.00 feet of mud without oil was recovered. The Honolulu Oil Co. well Bryant Estate 1 (pl. 1, well 88, sec. 29 , T. 3 S., R. 8 W.), in the southwestern part of the Prado Dam quadrangle, penetrated approximately 1,500 feet of well-cemented sandstone and pebbly sandstone with interbedded siltstone. These strata are below the Horseshoe Bend fault at a depth of 1,830 feet and are assigned to the Topanga formation. A core taken from this well between 1,997 and 2,011 feet was saturated with oil in porous parts of the rock. No other signs of oil or gas were found in the Topanga formation in the well.

Several wells in the eastern Puente Hills were drilled into the Vaqueros and Sespe formations undifferentiated and older units without finding evidence of oil or gas.

\section{OUTLOOK FOR FUTURE DEVELOPMENT}

Although production is declining in most of the fields in the eastern Puente Hills area, some new production has been found in areas that previously had been considered adequately tested and unproductive. Careful study of the geology of one such area resulted in the discovery of the Esperanza oil field in 1956. New production was found in the Mahala oil field in 1955 , after it had been abandoned as a producing area in 1952. Some of the areas in the eastern Puente Hills that should be considered in the search for oil are discussed briefly below.

The northeastern margin of the Chino basin may be faulted, as suggested by the geologic sections (pls. 3,4) or it may be an old, buried erosion surface. If the Chino basin is the northerly extension of the Elsinore fault trough, the faults that border it on the northeast are probably fairly steep. The margin of the basin may be marked by a series of parallel and comparatively small step-faults that together displace upper Miocene strata 1,000 to 3,000 feet. In either situation, the northeastern edge of the basin has possibilities as a trap of considerable linear extent.

Seven wells were drilled in and about sec. 18, T. 3 S., R. 7 W., during 1957 and the first half of 1958 to test the possibility of extending production from the Mahala oil field southeastward along the Chino fault. Subcommercial oil production was obtained in two of these wells. The Atlantic Oil Co. well Aras 1 (pl. 1, well 7, sec. 18, T. 3 S., R. 7 W.) was completed in April 1957, producing $22^{\circ}$ gravity API oil at the rate of 50 barrels per day, but by February 1958 it averaged only. 8 barrels per day. The Lyle Garner well Government G-G 1 (pl. 1, well 54, sec. 20, T. 3 S., R. 7 W.) was reported to have flowed oil initially and to have sanded up after only 120 barrels of oil were pumped. The well was never successfully completed and was abandoned in July 1957. Both wells apparently produced from beds in the basal part of the Sycamore Canyon member below the Chino fault. An interpretation of the structure of this area illustrated on structure section $\mathrm{H}-\mathrm{H}^{\prime}$ ( $\mathrm{pl}$. 4) shows the part of the Mahala anticline 
in the footwall block of the Chino fault plunging south eastward and dropping about 1,500 feet between structure sections $\mathrm{G}-\mathrm{G}^{\prime}$ and $\mathrm{H}-\mathrm{H}^{\prime}$ (pl. 4) for an apparent southeastward plunge of $10^{\circ}$ or $11^{\circ}$. Significant accumulations of oil in this part of the Mahala anticline seem to depend on closure updip.

Near the southeast corner of the Prado Dam quadrangle, a buried fault east of Scully Hill may form a trap of considerable linear extent along the south flank of the Arena Blanca syncline. The U-Tex Oil Co. well Prado Dam 1 (pl. 1, well 244, sec. 29, T. 3 S., R. 7 W.) may have penetrated this fault at about 2,000 feet and bottomed in strata of pre-middle Miocene age. The well apparently did not find the basal beds of the
Sycamore Canyon member. The well may have cut the Aliso Canyon fault at about 1,050 feet, but the fault does not appear to affect the beds below that point.

The eastward-trending Diamond Bar fault dips northward and forms closure for northward-dipping beds of the Soquel member in SW1/4 sec. 23, T. 2 S., R. 9 W. This feature may form a trap involving as much as 3,000 feet of strata of the Soquel member of the Puente formation.

\section{EXPLORATORY WELLS}

Table 4 lists exploratory wells and selected producing wells that were drilled in the eastern Puente Hills area prior to June $30,1958$.

TABLE 4.-Exploratory wells and selected oil-producing wells drilled in the eastern Puente Hills area before June 30 , 1958 [Section numbers in parentheses indicate projected section. Elevations, depths, and distances in feet. T.D., total depth. All wells abandoned unless otherwise stated under "Remarks." Foraminifera determined by Patsy B. Smith, U.S. Geol. Survey]

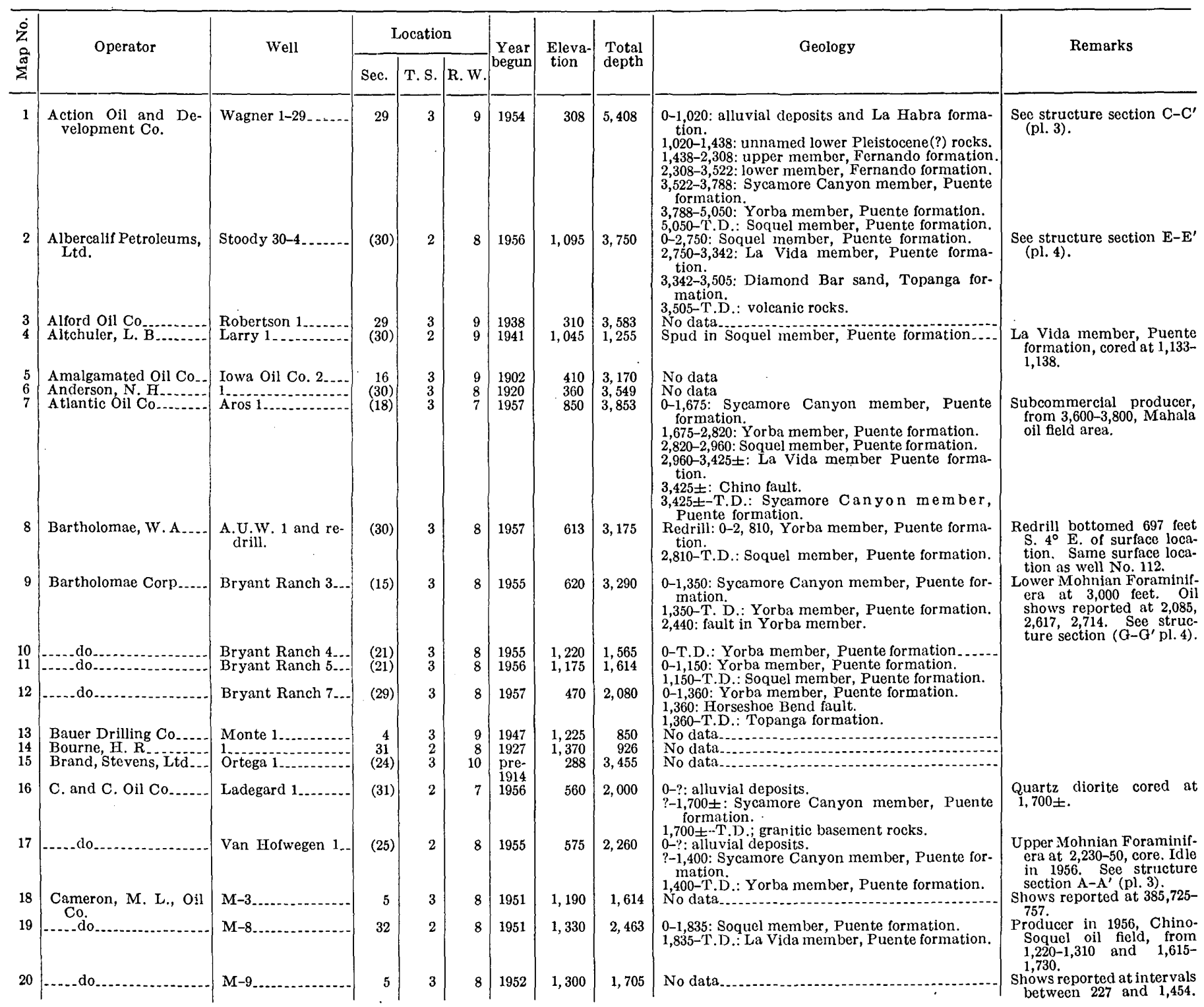


Tante 4.-Exploratory wells and selected oil-producing wells drilled in the eastern Puente Hills area before June $30,1958-\mathrm{Con}$. [Section numbers in parentlicses indicate projected section. Elevations, depths, and distances in feet. T.D., total depth. All wells abandoned unless otherwise stated under "Remarks." Foraminifera determined by Patsy B. Smith. U.'s. Geol. Survey]

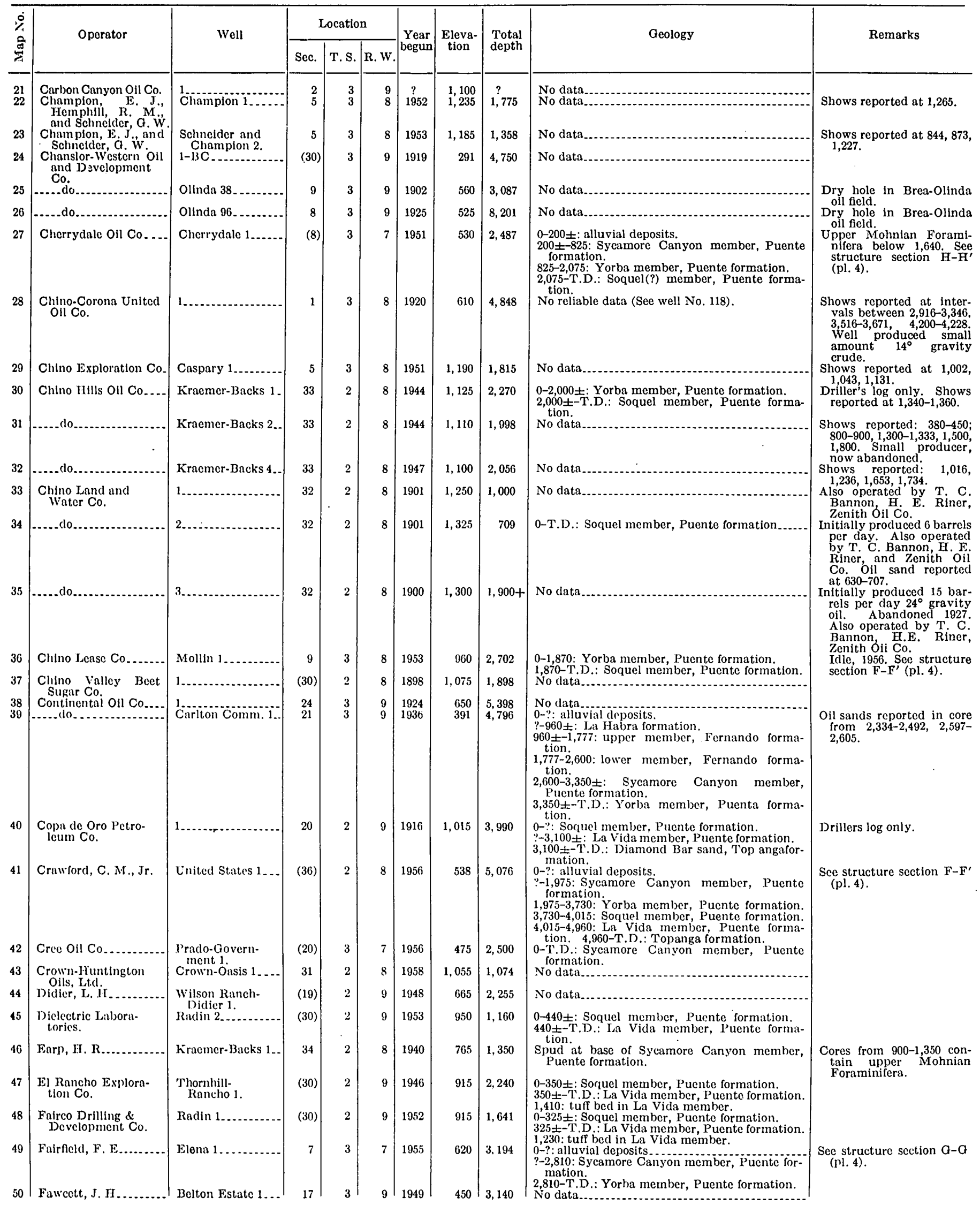


TABLE 4.-Exploratory wells and selected oil-producing wells drilled in the eastern Puente Hills area before June $90,1958-$ Con. [Section numbers in parentheses indicate projected section. Elevations, depths, and distances in feet. T.D., total depth. All wells abandoned unless otherwise stated under "Remarks." Foraminifera determined by Patsy B. Smith, U..S. Geol. Survey]

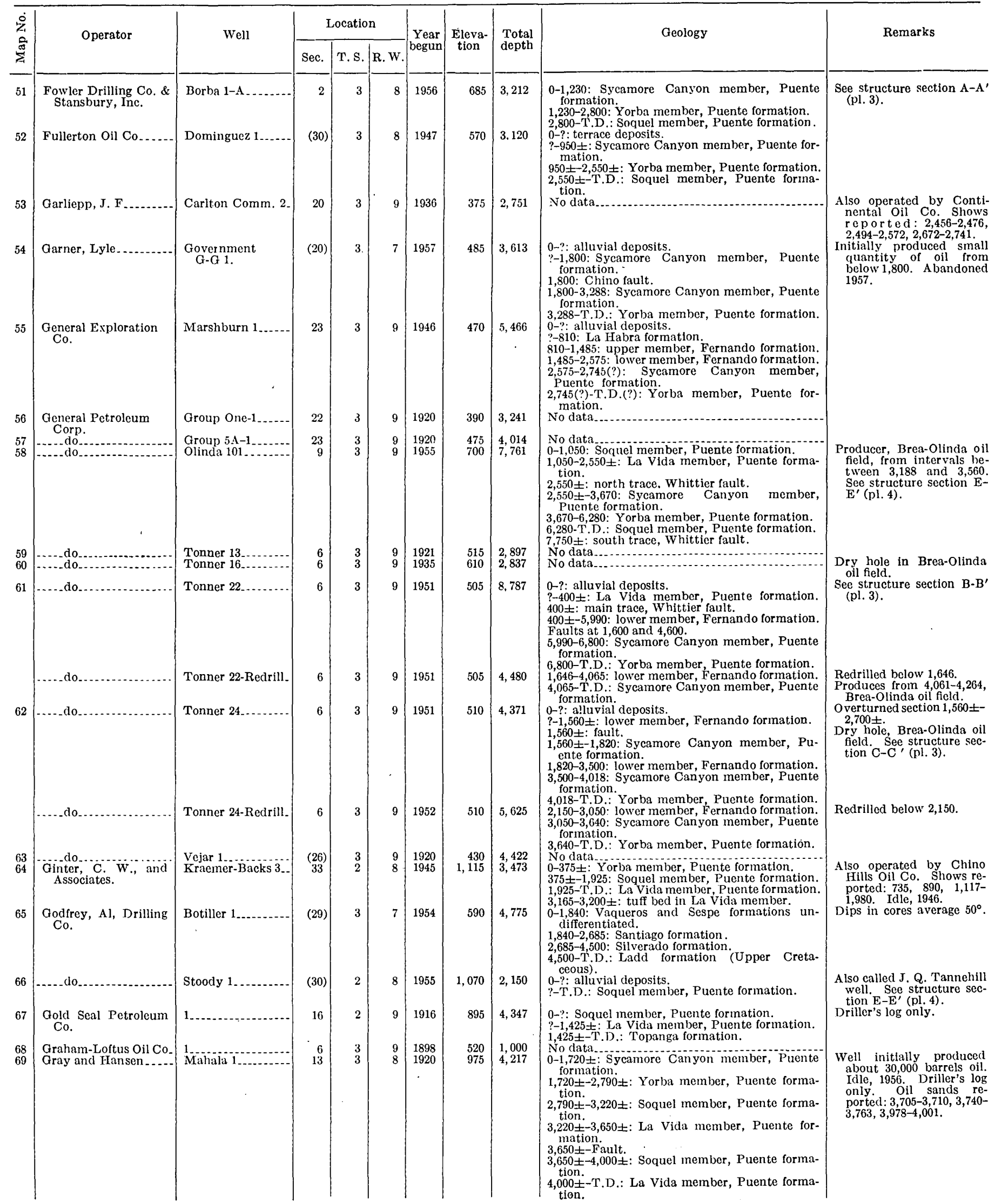


TABLE 4.-Exploratory wells and selected oil-producing wells drilled in the eastern Puente Hills area before June 30, 1958-Con. [Section numbers in parentheses indicate projected section. Elevations, depths, and distances in feet. T.D. total depth. All wells abandoned unless otherwise stated under "Remarks." Forimini fera determined by Patsy B. Smith, U.S. Geol. Survey]

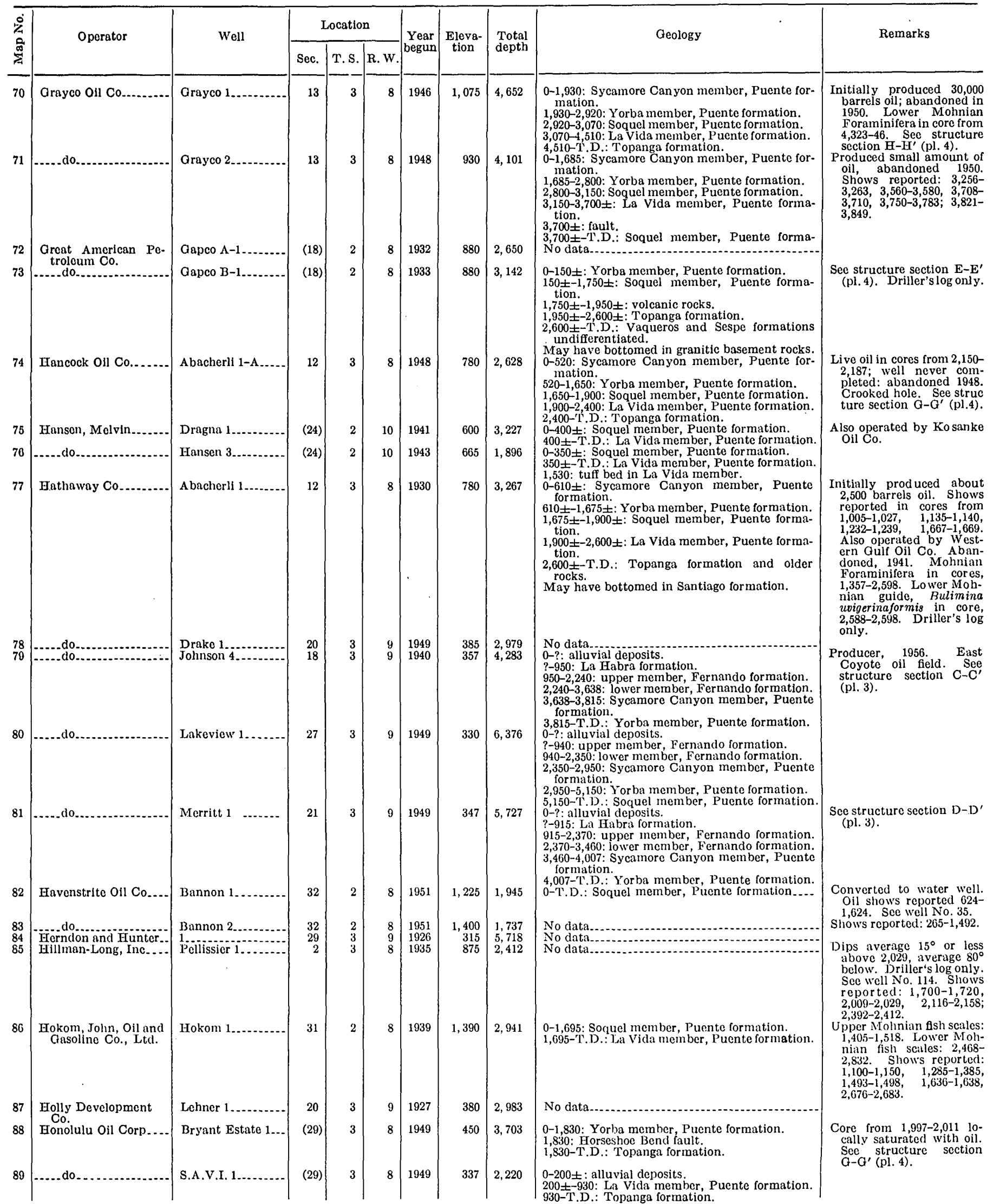


TABLE 4.-Exploratory wells and selected oil-producing wells drilled in the eastern Puente Hills area before June 30, 1958-Con. [Section numbers in parentheses indicate projected section. Elevations, depths, and distances in feet. T.D., total depth. All wells abandoned unless otherwise stated under "Remarks." Foraminifera determined by Patsy B. Smith, U.S. Geol. Survey]




GEOLOGY AND OIL RESOURCES, EASTERN PUENTE HILLS

TABLE 4.-Exploratory wells and selected oil-producing wells drilled in the eastern Puente Hills area before June 30, 1958-Con. [Section numbers in parentheses indicate projected section. Elevations, depths, and distances in feet. T.D., total depth. All wells abandoned unless otherwise stated under "Remarks." Foraminifera determined by Patsy B. Smith, U'S. Geol. Survey]

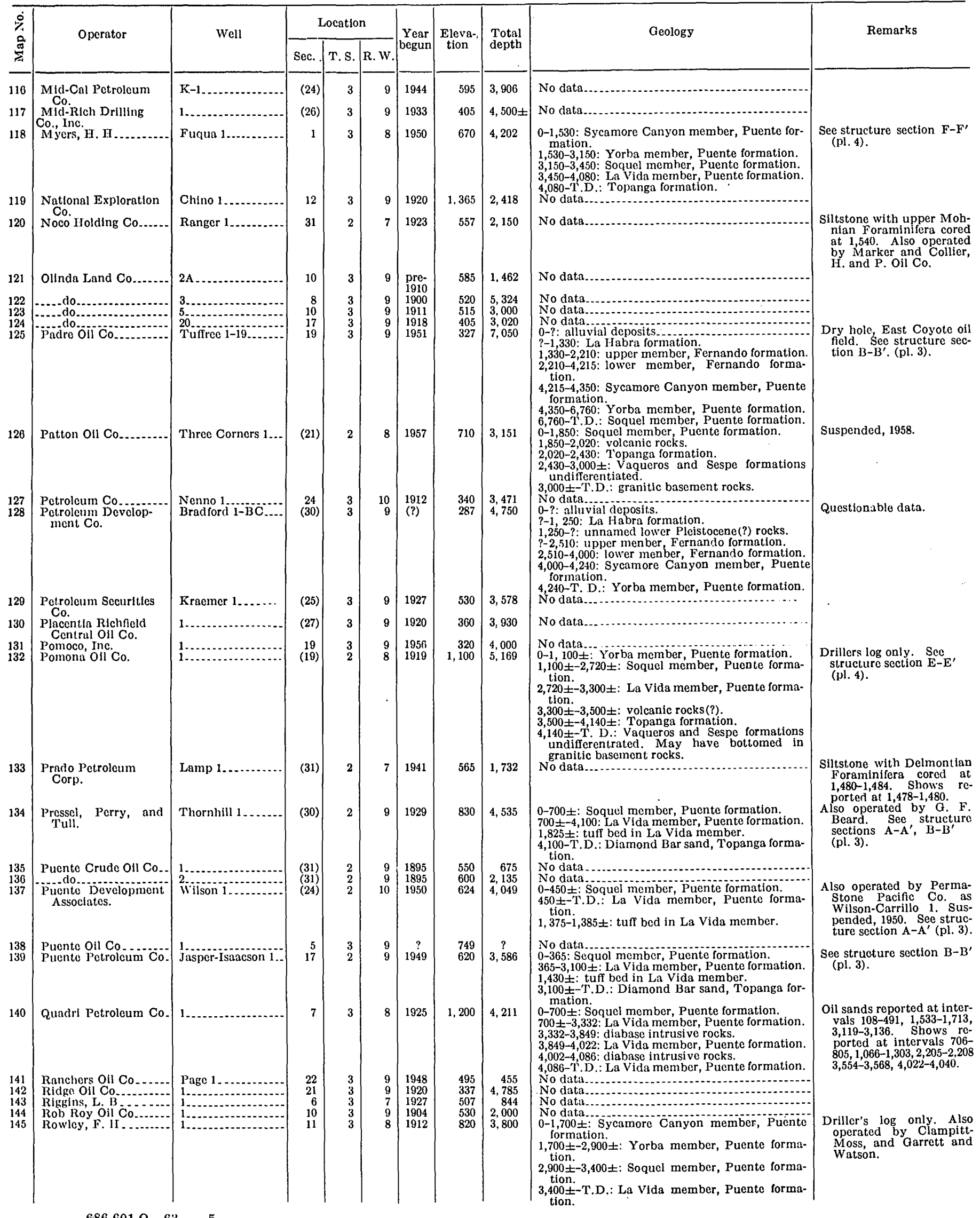


TABLE 4.-Exploratory wells and selected oil-producing wells drilled in the eastern Puente Hills area before June 30, 1958-Con. [Section numbers in paren theses indicate projected section. Elevations, depths, and distances in feet. T.D. total depth. All wells abandoned
unless otherwise stated under "Remarks." Foraminifera determined by Patsy B. Smith, U.S. Geol. Survey]

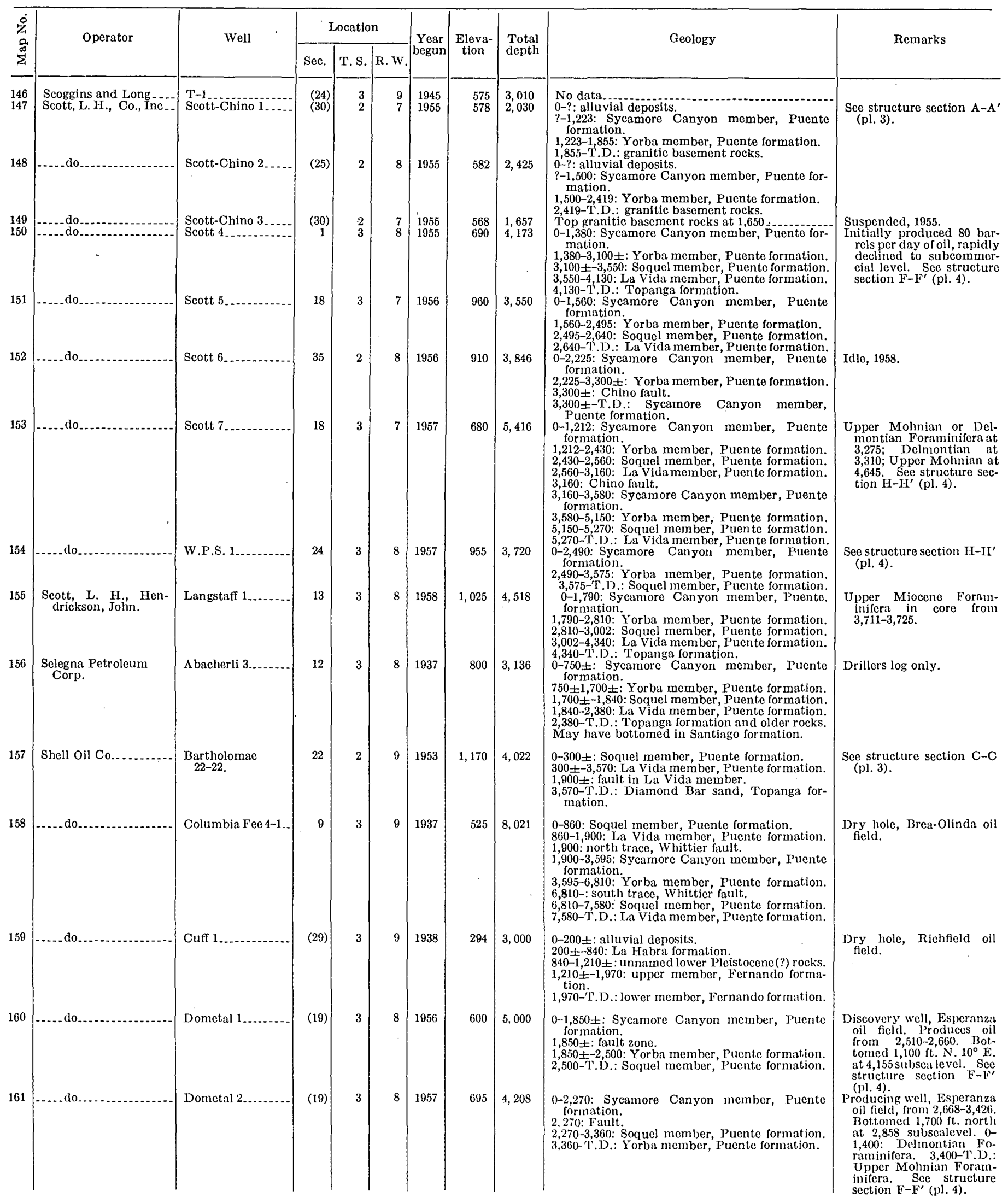


TABLE 4.-Exploratory wells and selected oil-producing wells drilled in the eastern Puente Hills area before June 30, 1958-Con. [Section numbers in parentheses indicate projected section. Elevations, depths, and distances in feet. T.D., total depth. All wells abandoned unless otherwise stated under "Remarks." Foraminifera determined by Patsy B. Smith, Ü.s. Geol. Survey]

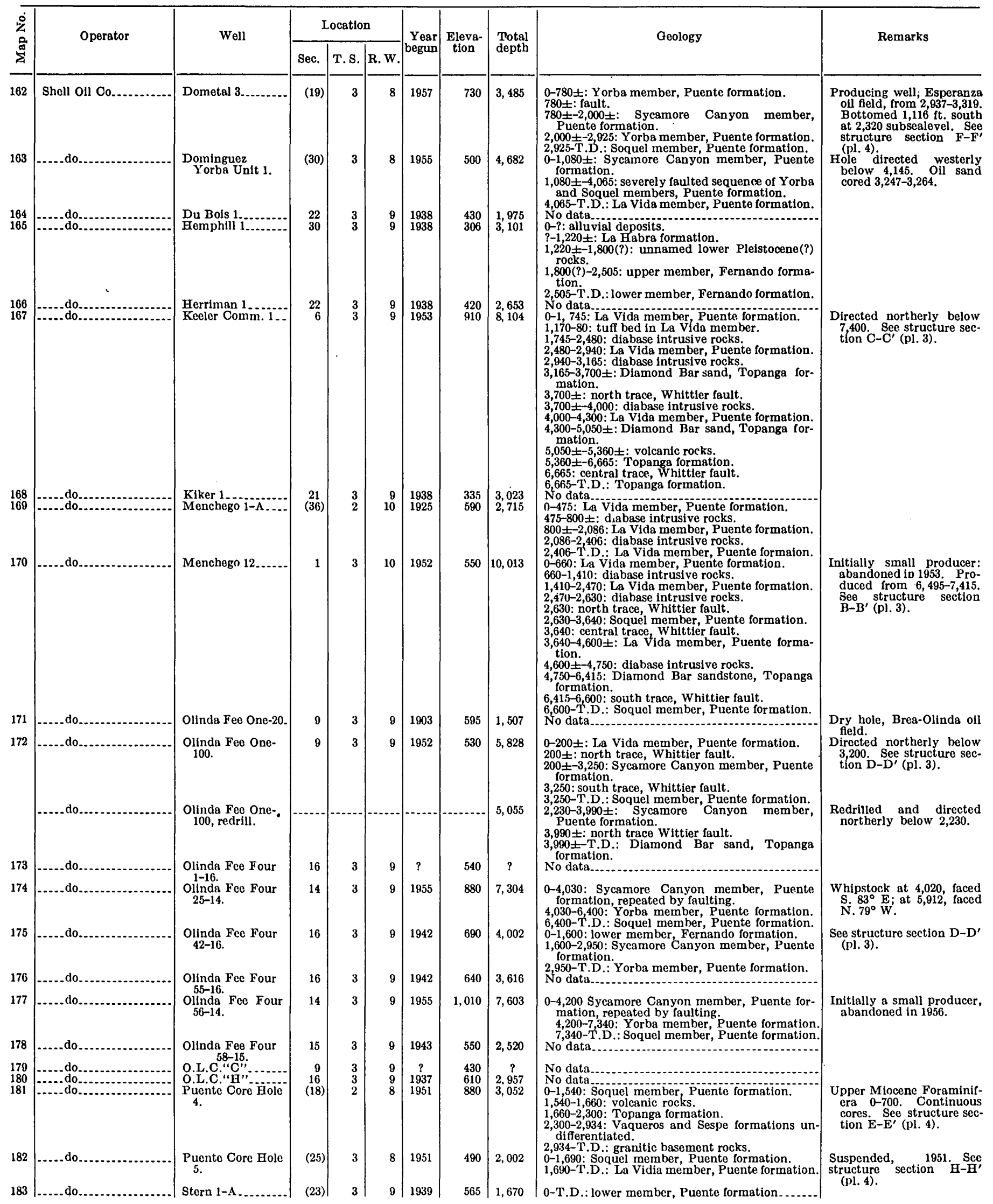


TABLE 4.-Exploratory wells and selected oil-producing wells drilled in the eastern Puente Hills area before June \$0, 1958-Con. [Section numbers in parentheses indicate projected section. Elevations, depths, and distances in feet. T.D., total depth. All wells abandoned unless otherwise stated under "Remarks." Foraminifera determined by Patsy B. Smith, U.S. Geol. Survey]

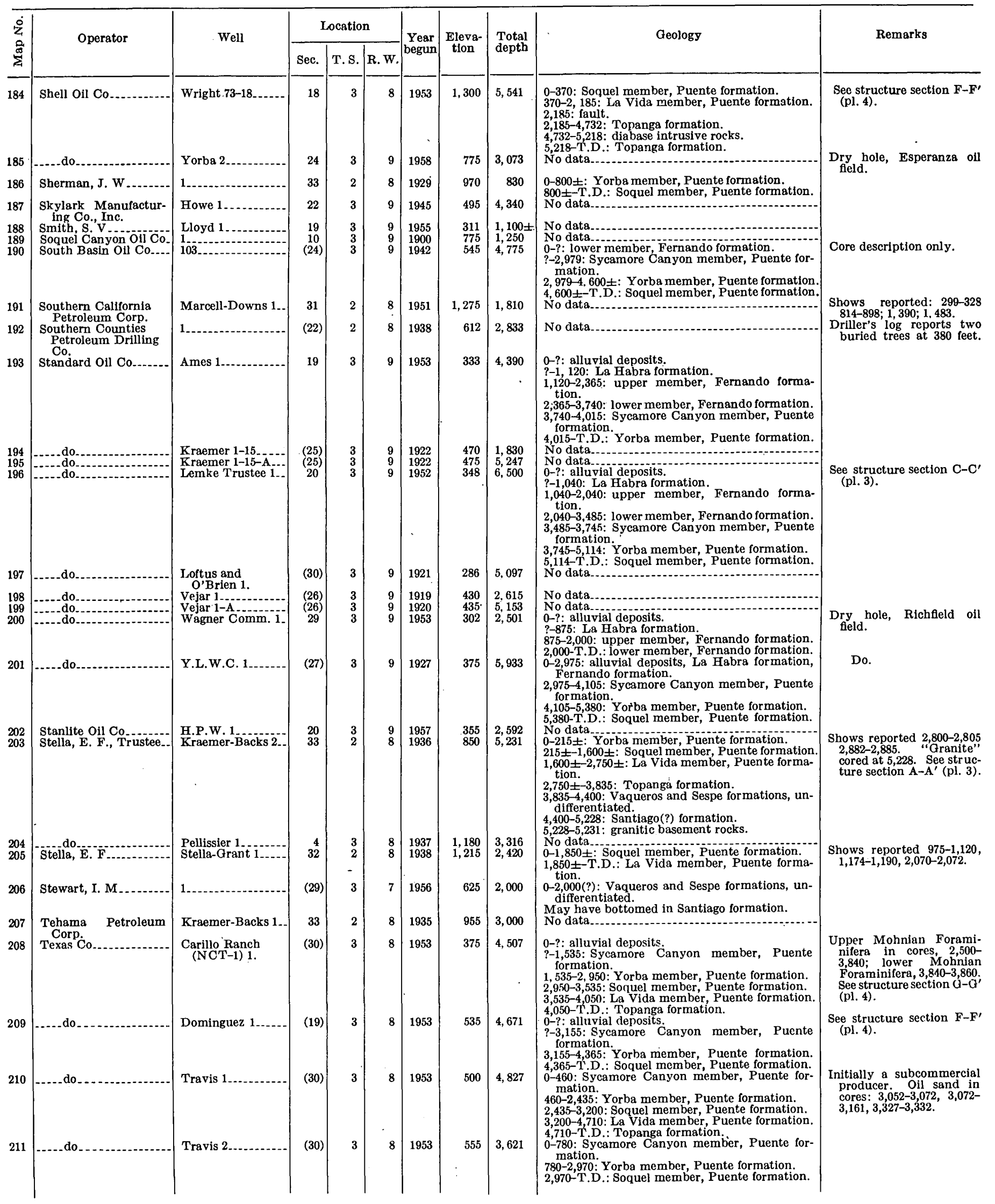


GEOLOGY AND OIL RESOURCES, EASTERN PUENTE HILLS

TABLE 4.-Exploratory wells and selected oil-producing wells drilled in the eastern Puente Hills area before June 30, 1958-Con. [Section numbers in parentheses indicate projected section. Elevations, depths, and distances in feet. T.D., total depth. All wells abandoned unless otherwise stated under "Remarks." Foraminifera determined by Patsy B. Smith, U..S. Geol. Survey]

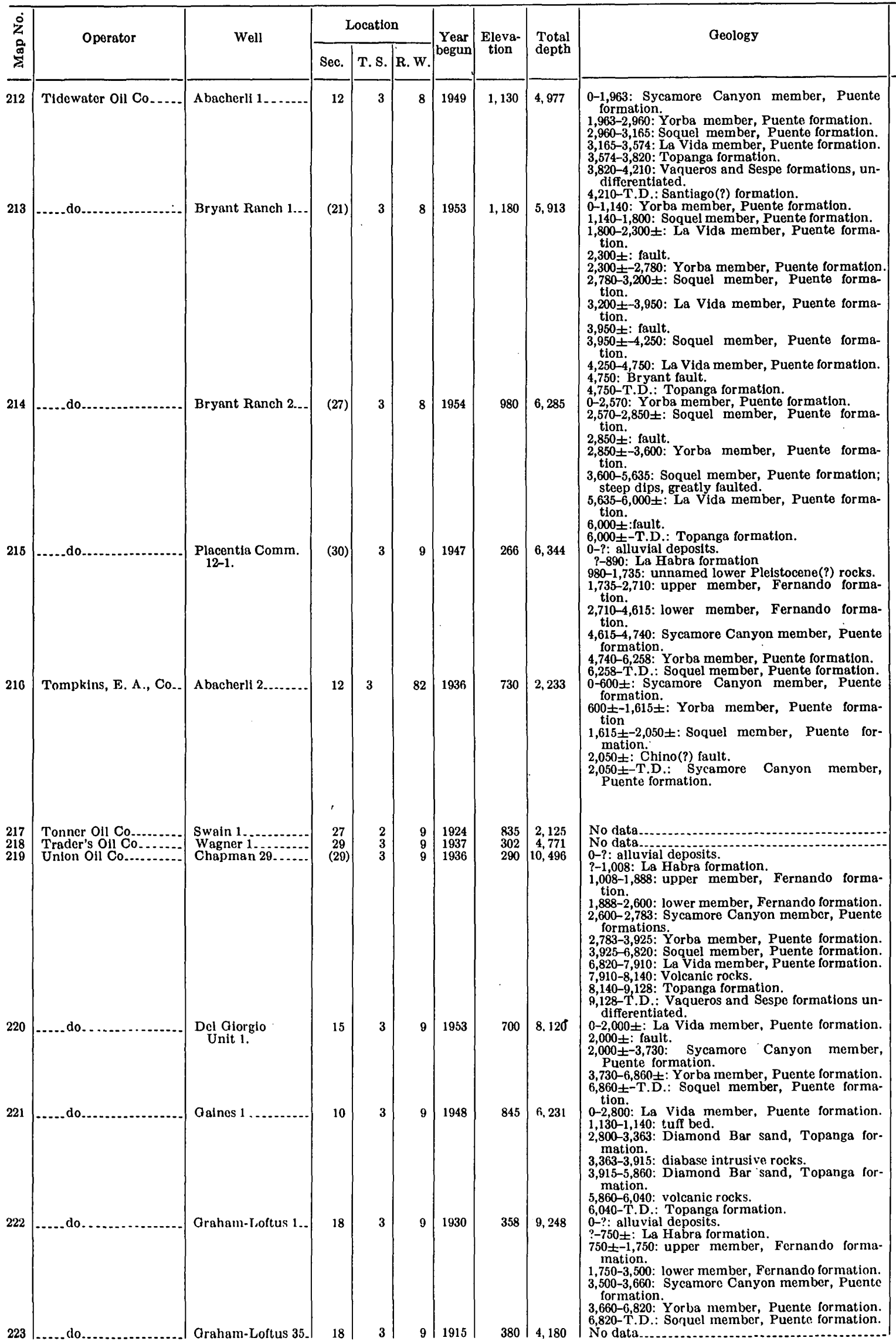

Remarks

Shows reported $2,657-2,667$ $2,686-2,691, \quad 2,856-2,866$ $3,936-2,946, \quad 2,976-2,996$, $3,202-3,211, \quad 3,576-3,607$ 3,628-3,633. See struc-

Upper Mohnian Foraminifera, 992-1,752. Lower $1,895-2,216$. See struc-
ture section $G_{-} G^{\prime}$ (pl. 4).

Delmontian Foraminifera, 0-1,418; Upper Mohnlan Foraminifera, 1,542-2,949 lower Mohnian Foraminifera, 5,690-5,697. On $1,542-1,619, \quad 1,882-1,896$, $3,077,5,280-5,296,5,584-$ 6,215, 6,270-6,277.

See structure section B$\mathbf{B}^{\prime}$ (pl. 3).

Poor data, doubtful interpretation. Steep dips below 1,500; vertical dips at by Chino Petroleum and Melbourne oll Co. Initially produced $40 \mathrm{bar}$ rels of oil per day. Oil shows: $842-859,876-889$ $1,480-1,990, \quad 2,020-2,037$ $\begin{array}{ll}2,041-2,056, & 2-076-2,123,\end{array}$

Producing wcll, Richfield oil fleld. See structure (pl. 3).

Subcommercial producer Geology not verified. Well bottomed $900 \mathrm{ft}$. north-northeast.

Qlassy, basalt cored at $5,900-5,910$. See structur section D-D' (pl. 3).

Producing well, East Coyote oil fleld. See struc\begin{tabular}{l|l} 
3,660-6,820: Yorba member, Puente formation. \\
6,820-T.D.: Soquel member, Puente formation.
\end{tabular} 
TABLE 4.-Exploratory wells and selected oil-producing wells drilled in the eastern Puente Hills area before June 30, 1958-Con. [Section numbers in parentheses indicate projected section. Flevations, depths, and distances in feet. T.D., total depth. All wells abandoned unless otherwise stated under "Remarks." For:minifera determined by Patsy B. Smith, U..S. Geol. Survey]

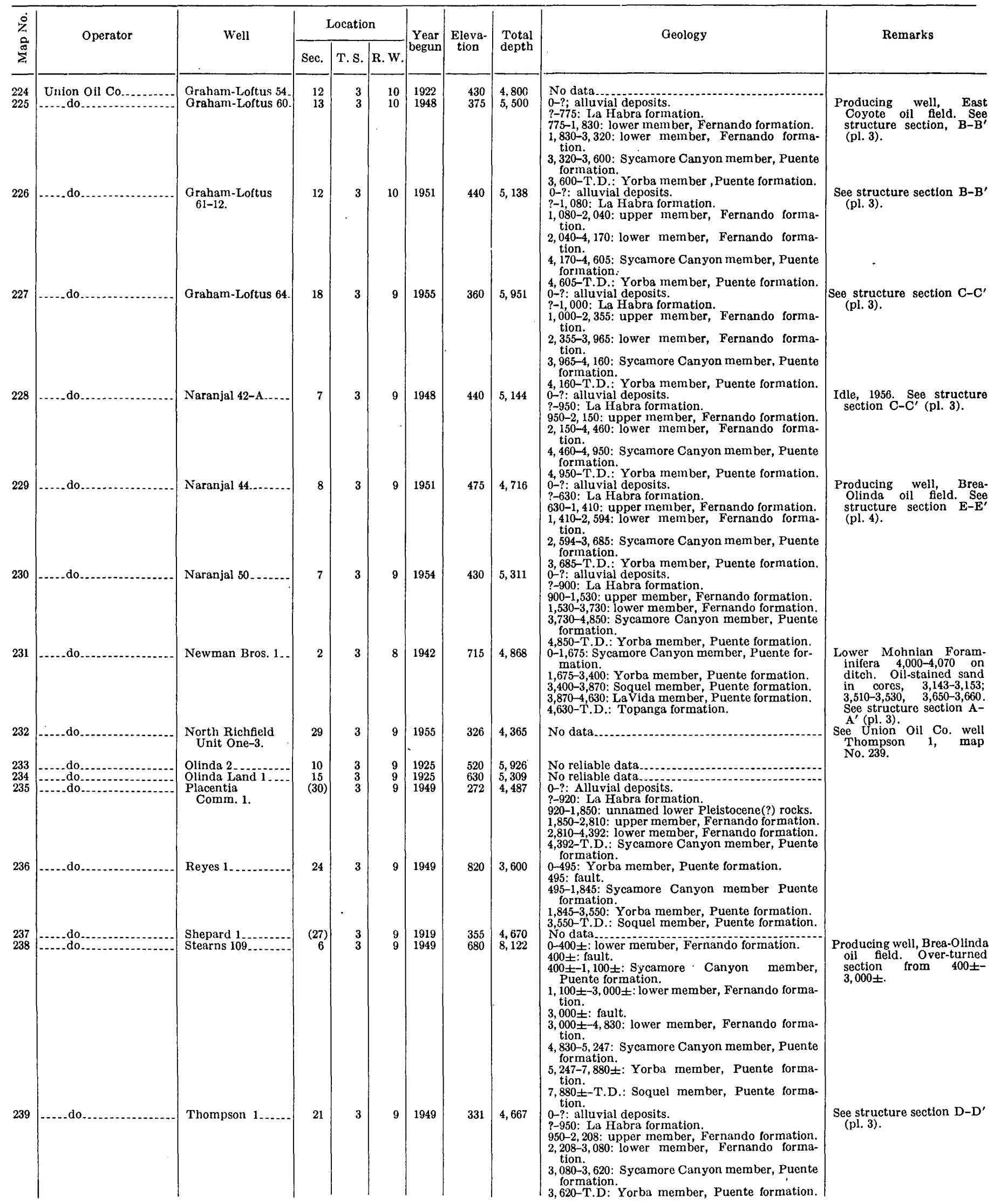


TABLE 4.-Exploratory wells and selected oil-producing wells drilled in the eastern Puente Hills area before June 30, 1958-Con. [Section numbers in parentheses indicate projected section. Elevations, depths, and distances in feet. T.D., total depth. All wells abandoned unless otherwise stated under "Remarks." Foraminifera determined by Patsy B. Smith, U.S. Geol. Survey]

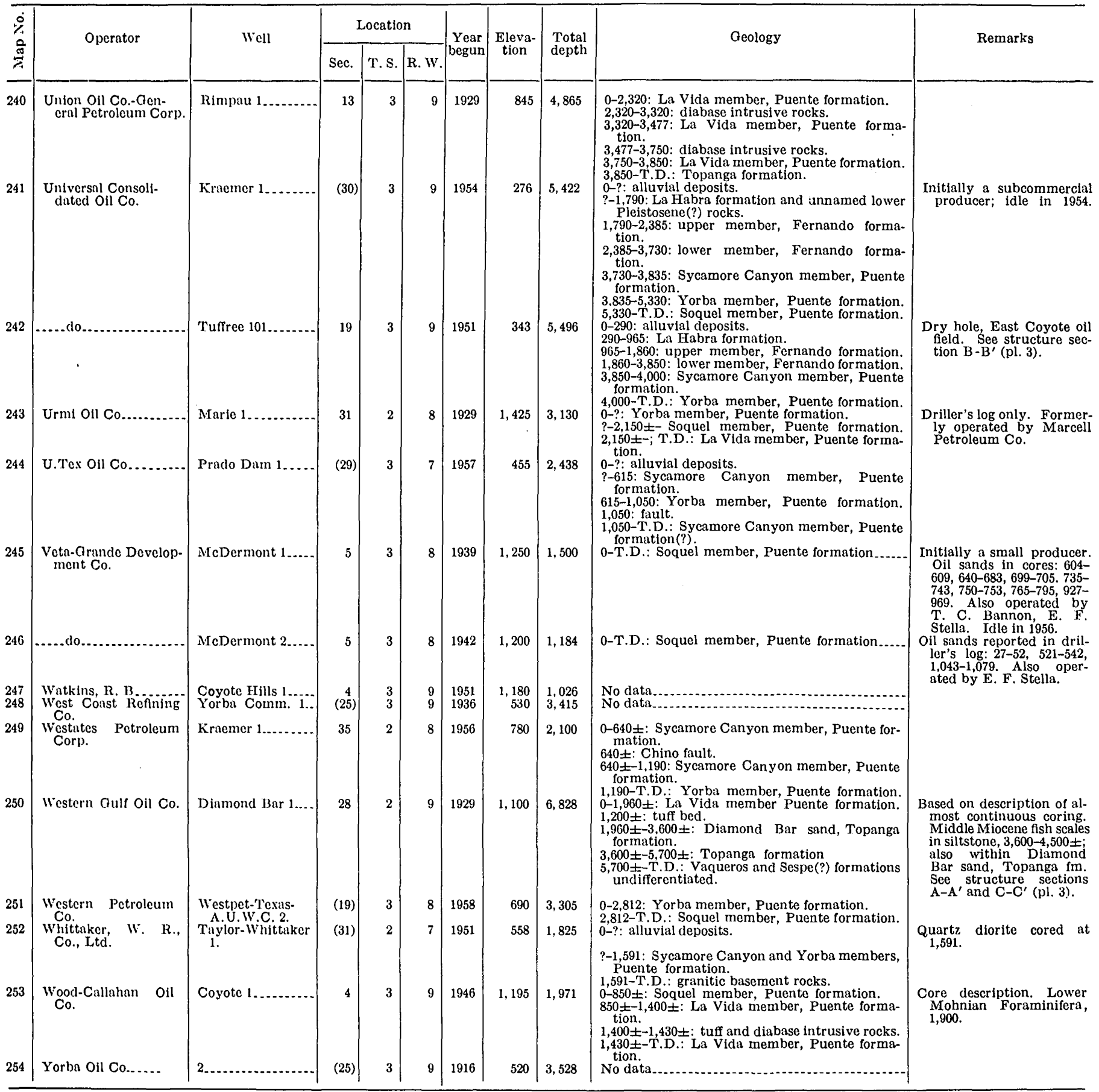

FOSSIL LOCALITIES

The megafossil fatumas from localities listed in this report (table 5) were, with two exceptions, collected by other workers. J. G. Vedder, of the Geological Survey, identified the fossils. Locality $\mathrm{F}-4$ is believed to be in a bed from which a collection was made by
Eldridge (Eldridge and Arnold, 1907, p. 106-107). Faunas from the other localities have not been previously reported. Most of the microfossil collections were made by the authors. References to those made by M. N. Bramlette are from Woodford and others (1944). The fossil localities are shown on the geologic map (pl. 1). 
TABLE 5.-Fossil localities in the eastern Puente Hills area

\begin{tabular}{|c|c|c|}
\hline $\begin{array}{l}\text { Map refer- } \\
\text { ence num- } \\
\text { ber } \\
\text { (pl. 1) }\end{array}$ & Collected by & Description of locality \\
\hline & & MIOCENE SERIES \\
\hline & & Topanga Formation \\
\hline $\mathrm{F}-1 \ldots$ & $\begin{array}{l}\text { D. M. Kinney, } \\
\text { J. E. Schoell- } \\
\text { hamer, E. G. } \\
\text { Heath. }\end{array}$ & $\begin{array}{l}\text { At Horseshoe Bend of Santa Ana } \\
\text { River, } 1,260 \mathrm{ft} \text {. and } 6,210 \mathrm{ft} \\
\text { E. of southwest corner, Prado } \\
\text { Dam quadrangle. }\end{array}$ \\
\hline$F-2 \ldots$ & $\begin{array}{l}\text { D. M. Kinney, } \\
\text { J. E. Schoell- } \\
\text { hamer. }\end{array}$ & $\begin{array}{l}\text { East of Horseshoe Bend of Santa } \\
\text { Ana River, } 2,040 \mathrm{ft} N \text {. and } 7,105 \\
\mathrm{ft} \mathrm{E} \text {. of southwest corner, Prado } \\
\text { Dam quadrangle. }\end{array}$ \\
\hline F-3 & E. G. Heath $\ldots$ & $\begin{array}{l}\text { East of Horseshoe Bend of Santa } \\
\text { Ana River, 1,525 ft } \mathrm{N} \text {. and } \\
6,725 \mathrm{ft} \mathrm{E} \text {. of southwest corner, } \\
\text { Prado Dam quadrangle. }\end{array}$ \\
\hline & & PLIOCENE SERIES \\
\hline & & Fernando Formation \\
\hline F-4 $\ldots$ & $\begin{array}{l}\text { J. G. Vedder, } \\
\text { J. E. Schoell- } \\
\text { hamer, } \\
\text { R. F. Yerkes, } \\
\text { D. L. Durham, } \\
\text { F. R. Goodban. }\end{array}$ & $\begin{array}{l}\text { Ridge south of Tonner Canyon, } \\
65 \mathrm{ft} \mathrm{N} . \text { and } 640 \mathrm{ft} \text { W. of SE. } \\
\text { cor. sec. 1, T. } 3 \mathrm{~S} \text {., R. } 10 \mathrm{~W} \text {., } \\
\text { Yorba Linda quadrangle. } \\
\text { (USGS Cenozic locality M- } \\
746 \text {; Pomona College mega- } \\
\text { fossil locality PC 185.) }\end{array}$ \\
\hline F-5 $\ldots$ & $\begin{array}{l}\text { Ivan Colburn, } \\
\text { W. P. Woodring, } \\
\text { J. E. Schoell- } \\
\text { hamer, } \\
\text { R. F. Yerkes. }\end{array}$ & $\begin{array}{l}\text { West end of ridge north of Yorba } \\
\text { Linda, } 1,585 \mathrm{ft} \text { S. and } 2,395 \mathrm{ft} \\
\mathrm{W} . \text { of } \mathrm{NE} \text {. cor. sec. } 16, \mathrm{~T} .3 \mathrm{~S} \text {, } \\
\mathrm{R} .9 \text { W., Yorba Linda quad- } \\
\text { rangle. (Pomona College mega- } \\
\text { fossil loc. PC } 250 \text {.) }\end{array}$ \\
\hline F-6 & $\begin{array}{l}\text { F. R. Goodban, } \\
\text { Joseph Ernst, } \\
\text { C. J. Kundert, } \\
\text { J. A. Forman. }\end{array}$ & $\begin{array}{l}\text { Small south-draining gully in } \\
\text { hills south of Olinda, } 700 \mathrm{ft} \mathrm{S} \text {. } \\
\text { and } 350 \mathrm{ft} \mathrm{E} \text {. of } \mathrm{NW} \text {. cor. sec. } 16 \text {, } \\
\text { T. } 3 \mathrm{~S} ., \mathrm{R} .9 \mathrm{~W} \text {., Yorba Linda } \\
\text { quadrangle. (Pomona College } \\
\text { megafossil loc. PC 184.) }\end{array}$ \\
\hline $\mathrm{F}-7$ & F. R. Goodban & $\begin{array}{l}\text { South side of Brea-Olinda oil } \\
\text { field, } 2,280 \mathrm{ft} \mathrm{S} \text {. and } 900 \mathrm{ft} \text { W. } \\
\text { of NE. cor. sec. } 7, \mathrm{~T} .3 \mathrm{~S} \text {., R. } 9\end{array}$ \\
\hline $\mathrm{F}-8$ & F. R. Goodban...- & $\begin{array}{l}\text { South side of Brea-Olinda oil } \\
\text { field, } 2,150 \mathrm{ft} \mathrm{S} \text {. and } 1,715 \mathrm{ft} \\
\text { W. of NE. cor. sec. } 7, \mathrm{~T} .3 \mathrm{~S} \text {., } \\
\text { R. } 9 \text { W., Yorba Linda quadrangle. }\end{array}$ \\
\hline & & MIOCENE SERIES \\
\hline & & Puente Formation \\
\hline$f-1$ & $\begin{array}{l}\text { D. M. Kinney, J. } \\
\text { E. Schoellhamer. }\end{array}$ & $\begin{array}{l}\text { South bank Santa Ana River at } \\
\text { Horseshoe Bend, } 110 \mathrm{ft} \mathrm{N} \text {. and } \\
4,390 \mathrm{ft} \text { E. of southwest corner, } \\
\text { Prado Dam quadrangle. }\end{array}$ \\
\hline$f-2 \ldots$ & R. F. Yerkes... & $\begin{array}{l}\text { Roadcut, Carbon Canyon, } 1,820 \\
\text { ft N. and 1,530 ft E. of SW. } \\
\text { cor. sec. 10, T. } 3 \mathrm{~S} \text {., R. } 9 \text { W., } \\
\text { Yorba Linda quadrangle. }\end{array}$ \\
\hline$f-3 \ldots$ & R. F. Yerkes & $\begin{array}{l}\text { Roadcut on ridge southeast of } \\
\text { Tonner Canyon, } 775 \mathrm{ft} \mathrm{N} \text {. and } \\
3,740 \mathrm{ft} \mathrm{W} \text {. of SE. cor. sec. } 5 \text {, } \\
\text { T. } 3 \mathrm{~S} \text {., R. } 9 \text { W., Yorba Linda } \\
\text { quadrangle. }\end{array}$ \\
\hline $\mathrm{f}-4 \ldots$ & R. F. Yerkes & $\begin{array}{l}\text { Roadcut on ridge southeast of } \\
\text { Tonner Canyon, } 890 \mathrm{ft} \mathrm{N} \text {. and } \\
145 \mathrm{ft} \mathrm{E} \text {. of } \mathrm{SW} \text {. cor. sec. } 5 \text {, } \\
\text { T. } 3 \mathrm{~S} \text {., R. } 9 \mathrm{~W} \text {., Yorba Linda } \\
\text { quadrangle. }\end{array}$ \\
\hline$f-5 \ldots$ & R. F. Yerkes...- & $\begin{array}{l}\text { Wall of excavation, north bank } \\
\text { of Tonner Canyon, } 1,570 \mathrm{ft} \mathrm{N} \text {. } \\
\text { and } 1,480 \mathrm{ft} \mathrm{E} \text {. of } \mathrm{SW} \text {. cor. sec. } \\
6 \text {, T. } 3 \mathrm{~S} \text {., } \mathrm{R} .9 \mathrm{~W} . \text { Yorba } \\
\text { Linda quadrangle. }\end{array}$ \\
\hline
\end{tabular}

TABLE 5.-Fossil localities in the eastern Puente Hills area-Con.

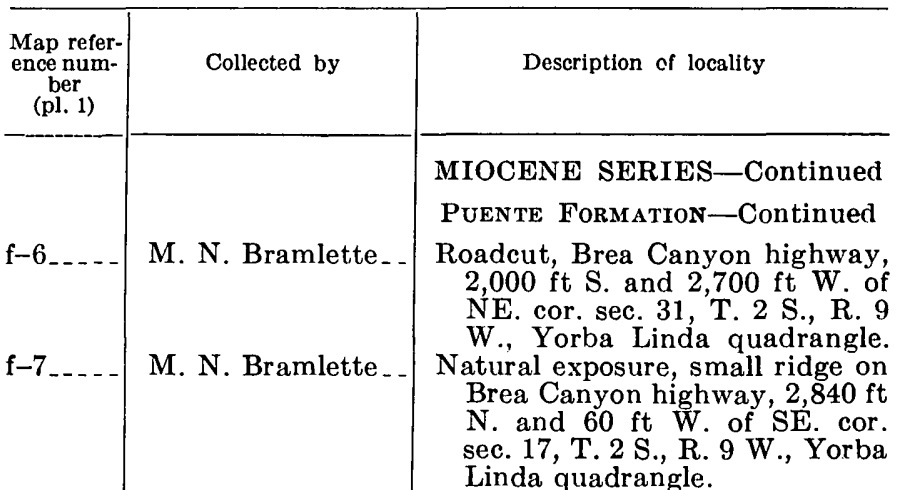
8

M. N. Bramlette Linda quadrangle.

Roadcut, Brea Canyon highway, $500 \mathrm{ft} \mathrm{N}$. and $1,475 \mathrm{ft} \mathrm{W}$. of SE. cor. sec. 17, T. 2 S., R. 9 W., Yorba Linda quadrangle.

f-9 _._. D. L. Durham _... Roadcut on ridge south of Telegraph Canyon, $490 \mathrm{ft} \mathrm{S}$. and $3,650 \mathrm{ft} \mathrm{E}$. of $\mathrm{NW}$. cor. sec. 18 , T. 3 S., R. 8 W., Yorba Linda quadrangle.

f-10_... D. L. Durham . ... Ridge south of Telegraph Canyon $1,255 \mathrm{ft} \mathrm{S}$. and $1,740 \mathrm{ft} \mathbf{E}$. of NW. cor. sec. 18 T. 3 S., R. $8 \mathrm{~W}$., Yorba Linda quadrangle.

f-11 ... R. F. Yerkes ..... . West bank of north Tonner Canyon, roadcut, $200 \mathrm{ft} \mathrm{S}$. and $2,075 \mathrm{ft} \mathrm{E}$. of $\mathrm{NW}$. cor. sec. 26, T. 2 S., R. 9 W., Yorba Linda quadrangle.

f-12... M. N. Bramlette .. East bank of north Tonner Canyon, $2,030 \mathrm{ft} \mathrm{S}$. and 2,100 ft E. of NW. cor. sec. 26, T. 2 S., R. 9 W., Yorba Linda quadrangle.

f-13_... M. N. Bramlette _. Roadcut, Brea Canyon Cutoff, $150 \mathrm{ft}$ S. and $1,400 \mathrm{ft} \mathrm{W}$. of NE. cor. sec. 30, T. 2 S., R. 9 W., Yorba Linda quadrangle.

f-14_... M. N. Bramlette _. Roadcut, Brea Canyon Cutoff, $1,300 \mathrm{ft} \mathrm{N}$. and $2,330 \mathrm{ft} \mathrm{W}$. of SE. cor. sec. 19 , T. 2 S., R. 9 W., Yorba Iinda quadrangle.

f-15_.. D. L. Durham _. . Roadcut, ridge north of Telegraph Canyon, $965 \mathrm{ft} \mathrm{S}$. and $1,525 \mathrm{ft} \mathrm{E}$. of $\mathrm{NW}$. cor. sec. 8 , T. 3 S., R. 8 W., Prado Dam quadrangle.

f-16_._. D. L. Durham _._. Roadcut, ridge north of Soquel Canyon, $1,800 \mathrm{ft} \mathrm{S}$. and $150 \mathrm{ft}$ W. of NE. cor. sec. 32 , T. 2 S., R. 8 W., Prado Dam quadrangle.

f-17 _. _ D. L. Durham _. _. Ridge southwest of Los Serranos, $1,000 \mathrm{ft} \mathrm{S}$. and $1,950 \mathrm{ft} \mathrm{W}$. of NE. cor. sec. 33, T. 2 S., R. 8 W., Prado Dam quadrangle.

f-18_... D. L. Durham .... Natural exposure, Slaughter Canyon, $850 \mathrm{ft} \mathrm{N}$. and $200 \mathrm{ft} \mathrm{E}$. of SW. cor. sec. $1, T$. 3 S., R. 8 W., Prado Dam quadrangle. f-19_... D. L. Durham _... $\quad \begin{gathered}8 \mathrm{~W} ., \text { Prado Dam quadrangle. } \\ \text { Roadcut, ridge south of Tele- }\end{gathered}$ $1,775 \mathrm{ft} \mathrm{E}$. of SW. cor. sec. 18 T. 3 S., R. 8 W., Yorba Linda quadrangle.

f-20__ D. L. Durham Pipeline ditch cut, ridge north of Santa Ana River, $4,175 \mathrm{ft} \mathrm{S}$ and $750 \mathrm{ft} \mathrm{E}$ of NW cor. sec. 20, T. 3 S., R. 8 W., Prado Dam quadrangle. 
TABLE 5.-Fossil localities in the eastern Puente Hills area-Con.

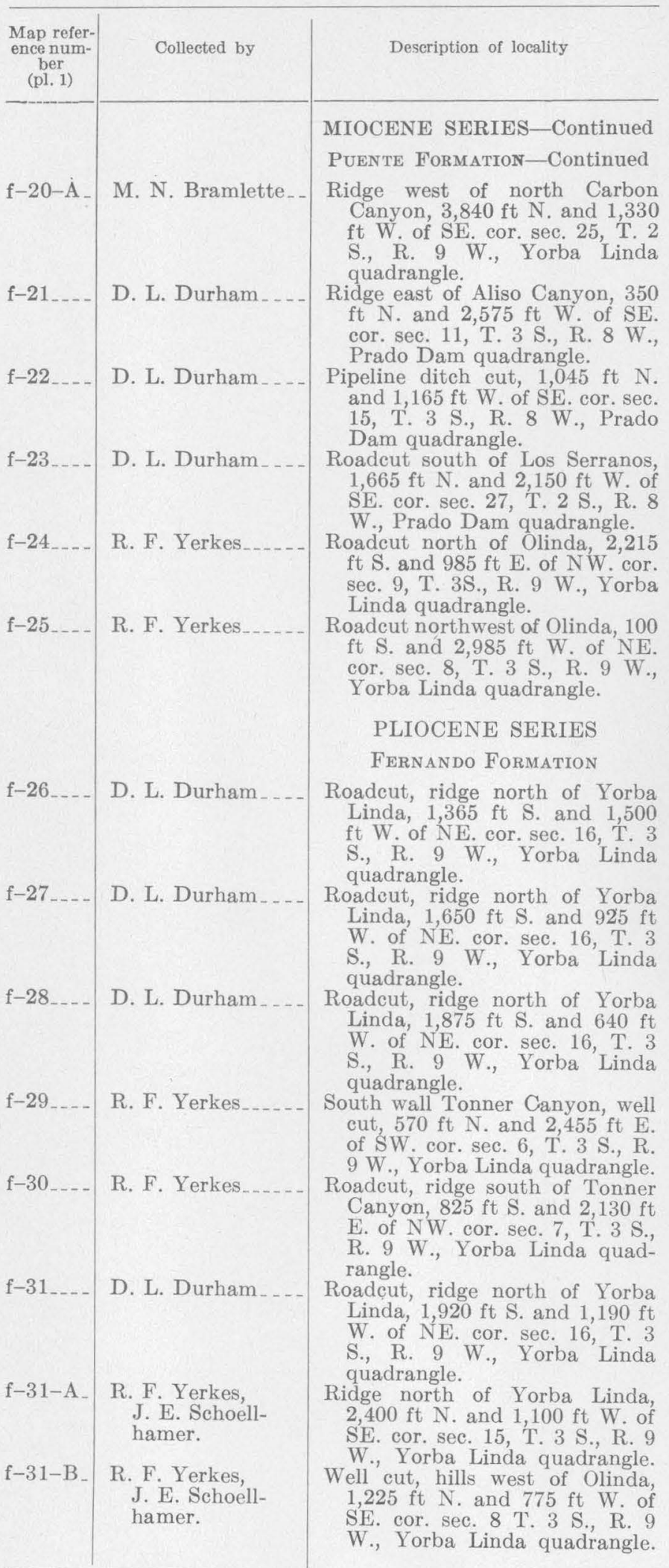

\section{SAN JUAN TUNNEL}

The San Juan tunnel is in the southwestern part of the Prado Dam quadrangle near San Juan Hill. It is part of the distribution system of the Metropolitan Water District of Southern California, which carries water from the Colorado River to the Los Angeles area. The tunnel is 6,800 feet long and the rough bore was 15 feet in diameter. The rough bore was shored up with 4 - by 12-inch eribbing laid on steel arches set about 2 feet apart. The tunnel was lined with concrete to make a finished pipeline with a circular cross section and an inside diameter of 10 feet.

The authors made weekly visits to the tunnel during its construction in 1954 and 1955 to inspect the freshly

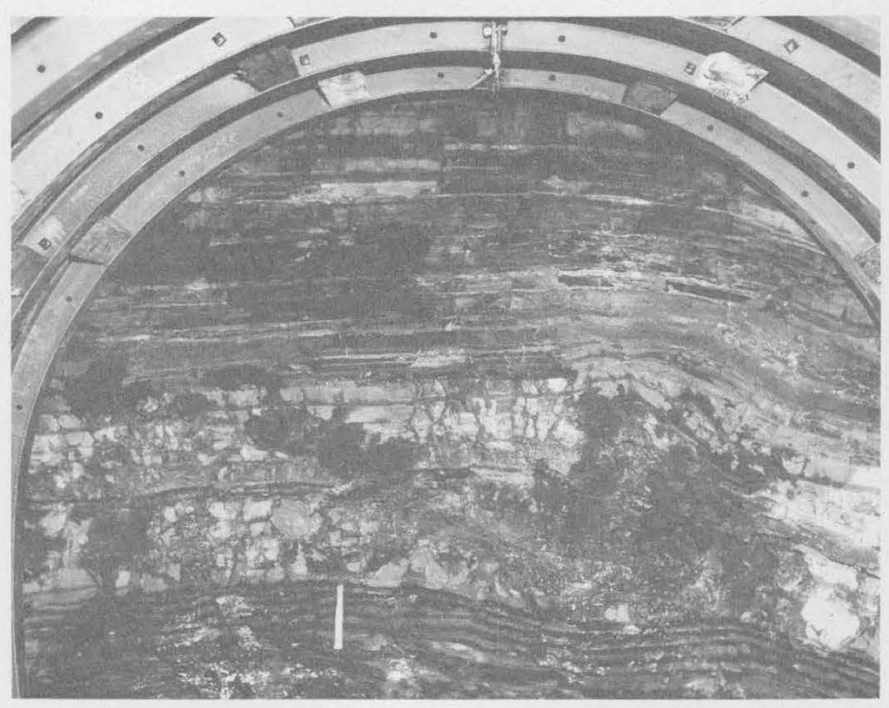

Figure 18. - Strata of the Sycamore Canyon member of the Puente formation exposed at the working face of the San Juan tunnel, 1,300 feet from the east portal.

exposed rocks (fig. 18) for structural and lithologic detail normally lost in weathered rocks at the surface. A stratigraphic thickness of about 1,100 feet in the lower part of the Sycamore Canyon member and about 760 feet in the upper part of the Yorba member of the Puente formation was penetrated by the tunnel. The contact between the Yorba and Sycamore Canyon members is exposed about 1,850 feet from the east portal of the tunnel (fig. 19). Rocks of the Sycamore Canyon member exposed in the tunnel are about 70 percent lightgray fine- to coarse-grained thick-bedded ripplemarked graded sandstone containing sedimentary structures commonly associated with turbidity current deposits (fig. 20) ; the remaining 30 percent of the rock is com- 


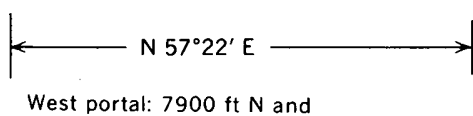

West portal: $7900 \mathrm{ft} \mathrm{N}$ and corner, Prado Dam quad. rangle

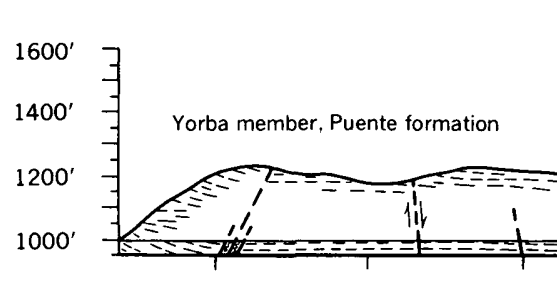

6000

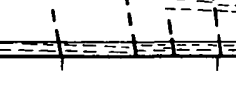

5000

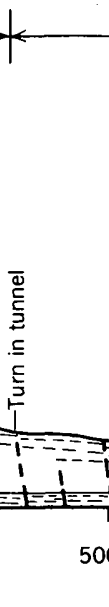

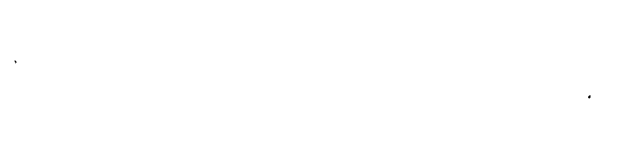


posed of dark-gray somewhat sandy siltstone occurring as laminae and thin beds as much as 2 inches thick and commonly containing well-preserved Foraminifera. The proportion of sandstone to siltstone in the Syeamore Canyon member decreases near the base. Rocks of the Yorba member exposed 2,000 feet from the east portal of the tumnel consist of 70 percent darkgray siltstone in beds as much as 1 foot thick and 30 percent light-gray to white fine- to medium-grained feldspathic sandstone in thin stringers and beds. The siltstone contains zones of brown phosphatic nodules.

Sedimentary structures such as graded bedding, cross-lamination, ripple marks, intraformational breccia, slump structures, and other features commonly associated with turbidity current deposits are conspicuous in strata exposed in the tunnel (figs. 20, 21). Scattered random measurements of directional sedimentary features indicate a general southwesterly slope of the sea bottom on which the deposits accumulated - a slope away from the postulated position of the shoreline in late Miocene time.

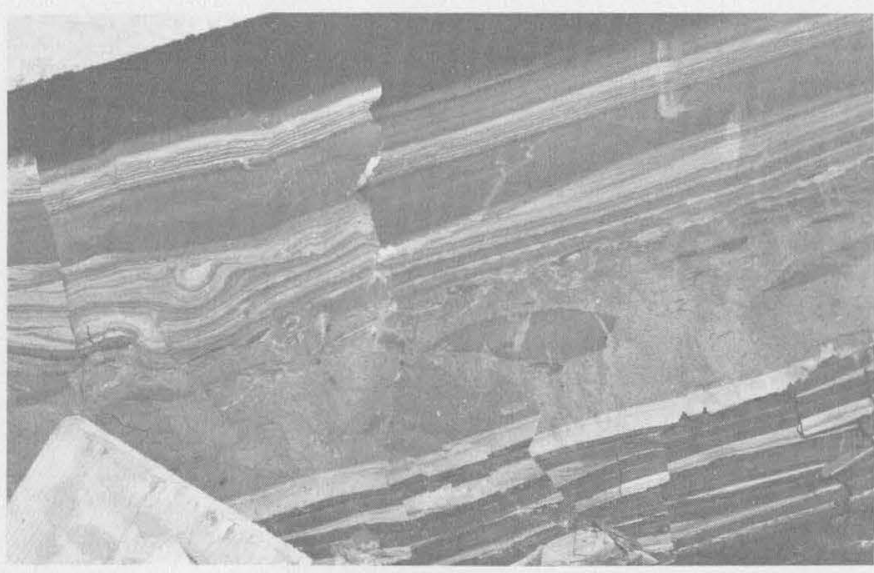

Figure 20. - Strata of the Sycamore Canyon member of the Puente formation exposed in the San Juan tunnel. The dark rock is siltstone and the lighter bands are fine- to medium-grained sandstone. The thick sandstone bed in the center contains angular fragments of dark siltstone like that in the siltstone beds below.

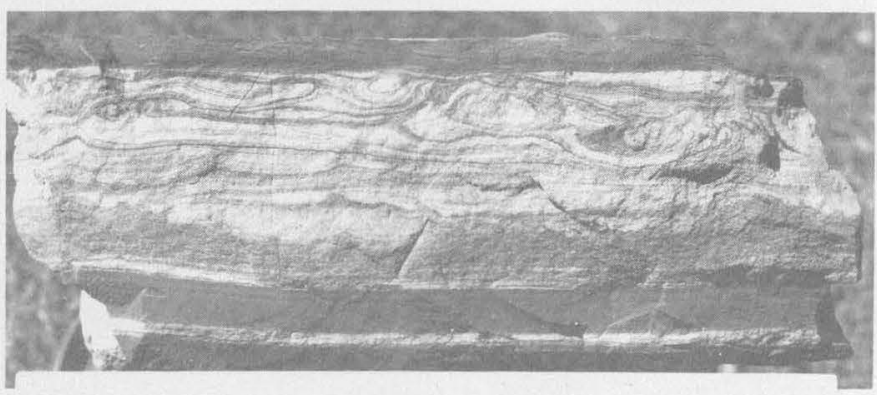

Figure 21.- Sample of interbedded siltstone and sandstone from Yorba member of the Puente formation, 3,000 feet from the east portal of the San Juan tunnel, showing bedding features typical of those exposed in the tunnel. When in place, the sample was oriented with north to the left. Scale in inches.
Sandstone stained with "dead" oil occurred in the tunnel on the upthrown side of a fault 2,322 feet from the east portal. Oil-stained sandstone with a faint petroleum odor occurred at localities 2,450, 2,508, and 2,640 feet from the east portal of the tunnel.

Many of the faults intersecting the tunnel are shear zones as much as 80 feet wide (fig. 19). In these shear zones the siltstone is commonly recemented to form a hard dense limy breccia and the sandstone is ground into a soft sandy gouge that readily permits passage of large volumes of water. Smaller faults having little or no shear zone offset beds as much as 8 feet. Relative movement on some of the larger faults was determined from the orientation of drag folds.

\section{REFERENCES CITED}

Bailey, T. S., and Jahns, R. H., 1954, Geology of the Transverse Range province, southern California, in Jahns, R. H., ed., Geology of southern California : California Div. Mines Bull. 170, chap. 2, p. 83-106.

Barger, R. M., and Gaede, V. F., 1956, Yorba Linda oil field: California Div. Oil and Gas, Summ. Operations, Ann, Rept. 42, no. 2, p. 21-25.

Benzley, J. C., 1956, Recent developments in the Yorba Linda field, in California oil and gas exploration, 1956: Los Angeles, Calif., Munger Oilogram, p. 6.

Conrey, B. L., 1958, Depositional and sedimentary patterns of lower Pliocene-Repetto rocks in the Los Angeles basin, in Higgins, J. W., ed., A guide to the geology and oil fields of the Los Angeles and Ventura regions: Los Angeles, Calif. Am. Assoc. Petroleum Geologists Pacific Sec. p. 51-54.

Conservation Committee of California Oil Producers, 1958, Annual review of California crude oil production for 1957: Los Angeles, p. 335 .

Daviess, S. N., and Woodford, A. O., 1949, Geology and structure of the northwestern Puente Hills, California: U.S. Geol. Survey Oil and Gas Inv. Prelim. Map 83.

Dickerson, R. E., 1914, The Martinez and Tejon Eocene and associated formations of the Santa Ana Mountains, California: California Univ., Dept. Geology Bull., v. 8, p. $257-270$.

Dudley, P. H., 1943, East Coyote area of the Coyote Hills oil field, in Geologic formations and economic development of the oil and gas fields of California: California Div. Mines Bull. 118, p. 349-354.

Durham, D. L., and Yerkes, R. F., 1959, Geologic map of the eastern Puente Hills, Los Angeles basin, California: V.S. Geol. Survey Oil and Gas Inv. Map OM-195.

Durham, J. W., 1954, The marine Cenozoic of southern California, in Jahns, R. H., ed., Geology of southern California : California Div. Mines Bull. 170, chap. 3 p. 23-31.

Eckis, Rollins, 1934, South coastal basin investigation, geology and ground water storage capacity of valley fill: California Div. Water Resources Bull. 45, 273 p.

Eldridge, G. H., and Arnold Ralph, 1907, The Santa Clara Valley, Puente Hills, and Los Angeles oil districts, southern California : U.S. Geol. Survey Bull. 309, 266 p.

English, W. A., 1914, The Fernando group near Newhall, California: California Univ., Dept. Geology Bull., v. 8, p. 203-218. 
English, W. A., 1926, Geology and oil resources of the Puente Hills region, southern California: U.S. Geol. Survey Bull. $768,110 \mathrm{p}$.

Gaede, V. F., and Dosch, Murray, 1955, Oil and gas development in San Bernardino County: California Div. Oil and Gas, Summ. Operations, Ann. Rept. 41, no. 2, p. 3548.

Gardiner, C. M., 1943, Richfield area of the Richfield oil field, in Geologic formations and economic development of the oil and gas fields of California: California Div. Mines Bull. 118, p. 357-360.

Hamlin, Homer, 1904, Water resources of the Salinas Valley, California: U.S. Geol. Survey Water-Supply Paper 89, 89 p.

Heath, E. G., 1958, Yorba Linda oil field, in Higgins, J. W., ed., A guide to the geology and oil fields of the Los Angeles and Ventura regions: Los Angeles, Calif. Am. Assoc. Petroleum Geologists Pacific Sec., p. 105-106.

Hill, M. L., 1954, Tectonics of faulting in southern California, in Jahns, R. H., ed., Geology of southern California: California Div. Mines Bull. 170, chap. 4, p. 5-14.

Hoots, H. W., and Bear, T. L., 1954, History of oil exploration and discovery in California, in Jahns, R. H., ed., Geology of southern California: California Div. Mines Bull. 170, chap. 9, p. 5-10.

Kew, W. S. W., 1924, Geology and oil resources of a part of Los Angeles and Ventura Counties, California : U.S. Geol. Survey Bull. 753, $202 \mathrm{p}$.

Kleinpell, R. M., 1938, Miocene stratigraphy of California: Tulsa, Okla., Am. Assoc. Petroleum Geologists, 450 p.

Krueger, M. L., 1936, The Sycamore Canyon formation, California [abs.]: Am. Assoc. Petroleum Geologists Bull., v. 20 , p. 1520.

- 1943, Chino area, in Geologic formations and economic development of the oil and gas fields of California: California Div. Mines Bull. 118, p. 362-363.

Larsen, E. S., Jr., 1948, Batholith and associated rocks of Corona, Elsinore, and San Luis Rey quadrangles, southern California : Geol. Soc. America Mem. 29, 182 p.

Larsen, E. S., Jr., Gottfried, David, Jaffe, H. W., and Waring, C. L., 1958, Lead-alpha ages of the Mesozoic batholiths of western North America: U.S. Geol. Survey Bull. 1070-B, p. 35-62.

Michelin, James, 1958, Mahala oil field, in Higgins, J. W. ed., A guide to the geology and oil fields of the Los Angeles and Ventura regions: Los Angeles, Calif. Am. Assoc. Petroleum Geologists Pacific Sec., p. 153-154.

Natland, M. L., and Rothwell, W. T., Jr., 1954, Fossil Formainifera of the Los Angeles and Ventura basins, California, in Jahns, R. H., ed., Geology of southern California : California Div. Mines Bull. 170, chap 3, p. 33-42.

Nelson, J. W., Pendleton, R. L., Dunn, J. E., Strahorn, A. T., and Watson, E. B., 1917, Soil survey of the Riverside area, California: U.S. Dept. Agriculture, Bur. Soils advance field sheets for $1915,88 \mathrm{p}$.

Norris, B. B., 1930, Report on the oil fields on or adjacent to the Whittier fault: California Div. Oil and Gas, Summ. Operations, Ann. Rept. 15, no. 4, p. 5-20.

Parker, F. S., 1943, Yorba Linda area of the Coyote Hills oil field, in Geologic formations and economic development of the oil and gas fields of California: California Div. Mines Bull. 118, p. 355 .
Post, W. S., 1928, Santa Ana investigation, flood control and conservation: California Dept. Public Works, Div. Eng. and Irrig., Bull. 19.

Reed, R. D., 1932, Section from the Repetto Hills to the Long Beach oil field, in Gale, H. S., ed., Southern California: Internat. Geol. Cong., 16th, United States 1933, Guidebook 15, p. 30-34.

Schoellhamer, J. E., Kinney, D. M., Yerkes, R. F., and Vedder J. G., 1954, Geologic map of the northern Santa Ana Mountains, Orange and Riverside Counties, California : U.S. Geol. Survey Oil and Gas Inv. Map OM-154.

Scribner, M. K., 1958, Brea Canyon area, in Higgins, J. W., ed., A guide to the geology and oil fields of the Los Angeles and Ventura regions: Los Angeles, Calif. Am. Assoc. Petroleum Geologists Pacific Sec., p. 107-108.

Sharp, R. P., 1954, Some physiographic aspects of southern California, in Jahns, R. H., ed., Geology of southern California: California Div. Mines Bull. 170, chap. 5, p. 5-10.

Shelton, J. S., 1955, Glendora volcanic rocks, Los Angeles basin, California: Geol. Soc. America Bull., v. 66, p. 45-90.

Stewart, R. E., and Stewart, K. C., 1930, "Lower Pliocene" in the eastern end of the Puente Hills, San Bernardino County, California: Am. Assoc. Petroleum Geologists Bull., v. 14, p. 1445-1450.

Stockman, L. P., 1957, California liquid hydrocarbon production, reserves: Petroleum World and Oil, Rev. no., v. 54, no. 43, p. 44-48.

Watts, W. L., 1897, Oil and gas yielding formations of Los Angeles, Ventura and Santa Barbara Counties, California : California Mining Bur. Bull. 11, 72 p.

Winterer, E. L., and Durham, D. L., 1962, Geology of southeastern Ventura basin, Los Angeles County, California: U.S. Geol. Survey Prof. Paper 334-H, p. 275-366.

Wissler, S. G., 1943, Stratigraphic formations of the producing zones of the Los Angeles basin oil fields, in Geologic formations and economic development of the oil and gas fields of California: California Div. Mines Bull. 118, p. 209-234.

1958, Correlation chart of the producing zones of Los Angeles basin oil fields, in Higgins, J. W., ed., A guide to the geology and oil fields of the Los Angeles and Ventura regions: Los Angeles, Calif. Am. Assoc. Petroleum Geologists Pacific Sec., p. 59-61.

Woodford, A. O., Moran, T. G., and Shelton, J. S., 1946, Miocene conglomerates of Puente and San Jose Hills, California : Am. Assoc. Petroleum Geologists Bull., v. 30 , p. 514-560.

Woodford, A. O., Shelton, J. S., and Moran, T. G., 1944, Geology and oil possibilities of Puente and San Jose Hills, California: U.S. Geol. Survey Oil and Gas Inv. Prelim. Map 23.

Woodford, A. O., Schoellhamer, J. E., Vedder, J. G., and Yerkes, R. F., 1954, Geology of the Los Angeles basin, in Jahns, R. H., ed., Geology of southern California: California Div. Mines Bull. 170, chap. 2, p. 65-81.

Woodring, W. P., and Popenoe, W. P., 1945, Paleocene and Eocene stratigraphy of northwestern Santa Ana Mountains, Orange County, California: U.S. Geol. Survey Oil and Gas Inv. P'relim. Chart 12.

Yerkes, R. F., 1957, Volcanic rocks of the El Modeno area, Orange County, California: U.S. Geol. Survey Prof. Paper 274-L, p. 313-334. 


\section{INDEX}

[Italic page numbers indicate major references]

A Page

Acknowlodgmonts........................ B

Aliso Canyon fault........................... 34,44

Alluvial deposits.............................. 30,32

Alluvium, older........................... $80,31,37$

older ago.

distribution and character....................

thickness.................................. 30

younger..................... si

Anahcim dome...................................... 40

Anticlincs.

Arona Blanca anticline.......................

Arona Blancr synclino

Arnold Ranch fault . ...............................

Barnaclo

Basemont rocks. depth to

Brachiopods.

. . .... 13, 19

Brea Canyon 31,35

Brea-Olinda oil field........................... 87,39

history, production, and reserves.......... 39

location and geologic features.............. 37,39

Brea-Olinda oil field area, Sycamore Canyon momber........................... 22

Bryant fault..................................... 34

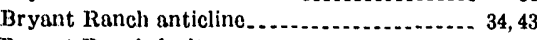

Bryant Ranch fault. . ......................... 20

Buzzard Peak conglomerate................. 10

Carbon Canyon ................................. 31

Carbon Canyon anticline...................... $\quad 34$

Carbon Canyon Creek. ....................... $\quad 29$

Chapman sand................................. 21

Chino basin.................................. $31,34,35$

depth to basement rocks. ................. 35

possible oil trap............................ 43

Chino Creck, physiography ................. 35, 36

Chino fault............ $32,34,41,43$

Chino fault zono............................ 31

Chino-Soquel oil ficld . ......................... 34 history and geologic features.............. 42 production and reserves................... 39 productive zones

Concretions. ...................... 6, 12,18,20,21

Coyote Fills uplift.................... $31,35,36,40$

Cretaccous system, plutonic rock............. 5 sedimentary rock............................

Delmontian stage.........

Diabase, in Puente and older formations.....

Dlamond Bar anticline.......................... 34

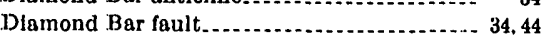

$\mathbf{E}$

East Coyote oll field history and geologic fostur................. 35, 40 production and reserves................... 39, 40 subsurface data........................... 40 topographic expression of structure ....... 36
Eastern Puente Hills, physlography .......... BS Quaternary history structural features northeast of ..........- $s /$ physiography.......................... structural features south of ................ 35

Eastern Puente Hills area, exploratory wells and selected producing ofl wells.

Physiography

Economic geology. ..............................

Elephant Hill................................. 5, 11

El Modeno volcanics.

Elsinore structural trough.

Eocene series

Erosion surface.

Esperanza oll feld, development. .............. geologic features.............................. production and reserves.

Faults, in area in San Juan tunnel............................. 59 Fernando formation................. 28, 29, 31, 39, 40 fossil localities............................. 56,57 lower member age and stratigraphic relations...-.-.-. 25 conditions of deposition................ 26 distribution and character............. 25 foraminifera....................... 15, 17 cossils oll productivity ........................ 42 relation to Whittier fault zone......... 25 thickness................................ 25

nomenclature.................. 24 oil produced from ............................. 42 tar seeps........................................ upper member, age and stratigraphlc relations............................. distribution and character

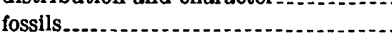
thickness

Fieldwork

Fish scales

Folds in report area. $7,12,13,14,15,16,17,19,20,21,22,24,25,26$ identified by Patsy B. Smith............ 5, 14, 20 in San Juan tunnel...................... 59 stratigraphic distribution .................. 14

Foraminifera from Puente and Fernando formations, alphabetic key to genera and species in area........

stratigraphic distribution in area

Fossil localities

in eastern Puente Hills area............... $\quad 66$

Fossils. See under names of orders and of formations.

Fossils identified . .......... 5-10, 12-17, 19-22, 24-26

G

Gastropods........................... 9, 25, 26, 27

Glendora volcanics................................. 11

Graded beds............................. 18, 19, 23, 59

Granitic basement rocks..................... 6
H

Page

Horseshoe Bend........................ B9, 31, 42 Horseshoe Bend area, physiography ......... Horseshoe Bend fault..............

L

Ladd formation of Late Cretaceous age ........

La Habra formation .

age and stratigraphic relations............ 28 conditions of deposition...................... 29

distribution and character................ 28

stratigraphic section....................... 28

thickness................................ 29

La Habra syncline............. 31, 35, 40

Los Angeles basin ................................ 34

structural evolution.......................

U.S. Geological Survey's investigation.... 3

Los Angeles (Downey) Plain................

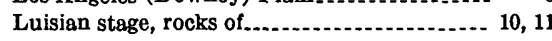

$\mathbf{M}$

Mahala anticline, future development......... 34, 43

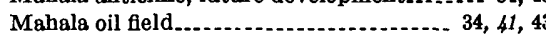
geologic features.......................... 41,42

history

possible extension. 43

Megafossils............................ 25

Metropolitan Water District of Southern California, aqueduct..............-.

Miocene series, fossil localities................. 56

Mohnian stage............................. 10, 13, 24

foraminifera of

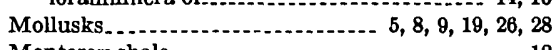

Monterey shale...............................

Oil development, exploratory wells............ 44 outlook for future.

Oil fields, Brea-Olinda

S7

Esperanza................................. 41

history

Mahala ............................................

production statistics..................... 37,39

reports on.................................. 37

Richfield ........................... 8, 11, 20, 21, 39

Yorba Linda................................ 40

Oil occurrence, summary .................... 48

Oll sand.......................................... 59

Oil traces in San Juan tunnel............... 59

Onl wells, exploratory and selected producing. subsurface data from

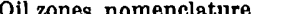

Oil-producing zones in are

Oil-stained sandstone.........................

Olinda area

upper member of Fernando formation

Paleocene series.

Parris block

Pelecypods. 


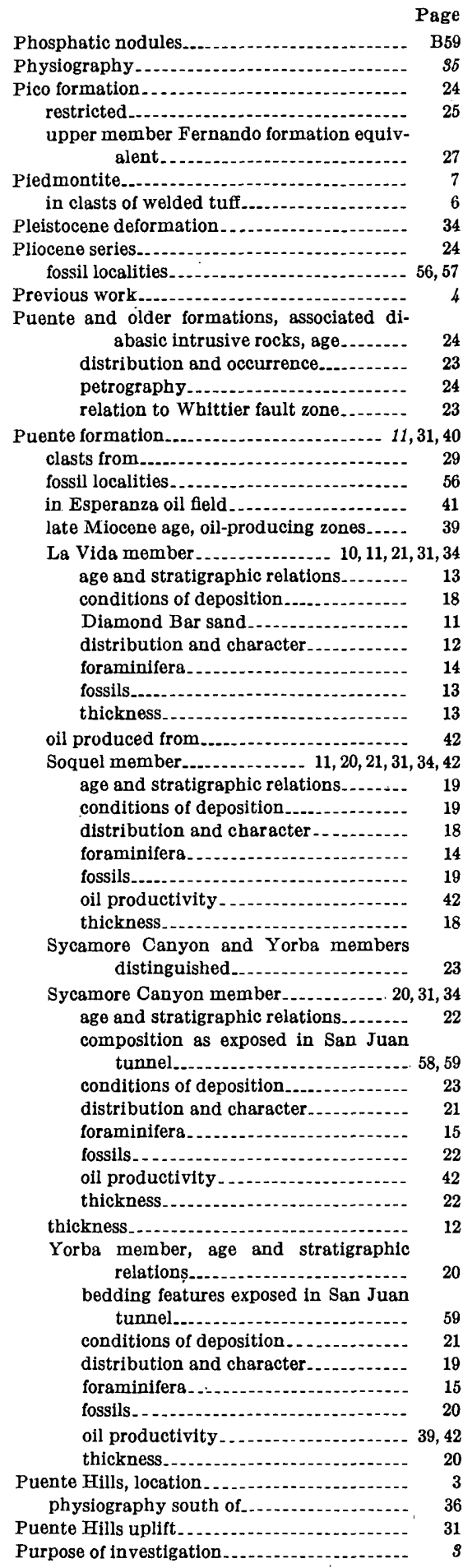

Q

Quaternary system, Pleistocene series........ B28 Pleistocene to recent series................ 30

$\mathbf{R}$

Red beds...

References cited

Repetto formation

abandoned

Repetto Hills, Monterey Pass

Richfleld oil-field area........................

Richfield oil fields, geologic features.......... $s 9,4$

history, production and reserves...........

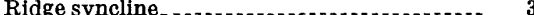

San Bernardino Valley.

San Gabriel Valley

San Juan tunnel

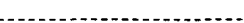

subsurface data from

Sycamore Canyon member...............

Santa Ana Mountains, Upper Cretaceous strata.

Santa Ana River

physiography .

Santa Ana River canyon.

Santa Fe Springs, oil field, topographic ex-$$
\text { pression. }
$$

Santiago form

Santiago Peak volcanics of Jurassic age ......

Scaphopods.

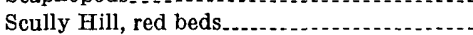

Scully Hill area, possible oil trap.

Topanga formation...............

Scully Hill fault

Sedimentary rocks of area, thickness...........

Sedimentary structures

in San Juan tunnel

Sespe formation. See Vaqueros and Sespe formations undifferentiated.

Silverado formation .......................

Slaughter Canyon, Sycamore Canyon mem-

$$
\text { ber }
$$

Smith, Patsy B., fossils identified by ........ 14, 20

Soquel Canyon anticline-.........................

Southern California batholith, age................

Stratigraphy

Streams, entrenchment of $\ldots \ldots \ldots . . .35,36,37$

Structural features, Arena Blanca syncline.... Chino fault.

Horseshoe Bend fault

Mahala anticline

northeast of the eastern Puente Hills...-

north of the Whittier fault zone and west of the Chino fault, faults..........

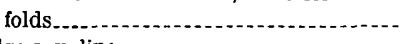

Ridge syncline................................. 20, 21

setting.......................................... 31

south of the eastern Puente Hills........

Whittier fault zone

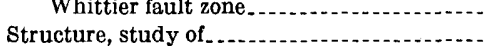

Tar sand 1 Tegraph Ganyon.
Page

Telegraph Canyon anticline................... B34

Tertiary System, Eocene Series................ 6

Middle Miocene series.................... 8,11

Paleocene Series............................ 6

Pliocene Series............................. 24

Upper Eocene to Lower Miocene Series.... 7,8

Tonner Canyon area................ 26, 28, 29, 31, 35 lower member of Fernando formation..... 25 oil production ........................... 39

Topanga formation...................... $8,10,11,31$ age and stratigraphic relations............. associated volcanic rocks, age and correlation..

distribution and stratigraphic relations. petrography

conditions of deposition

Diamond Bar sand, age and stratigraphic relations.

conditions of deposition

distribution and character.................

thickness. . . . . . . . . .

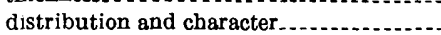

fossil localities.

fossils.

thictoness

Tuff beds, in La Vida member. ..................

Turbidity currents.

deposits from

part in deposition of Soquel member......

$\mathbf{U}$

Upper Miocene Series.

V

Vaqueros and Sespe formations undifferentiated, age and stratigraphic relations.

distribution and character................

structure

thickness.....................................

Vedder, J. G., mollusks identified by ... .. 5, $9,25,26$

W

Welded tuff.

W

Wells, exploratory...

Wells, exploratory

topographic expression of structure...... 36

Whittier fault zone...................... 4, 31, 34, 35 diabasic intrusives........................... 23

dominant structure in

physiography............................. 37

structural features south of $\ldots$

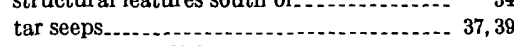

Wireline Canyon, diabase.

\section{$\mathrm{Y}$$$
\mathrm{Y}
$$

Yorba Linda

Yorbe Linda area, Le Habra formation

Yorba Linda oil field, geologic features and productive zones............. 40,41

history

production and reserves

Yorba-Sycamore Canyon members, contact in San Juan tunnel

1

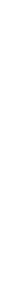

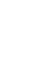

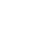

